\title{
Leveraged Liquidity: Bear Raids and Junk Loans in the New Credit Market
}

Jose M. Gabilondo

College of Law, Florida International University, jose.gabilondo@fiu.edu

Follow this and additional works at: https://ecollections.law.fiu.edu/faculty_publications

Part of the Antitrust and Trade Regulation Commons, Banking and Finance Law Commons, and the Business Organizations Law Commons

\section{Recommended Citation}

Jose M. Gabilondo, Leveraged Liquidity: Bear Raids and Junk Loans in the New Credit Market, 34 J. Corp. L. 447 (2009).

Available at: https://ecollections.law.fiu.edu/faculty_publications/84 


\section{HEINONLINE}

Citation: 34 J. Corp. L. 447 2008-2009

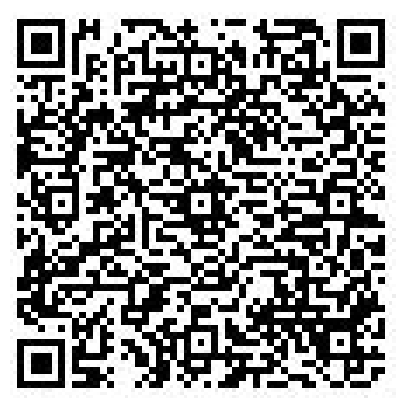

Content downloaded/printed from

HeinOnline (http://heinonline.org)

Fri Nov 14 18:57:07 2014

-- Your use of this HeinOnline PDF indicates your acceptance of HeinOnline's Terms and Conditions of the license agreement available at http://heinonline.org/HOL/License

-- The search text of this PDF is generated from uncorrected OCR text.

-- To obtain permission to use this article beyond the scope of your HeinOnline license, please use:

https://www.copyright.com/ccc/basicSearch.do?

\&operation $=$ go\&search Type $=0$

\&lastSearch $=$ simple\&all=on\&titleOrStdNo=0360-795X 


\title{
Leveraged Liquidity: Bear Raids and Junk Loans in the New Credit Market
}

\author{
José Gabilondo*
}

I. INTRODUCTION 448

II. A LiQUidiTY ACCOUNT OF CORPORATE LEVERAGE MARKETS ................................ 454

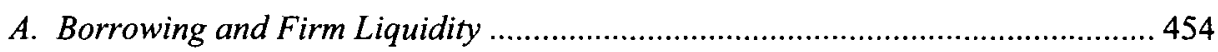

B. Secondary Market Liquidity and Its Links to Borrower Liquidity ...................... 456

C. The Summer 2007 Market Break in Liquidity.................................................... 460

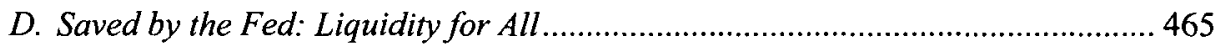

III. LEVERAGE AND LIQUIDITY LOOPS IN THE FINANCIAL SECTOR ................................ 467

A. Minsky: The Ongoing Relevance of Liability Financing .................................. 468

B. Market Structure Shifts Towards Ponzi Finance ……...................................... 476

1. Desensitization to Leverage ……………………….................................... 477

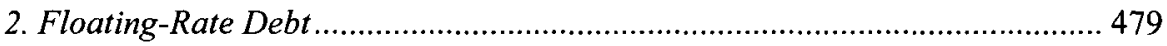

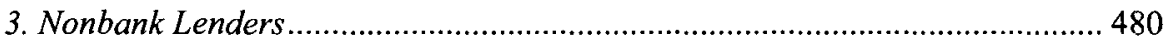

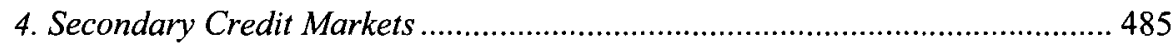

C. The Revival of Financial Cycle Theory ......................................................... 488

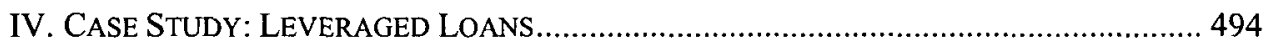

A. Instrument and Market Structure ................................................................... 494

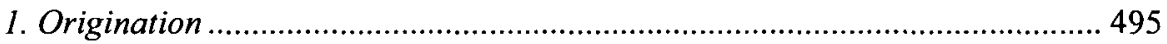

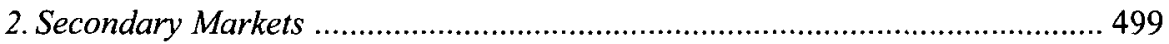

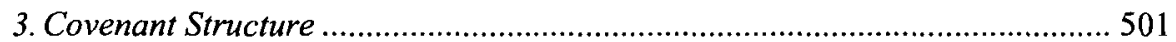

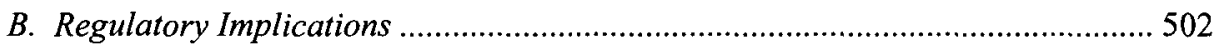

V. MODELING LEVERAGED LIQUIDITY................................................................. 504

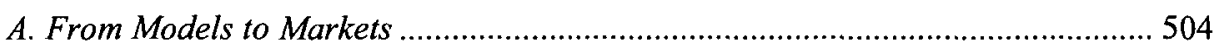

B. Internalizing Extreme Liquidity Events Into Risk Management (and Then

* José Gabilondo, Associate Professor, Raphael Diaz-Balart Hall, College of Law, Florida International University, Miami, Florida 33139, jose.gabilondo@fiu.edu. A.B., Harvard College, 1987; J.D., University of California (Boalt Hall), Berkeley, 1991. This Article benefited from feedback received at the May 2007 meeting of the Latin American and Caribbean Law and Economics Association, the 2007 Stetson Junior Faculty Retreat, and faculty colloquia at the University of Buffalo Law School and the Florida International University College of Law. My grateful thanks go to Charles Pouncy, ¡Schlegel!, Bill Bratton, Lissa Broome, Jerry Markham, Felice Batlan, George Mundstock, Bert Westbrook, and Russ Powell for their comments on earlier drafts. 


\section{INTRODUCTION}

By now, we have all noticed the turbulence in our credit market. Defaults on residential mortgages have climbed, prices for structured credit products have fallen, and banks have tightened lending standards. To counter some of this, the Federal Reserve (Fed) has been adding "liquidity" to the credit system by lending banks cash (or financial resources that act like cash) against collateral pledged by the banks. ${ }^{1}$ Liquidity injections reassure nervous banks and, it is hoped, coax them into making loans of their own to consumers and businesses, that way jump-starting confidence in the economy. One such liquidity tool is the Fed's discount window, which lets a bank pledge its own loans to bank customers (or securities from the bank's own portfolio) in exchange for a cash loan from the Fed. ${ }^{2}$ Think of it as the Fed's pawnshop for commercial banks facing short-term liquidity problems.

During the discount window's near-century of operations, only depository institutions like commercial banks could use it, with the exception of some nonbank firms that got emergency loans in the Great Depression. ${ }^{3}$ But in March 2008, the New York Federal Reserve Bank agreed to use discount window liquidity for the benefit of Bear Stearns (Bear), an investment bank, using JPMorgan Chase \& Co. (JP Morgan), a depository institution that is a member of the Fed, as a financing conduit. ${ }^{4}$ The loan was used to fund JP Morgan's acquisition of Bear, for which JP Morgan put in \$1 billion and the Fed lent $\$ 29$ billion through the discount window at terms that are much more borrower-friendly than typical discount window lending. ${ }^{5}$ In the words of the New York

1. Press Release, Fed. Reserve (Mar, 11, 2008), available at http://www.federalreserve.gov/newsevents/ press/monetary/20080311a.htm. Most recently, the Fed did this by increasing the term of its securities lending facility from overnight to 28 days and by increasing the dollar amount of the facility. Id. The previous week, the Fed had also increased the dollar amount of a special auction facility and begun a series of open market transactions, both designed to add liquidity. Id. These actions supplemented the Fed's recent steps of lowering the discount rate and the targeted rate for the inter-bank Federal Funds market. Id.

2. David L. Mengle, The Discount Window, in INSTRUMENTS OF THE MONEY MARKET 22, 26 (Timothy Q. Cook \& Robert K. LaRoche eds., 1993) (“Appropriate uses of discount window adjustment credit include meeting demands for funds due to unexpected withdrawals of deposits, avoiding overdrafts in reserve accounts caused by unexpected financial flows, and providing liquidity in case of computer failures, natural disasters, and other forces beyond an institution's control." (citation omitted)).

3. Federal Reserve Act of $1913 \S 13(3), 38$ Stat. 263 (current version at 12 U.S.C. $\S 343(2000)$ ). The original Federal Reserve Act (Act) provided access to central bank liquidity only to member banks of the Federal Reserve and prohibited a member bank's use of the discount window even for the benefit of nonmember banks. BD. OF GOVERNORS OF THE FED. RESERVE SYS., LENDING FUNCTIONS OF FEDERAL RESERVE BANKS: A HISTORY 118 (1973) [hereinafter FEDERAL RESERVE LENDING HISTORY]. When credit contracted during the Depression, Congress amended the Act in 1932 to allow the central bank to provide emergency credit to individuals, partnerships, and corporations. See id. at 127-29 (analyzing the legislative history of the 1932 amendment providing emergency authority). Between 1932 and 1936, the Federal Reserve used the emergency authority to loan about $\$ 1.5$ million to 123 business enterprises, of which the largest loan was $\$ 300,000$. Id. at 130 .

4. Kate Kelly et al,, Fed Races to Rescue Bear Stearns in Bid to Steady Financial System, WALL ST. J., Mar. 15, 2008, at Al.

5. It is a floating-rate, nonrecourse loan at the (collateralized) discount window rate, which was then 
Fed, the action was being taken "with the support of the [U.S.] Treasury Department, to bolster market liquidity and promote orderly market functioning."6 JP Morgan finalized the acquisition of Bear in a stock-for-stock merger that became effective in May 2008. ${ }^{7}$

Legal authority for the deal with Bear (aptly named since "bear" means downward price pressure) came from a section of the Federal Reserve Act that lets a majority of Fed governors extend emergency credit to individuals and firms in "unusual and exigent circumstances," as they had in the $1930 \mathrm{~s}^{8}$ The use of Fed liquidity to keep an investment bank viable is significant, as noted by the senior Fed official in charge of the loan when testifying about it to the Senate Banking Committee. ${ }^{9}$ No isolated transaction, the Bear deal is part of an evolving response on the part of regulators to a new credit market. Just two weeks after the deal, the U.S. Department of the Treasury proposed a new approach to financial market regulation-the Treasury Blueprint for a Modernized Financial Regulatory Structure (Treasury Blueprint).$^{10}$ By recommending that the Federal Reserve had a legitimate interest in providing emergency financing to institutions other than depository institutions, the Treasury Blueprint blessed the Bear deal and endorsed access to the discount window for financial firms other than banks. " This too is noteworthy.

The Bear deal is a watershed in U.S. banking and finance because it marks the official recognition that new liquidity dynamics in our credit markets merit attention. Indeed, liquidity is the financial dimension of the hour. As the Chairman of the U.S. Securities and Exchange Commission (SEC) emphasized about Bear, it was "a loss of

about 2.5\%. Press Release, Fed. Reserve Bank of N.Y., Summary of Terms and Conditions Regarding the JP Morgan Chase Facility (Mar. 24, 2008) (on file with author). Unless the New York Fed elects otherwise, no payment is due on the loan during its first two years. Id. Discount lending is usually fully recourse against the borrower in order to protect the Federal Reserve's interest as a lender. See generally Extensions of Credit by Federal Reserve Banks (Regulation A), 12 C.F.R. $\$ 201$ (2008); see also The Federal Reserve System Guide to Discount Window Collateral, http://www.frbdiscountwindow.org/frscollateralguide.cfm?hdrID

$=21$ \&dtlID=81 (last visited Jan. 2i, 2009).

6. Press Release, Fed. Reserve Bank of N.Y., Statement of Financing Arrangement of J.P. Morgan Chase's Acquisition of Bear Stearns (Mar. 24, 2008) (on file with author).

7. Press Release, JPMorgan Chase \& Co., JPMorgan Chase Completes Bear Stearns Acquisition (May 31,2008 ) (on file with author). It took several weeks to satisfy the conditions precedent for the merger. AGREEMENT AND PLAN OF MERGER BY AND BETWEEN THE BEAR STEARNS COMPANIES INC. AND JPMORGAN CHASE \& CO. 32-34 (2008), available at http://lawprofessors.typepad.com/mergers/files/bsmerger_2.pdf (itemizing conditions precedent).

8. FEDERAL RESERVE LENDING HISTORY, supra note 3, at 128.

9. Timothy F. Geithner, President \& C.E.O., Fed. Reserve Bank of N.Y., Statement Before the U.S. Senate Committee on Banking, Housing, and Urban Affairs Regarding Actions Taken by the Federal Reserve Bank of New York Taken in Response to Liquidity Pressures in Financial Markets 13 (Apr. 3, 2008) [hereinafter Geithner Statement], available at http://banking.senate.gov/public/_files/OpgStmtGeithner4308 Testimony.pdf ("We recognized . . . that the use of this legal authority was . . . an extraordinary step. At the same time, we were mindful that Congress included this lending power in the Federal Reserve Act for a reason, and it seemed irresponsible for us not to use that authority in this unique situation.").

10. DEP'T OF THE TREASURY, DEPARTMENT OF THE TREASURY BLUEPRINT FOR A MODERNIZED FINANCIAL REGULATORY STRUCTURE (2008) [hereinafter TREASURY BLUEPRINT]

11. Id. at 17 ("In addition, the Federal Reserve should have the ability to undertake market stability discount window lending. Such lending would expand the Federal Reserve's lender of last resort function to include non-FIDIs [financial institutions other than depository institutions]."); see also id. at 155-56 (arguing that the Fed should act as lender of last resort to firms other than depository institutions if doing so promotes "market stability"). 
liquidity - not inadequate capital-[that] caused Bear's demise."12 Liquidity "feeds fantasies that risk has evaporated. ... Just as inflation shaped psychologies a generation ago, liquidity determines our behavior in a world of short-term performance."13 Unfortunately, our understanding of liquidity has not kept pace with the credit market, hence much discussion of the issue is imprecise or incomplete. ${ }^{14}$ These liquidity dynamics are here to stay, so the sooner regulators and traders face up to them, the better. Luckily, financial academics and regulators concerned with liquidity are working on new conceptual tools, including this Article. ${ }^{15}$ To that end, I offer an analytic framework (accessible to the nonfinancial reader) for understanding the liquidity dynamics of the new credit market that led to the Bear deal. The Article has four major parts: a liquidity analysis of the corporate leverage market (Part II), a theoretical framework for these dynamics (Part III), a case study that illustrates these dynamics (Part IV), and recommendations (Part V).

Part II offers a state-of-the-art liquidity account of the corporate leverage market that introduces lay readers to the Article's concept base. I start by distinguishing between borrower and market liquidity. A liquid borrower is one that can meet its debt obligations as they come due. Here, liquidity is not the same as solvency since a borrower that is bankrupt can be liquid, insofar as it has cash on hand to meet maturing liabilities. Conversely, a solvent borrower can be illiquid if its current debts exceed its cash and credit, so-called "equitable insolvency." For example, Bear's ample capital could not stave off its liquidity crisis. ${ }^{16}$ Moving from the liquidity of a firm to that of a market, an asset market is said to be liquid when an asset can be quickly disposed of at its expected value.

With this distinction in place, I then assert three interrelated axioms about the links between a firm's borrowing, the firm's liquidity, and market liquidity, links that have become increasingly apparent thanks to secondary markets for credit products. First, a firm can enhance its own liquidity by drawing on the market liquidity of its assets in their secondary market. Second, turning from the left- to the right-hand side of a firm's balance sheet, frothy liquidity in the secondary market for a firm's liabilities may not be a proxy for the firm's liquidity or, even, the credit quality of the liability because a borrower can become less liquid as trading in its liabilities becomes more liquid. Third,

12. Letter from Christopher Cox, Chairman, Sec. \& Exch. Comm'n, to Dr. Nout Wellink, Chairman, Basel Comm. on Banking Supervision 1 (Mar. 20, 2008) [hereinafter Cox Letter] (on file with author) (emphasizing the importance of liquidity management during market downturns).

13. Robert Teitelman, Transactions, DEAL, Dec. 3, 2007, at 10.

14. See Tobias adrian \& HyUn Song ShIN, Fed. Reserve Bank of N.Y. Staff Report No. 328 , LIQUIDITY AND LEVERAGE 3 (2008), available at http://www.newyorkfed.org/research/staff_reports/sr328.pdf (criticizing financial commentary about "'excess liquidity' in the financial system" and "financial markets being 'awash with liquidity,' or liquidity 'sloshing around"' because "the precise sense in which 'liquidity' is being used in such contexts is often left unspecified").

15. The single most comprehensive example (although it is short on legal implications) is a recent special issue of Financial Stability Review, a periodical on liquidity published by the Banque de France. See Special Issue, Liquidity, Fin. STABILITY Rev., Feb. 2008, at 1; see also Frank Partnoy \& David A. Skeel, Jr., Debt as a Lever of Control: The Promise and Perils of Credit Derivatives, 75 U. CN. L. REv. 1019, 1051 (2007) (explaining how credit derivatives are "transforming the landscape of corporate governance").

16. See Cox Letter, supra note 12, at 1 ('[E]ven at the time of its sale on Sunday, Bear Stearns' capital, and its broker-dealers' capital, exceeded supervisory standards. Counterparty withdrawals and credit denials, resulting in a loss of liquidity—not inadequate capital-caused Bear's demise."). 
insofar as a firm borrows to buy financial assets, that firm's decision to shore up its own liquidity by borrowing less (or a lender's decision to cut credit to the firm) can reduce the market liquidity of these financial assets, thereby increasing the liquidity risk of another firm that had counted on selling them. In other words, both borrower liquidity and market liquidity may themselves be "leveraged" insofar as either rests on layered borrowing, whose terms may presume unsustainable increases in asset values and trading volume. When the escalation stops, so too do the liquidities of firms and markets. And then the losses and introspection begin. So it is not only an "Age of Leverage"17 but, rather, one of leveraged liquidity in which the mutually reinforcing dynamics between leverage and liquidity came into plain view. Not tulips, but periods of financial euphorias do share certain elements, including the tendency to reflect about volatility and loss after the fact and to revisit core assumptions about financial markets. ${ }^{18}$

Part III expands on the concept of leveraged liquidity by applying economist Hyman Minsky's analysis of how borrowing leads to financial fragility that can resolve, eventually, into financial instability. ${ }^{19}$ A post-Depression academic, Minsky has important things to teach us about our current credit market, including about not properly heeding the risks of financial innovation, a point made in a recent New Yorker article about him. ${ }^{20} \mathrm{He}$ wanted to strengthen capitalist economies, like ours, by stabilizing the economy - a goal echoed by many facing the current round of congressional inquiries into the economy. ${ }^{21} \mathrm{~A}$ proper appreciation of leverage cycles and their liquidity dynamics has been somewhat obscured by a culture of "financial innovation" that benignly frames the risk from new financing arrangements in terms of "entrepreneurial imagination" and a "general fascination with novelty." 22 This cultural paradigm rests on the idea that

17. The phrase belongs to Wall Street Journal writer George Anders. See GEORGE ANDERS, MERCHANTS OF DEBT: KKR AND THE MORTGAGING OF AMERICAN BUSINESS, at xx (1992) ("But in every capitalist boom, the most frenzied period comes just before the crash. .. The Age of Leverage in late 1989 and early 1990 came to a cataclysmic halt as well.").

18. Bevis Longstreth, The SEC After Fifty Years: An Assessment of Its Past and Future, 83 COLUM. L. REV. 1593, 1597 (1983) (reviewing JOEL SELIGMAN, THE TRANSFORMATION OF WALL STREET: A HISTORY OF THE SECURITIES AND EXCHANGE COMMISSION AND MODERN CORPORATE FINANCE (1982)) ("For [securities] legislation to pass, a crisis, scandal or other dramatic event was required to open a 'window of opportunity,' through which it was possible for the Commission or other advocates of reform to move the Congress to action.").

19. Legal scholarship has cited him generally for his thesis about financial instability. See Frank Partnoy, Why Markets Crash and What Law Can Do About $l t, 61$ U. PITT. L. REV. 741, 755-56 (2000) (identifying Minsky's financial instability thesis as a precursor to Charles Kindleberger's economic history of financial market crashes). Partnoy situates Minsky as a source of economic arguments that financial markets crash because of "cognitive error" on the part of individual borrowers and lenders in the market. Id. at 754-55. I focus on the liquidity implications of how Minsky classified borrowing. See infra notes 106-12 and accompanying text (explaining Minsky's financial instability thesis and its application to Bear Stearns).

20. John Cassidy, The Minsky Moment, NEw YORKER, Feb. 4, 2008, at 19, available at http://www.newyorker.com/talk/comment/2008/02/04/080204taco_talk_cassidy ("Many of Minsky's colleagues regarded his 'financial-instability hypothesis,' which he first developed in the nineteen-sixties, as radical if not crackpot. Today, with the subprime crisis seemingly on the verge of metamorphosing . . Minsky's hypothesis is well worth revisiting.").

21. See, e.g., Geithner Statement, supra note 9, at 19 ("In addition to a stronger set of protections for consumers, the overwhelming imperative of reform must be to put in place a stronger framework for financial stability.").

22. See Charles R.P. Pouncy, Contemporary Financial Innovation: Orthodoxy and Alternatives, 51 SMU 
financial innovation obeys the irreversible path of progress associated with the development of the natural sciences or new technology. ${ }^{23}$ Minsky offers a critical account of such innovation that is timely and useful.

An interpreter of John Maynard Keynes's arguments about liquidity and the centrality of the financial sector, Minsky contributed to the Post-Keynesian theory that flowered during the reconstruction of financial markets after World War II. Trained at Harvard under economic historian Joseph Schumpeter, Minsky observed that "[i]t turns out that the fundamental instability of a capitalist economy is the tendency to explodeto enter into a boom or 'euphoric' state," followed by a bust. ${ }^{24}$ Few would deny that we are now in a bust state, although whether or not we were in a boom state as prices rose was a contentious claim, especially for growth boosters and financial promoters. Although classified as a "radical" post-Keynesian, his insights seem mild (though valuable) and, frankly, hard to resist. Most mainstream economists, regulators, and policy makers avoid mention of Minsky (to his credit, though, the former Treasury Undersecretary for Domestic Finance recently endorsed Minsky's framework for cycles), but his analysis, models, and language haunt the present. ${ }^{25}$

Minsky emphasized the role of firms that borrow to lend (financial intermediaries) in these cycles, particularly the tendency of these firms to borrow at increasingly risky terms that become unsustainable, producing financial fragility that eventually resolves into a financial crisis. ${ }^{26}$ His hunch about understanding financial instability was "follow the corporate liabilities," especially those issued by firms that borrow to lend. Four trends in the credit market give credence to his hunch: the increased acceptance of leverage as a fact of business life, more corporate borrowing at floating-rates, the growth of nonbank

L. REV. 505, 509 (1998). Pouncy notes that attributing financial innovation solely to classical conceptions of supply and demand does not tell the whole story: "Legal scholarship has not produced critical examinations of financial innovation as an economic process. . . Legal scholarship assumes that both processes are the natural result of bursts of entrepreneurial creativity. It further assumes that these processes arise in response to consumer demand. . . . The products generated are readily accepted and adjudged good." $I d$. at 508 (citation omitted).

23. Not seeing how the same financial risk of loss can take different instrument forms in different periods is one effect, as Pouncy points out, of thinking of financial innovation as a form of progress: "Our confidence in our understanding of financial innovation is based on the assumption that financial innovation is similar to the process of technological innovation. Legal scholarship assumes that both processes are the natural result of bursts of entrepreneurial creativity." Id. (citation omitted).

24. HyMAN P. MinSKY, CAN "IT" HAPPEN AgaIn? ESSAYS ON INSTABILITY AND FinANCE 118 (1982) [hereinafter MINSKY, CAN IT?].

25. Former Treasury Undersecretary Robert Steel (now Chairman of Wachovia) endorsed Minsky's framework as a way to understand the cyclical dynamics of the current credit crisis. Robert K. Steel, Treasury Undersecretary, Speech to the Society of American Business Editors and Writers Annual Conference (Apr. 28, 2008). Much of this Article explains the ongoing relevance of Minsky's theory to the current policy debates. Some examples are the persistence of financial cycles, see infra Part III.C, focus on financial stability, see infra Part III.A, the centrality of the financial sector, see infra Part III.A, the need to move beyond the banking model, see infra Part III.B.3, and structural biases in the financial economy towards speculative and Ponzi debt, see infra Part III.B.

26. Economist Nouriel Roubini has noted on his website that Minsky's model does a good job of explaining the 1980s savings and loans bubble and 1990s tech bubble and that "the experiences of the last few years suggest another Minsky Credit Cycle that has probably now reached its peak." Nouriel Roubini, Are We at the Peak of a Minsky Credit Cycle?, RGE MONITOR, July 30, 2007, http://www.rgemonitor.com/blog/ roubini/208166. 
firms as both lenders and credit traders, and the role of secondary credit markets. ${ }^{27}$ These are the trends that are leading regulators and politicians to consider financial reform, so I analyze each one and its contribution to the liquidity axioms from Part II.

Telescoping in on a new asset class that emerged during the last corporate leverage wave, Part IV offers a case study of a corporate liability that epitomizes Minsky's concerns and illustrates the four trends toward financial fragility-leveraged loans. Not surprisingly, Fed officials have linked these loans to the recent credit turbulence. ${ }^{28} \mathrm{~A}$ prism into the corporate leverage market, these are high-risk, floating-rate loans arranged by banks, syndicated through nonbank lenders like pension, hedge, and private equity funds, and used to finance leveraged restructuring. Imagine the corporate equivalent of subprime mortgages, as suggested by the International Monetary Fund (IMF) given that both subprime mortgages and leveraged loans tend to be priced off the same interest rate. ${ }^{29}$ Some have defended leveraged loans from the "junk" moniker. ${ }^{30}$ I do not, although in finance "junk" is no slur: it is just the proper name for a high-risk, high-return asset class. Like the junk bonds of the 1980s, leveraged loans are subinvestment grade but, unlike junk bonds, they are issued at a floating rate, tend to carry nominal forms of junior lien security, and can be repaid by the borrower more easily. ${ }^{31}$ As junk bonds did in their day, leveraged loans helped to finance many of the recent leveraged restructurings, including mergers and acquisitions and large dividend payments. Because they are not "securities" under the federal securities laws, leveraged loans trade in overthe-counter secondary markets beyond the purview of regulatory agencies. That is fine, since there is no evil in this arrangement calling for registration requirements or substantive regulation. However, I recommend some modest transparency requirements for this market, so that regulators can get up to speed.

Part V also suggests conceptual improvements to our regulatory and risk management models for the liquidity dynamics of the new credit market. ${ }^{32}$ Leverage

27. See infra Part III.

28. Ben S. Bernanke, Chairman, Fed. Reserve, Address at the Economic Club of New York: The Recent Financial Turmoil and its Economic and Policy Consequences (Oct. 15, 2007), available at http://www.federalreserve.gov/newsevents/speech/bernanke20071015a.htm ("The retreat by investors from structured investment products [based on housing finance] also affected business finance. . . . Demand for leveraged loans slowed sharply, reducing credit access for private equity firms and other borrowers seeking to finance leveraged buyouts (LBOs).").

29. See, e.g., Int'L Monetary Fund, Global Financial Stability Report: Financial Market TURBulence: Causes, CONSEQUENCES, AND POlicies 14 (2007) [hereinafter IMF, 2007 Financial STABILITY REPORT], available at http://www.imf.org/external/pubs/ft/GFSR/2007/02/pdf/text.pdf (comparing higher loan-to-value ratios, negatively amortizing loans, and cash-out refinancing features in subprime residential mortgages with high debt-to-eamings ratios, covenant-light debt, and dividend recapitalizations in the leveraged loan market).

30. While noting that '[o]ther terms for high-yield, such as 'speculative-grade' and 'junk bond,' have given the asset class some negative connotation over the years," the main argument that the rating agency makes against the moniker is that it is a big market: "[H]igh-yield has matured into a solid $20 \%$ of the overall corporate bond market." STANDARD \& POOR's, High YIELD BOND MARKET PRIMER 1 (2007) [hereinafter STANDARD \& POOR'S, PRIMER].

31. The Evolution of the U.S. Second-Lien Leveraged Loan Market-2006 Year-End Update, FircH RATINGS, Jan. 17, 2007, at 3.

32. My interest in liquidity began while I was an attorney at the SEC, where I participated in interagency surveillance of the repurchase agreement market and in-market structure inspections of the stock exchanges, the NASD, clearing agencies, and other industry utilities. I then went to the Office of the Comptroller of the 
regulators should make greater use of market structure analyses, of which Parts II-IV are examples. Also, the risk management models used by firms should assume more extreme liquidity events of the type that recently activated the loop between firm and market liquidity.

\section{A LIQUIDITY ACCOUNT OF CORPORATE LEVERAGE MARKETS}

Let me start by explaining the major liquidity dimensions of the corporate leverage market. First, I distinguish between firm and market liquidity. The two are different, although explaining the feedback loop between them is one of this Article's goals.

\section{A. Borrowing and Firm Liquidity}

A firm may finance its activities either by borrowing or by issuing shares to owners. In general, borrowing costs less than issuing equity because lenders may accept a lower return on their investment in the firm than will shareholders, whose financial interest in the firm is subordinated to that of creditors. ${ }^{33}$ Also, the after-tax cost of debt tends to be lower than that of equity because the firm can deduct interest payments but not dividends. Firms borrow to finance operations, pay off maturing debt, or transfer proceeds to owners. When borrowing to finance an extraordinary transaction, such as acquiring a company or rearranging the borrower's capital structure, these deals are considered "leveraged restructurings," insofar as they increase the firm's debt both in absolute terms and in proportion to the borrower's equity capital.

The firm may take out a loan from a professional lender or raise debt capital in the open capital market by issuing securities, such as bonds. Based on their probability of default, bonds of high credit quality are considered "investment-grade," while those of lesser quality are rated "subinvestment-grade" or, as known colloquially, "junk." 34 Based on a similar evaluation of a loan's credit quality, a loan may be investment-grade or, like the leveraged loans discussed later, subinvestment grade. ${ }^{35}$ The rate on the loan that a borrower takes out may be fixed, as in a conventional 30-year fixed-rate mortgage, or it may float with open market interest rates. The rates on most firm borrowing before the 1970 s tended to be fixed. ${ }^{36}$ U.S. banks had lent at floating rates abroad but not in

Currency's Treasury and Market Risk Division, which regulated the bank trading book and oversaw bank liquidity management. Between the two positions, I had the opportunity to compare securities and banking approaches to liquidity regulation, learning to understand liquidity in the context of capital markets. As it became clear that liquidity dynamics had contributed to the current credit crunch, I wrote this Article to share what I had learned in practice and to explore its theoretical implications.

33. When shareholders do not demand dividends, equity probably becomes effectively cheaper than debt.

34. Jerome S. Fons, Tracing the Origin of "Investment Grade," MOOdY's SPECIAL COMMENT (Moody's Investors Serv., New York, N.Y.), Jan. 2004, at 4 (analyzing the history of bond ratings).

35. See Steven Bavaria, Introduction: Rating Agencies in the Loan Market, in THE HANDBOOK OF LOAN SYNDICATIONS \& TRADING 521, 522-24 (Allison Taylor \& Alicia Sansone eds., 2007) [hereinafter LOAN SYNDICATIONS HANDBOOK] (analyzing the evolution of ratings for loans).

36. Interest rate historians Sidney Homer and Richard Sylla identify 1981 as the peak of this trend: "At their 1981 peaks, seasoned prime long corporate bonds were selling to yield $15.50 \%$. Commercial paper yields reached $16.66 \%$, three-month Treasury bills sold to yield about $16.30 \%$, and the Federal Reserve's discount rate was raised to $14 \%$. The annual average of the prime rate in 1981 was $18.87 \%$." SIDNEY HOMER \& RICHARD SYLLA, A HISTORY OF INTEREST RATES 335 (4th ed. 2005) [hereinafter HISTORY OF INTEREST]. 
domestic markets. ${ }^{37}$ This began to change in the 1970 s, as banks lent at floating rates domestically to protect themselves from rising interest rates. ${ }^{38} \mathrm{~A}$ floating rate exposes the borrower to the risk that interest rates will rise, adding to the borrower's interest costs. ${ }^{39}$ But this risk may suit the borrower if it does not expect rates to rise; just as the risk may suit a lender that thinks that rates will rise. Among floating rates, the London Interbank Offering Rate (LIBOR) has become the most commonly used rate for corporate borrowing. ${ }^{40}$

Borrowing impacts a firm's funding liquidity, which is its ability to manage its cash flow and credit such that it can service its debt obligations as they mature. Too much borrowing can lead lenders to raise the rate on the borrower's loan, demand more collateral for their credit exposure to the borrower, shorten the term of lending, or refuse to lend at all. ${ }^{41}$ Worse still, a rating agency may notch down a borrower with too much debt. ${ }^{42}$ And the perception that a firm has funding liquidity trouble may become a selffulfilling prophecy, as the president of Bear Stearns ruefully observed..$^{43}$ To understand

37. See Harold van B. Cleveland \& Thomas F. Huertas, Citibank 1812-1970, at 267-68 (1985) (analyzing the history of Citibank).

38. Homer and Sylla explained:

Variable- or floating[-]rate instruments-loans, notes and mortgages-came in as another way to cope with market fluctuations and inflation. The interest rate on instruments was linked to other key interest rates, such as U.S. Govemment bill, note, and bond rates, or the London Inter-Bank Offered Rate (LIBOR), a rate akin to the U.S. Federal Funds rate, in the Eurodollar market. To the extent that such key interest rates follow inflation rates, there is little difference between variableor floating-rate financing and inflation indexing.

HISTORY OF INTEREST, supra note 36 , at 433.

39. See Office of the Comptroller of the CuRrency, Comptroller's Handbook on INTEREST RATE RISK 14-18 (1997) (distinguishing between different types of interest-rate risk).

40. Companies have an estimated $\$ 9$ trillion in debt pegged to the LIBOR. Carrick Mollencamp et al., Libor's Rise May Sock Many Borrowers, WALL ST. J., Apr. 19, 2008, at B1 (analyzing the impact of climbing LIBOR rates on borrowers' funding liquidity). Calculated by the British Bankers' Association, the LIBOR is intended to reflect the average cost of borrowing to banks in the London money market. Id.

41. Funding liquidity risk may take other forms, but the common signs are rising funding costs, requests for collateral, a rating downgrade, decreases in credit lines, or reductions in the availability of long-term funding. OFFICE OF THE COMPTROLLER OF THE CURRENCY, COMPTROLLER'S HANDBOOK ON LIQUIDITY 1 (2001) [hereinafter LIQUIDITY HANDBOOK], available at http://www.occ.treas.gov/handbook/liquidity.pdf.

42. It is actually a company's unsecured senior long-term debt that gets rated up or down, not the company overall. CAROLYN E.C. PARIS, DRAFTING FOR CORPORATE FINANCE: WHAT LAW SCHOOL DOESN'T TEACH YOU 29 (2007) ("Rating agencies rate securities, not companies. If you want to use a rating to refer to a company's creditworthiness, you would refer to the rating of the company's unsecured unsubordinated longterm debt.").

43. Alan Schwartz, President \& C.E.O., Bear Stearns Cos., Statement Before the U.S. Senate Banking Committee 1 (Apr. 3, 2008), available at http://online.wsj.com/public/resources/documents/SchwartzTestimony 040308.pdf.

Due to the stressed condition of the credit market as a whole and the unprecedented speed at which rumors and speculation travel and echo through the modern financial media environment, the rumors and speculation [about Bear's illiquidity] became a self-fulfilling prophecy. . . . As the week progressed, unfounded rumors grew into fear and our liquidity cushion dropped precipitously on Thursday, as customers withdrew cash and repo counterparties increasingly refused to lend against even high-quality collateral. There was, simply put, a run on the bank.

Id. The Chairman of the SEC concurred: 
how borrowing affects a firm's future funding liquidity, careful firms play liquidity war games that consider how different scenarios will impact the firm's ability to weather adverse markets. ${ }^{44}$

A firm may borrow from a federally regulated bank or a nonbank lender, like an investment bank, hedge fund, or insurance company. Both bank and nonbank lenders are financial intermediaries because they borrow to lend, standing between the ultimate lender and the ultimate borrower and brokering their respective preferences about credit. ${ }^{45}$ Federal law caps the amount of leverage that a bank can assume. ${ }^{46}$ Nonbank lenders need not comply with federal limits on how much the lender can leverage itself. ${ }^{47}$ Nor do nonbank lenders disclose much to regulators, so they may have a leg up in the lending business. ${ }^{48}$ Firms that borrow to lend present generic risks to themselves, other firms, and the credit market as a whole, a point elaborated on later. ${ }^{49}$

\section{B. Secondary Market Liquidity and Its Links to Borrower Liquidity}

Rather than holding a loan to maturity, one of these lenders may sell it to another

For the first time, a major investment bank that was well-capitalized and apparently fully liquid experienced a crisis of confidence that denied it not only unsecured financing, but short-term secured financing, even when the collateral consisted of agency securities with a market value in excess of the funds to be borrowed. Counterparties would not provide securities lending services and clearing services.

Christopher Cox, Chairman, Sec. \& Exch. Comm'n, Testimony Before the Senate Committee on Banking, Housing, and Urban Affairs Concerning Recent Events in the Credit Market (Apr. 3, 2008) [hereinafter Cox Testimony].

44. The advice given to banks by their regulators applies with equal force to other firms too: use a contingency funding plan to anticipate both routine and extraordinary needs for liquidity. LiQuiDITY HANDBOOK, supra note 41 , at 37 . Whether a borrower anticipates and provides for different liquidity scenarios manages or waits for funding emergencies to arise, the borrower is, in effect, following a contingency funding plan.

45. For example, during the 30 -year period ending in 1998, the share of commercial credit provided by banks dropped from $43 \%$ to $26 \%$ while that of nonbank intermediaries increased from $30 \%$ to $48 \%$. BD. OF GOVERNORS OF THE FED. RESERVE SYS., GUIDE TO THE FLOW OF FUNDS ACCOUNTS 28 (2000) [hereinafter FLOW OF FUNDS]. The amount of credit provided by the nonfinancial sector stayed roughly the same, ranging from $22 \%$ to $27 \%$ during this period. $I d$.

46. 12 C.F.R. pt. 3 (2008).

47. For example, banks must comply with federal capital adequacy rules that impose additional capital costs, which are probably passed off to borrowers: "Ignoring transaction costs, a bank with market-rate funding would have to charge the borrower some $75-100$ basis points attributable to capital requirements, in order to provide an adequate return on equity to its shareholders." Stephen A. Lumpkin, The Integration of the Corporate Bond and Commercial Loan Markets, FIN. MKT. TRENDS, Nov. 2003, at 51, 53. Banks also benefit from nonmarket funding sources like the discount window and deposit funding at a below market interest rate due to the federal deposit insurance guarantee, so any net effect of this regulatory capital cost must be viewed in the context of a bank's all-in cost of capital.

48. Private-Equity Firms Still in the Money, WaLl ST. J., July 3, 2007, at $\mathrm{Cl}$ (noting the nimbleness of private equity funds to develop new strategies when regulators begin investigating their market practices and commenting: "Similarly, don't underestimate private equity's knack for making money in just about any environment. Call it feral adaptability.").

49. For example, a bank-or other lender-faces liquidity risk when it is called on to fund a loan. For that reason, a revolving or contingent credit commitment that may have to be funded in the future creates more uncertainty and, hence, liquidity risk to the lender. 
investor in what is known as the "secondary market." Another kind of liquidity comes into play here: market liquidity. ${ }^{50}$ This kind of liquidity speaks to the ease with which one can trade an asset (in this case, a loan) at its expected price. ${ }^{51}$ You can gauge market liquidity by measuring the difference between the sale price and the purchase price of a fungible commodity: the narrower this spread, the more liquid the market is said to be. ${ }^{52}$ For example, a "fire sale" price reflects a market liquidity discount. The depth of supply and demand also influences an asset market's liquidity. ${ }^{53}$ Reliable market liquidity requires professional dealers (like the specialists on the New York Stock Exchange) who stand ready to trade from their own account to manage trading volume. ${ }^{54}$

Firm funding liquidity and asset market liquidity are different, although both measure imminent value in a real-time market for, respectively, a firm and an asset. Part of this Article's goal, though, is to demonstrate how firm and market liquidity interact. Selling loans liquifies a lender's assets by letting it convert a loan into cash, with which it can make new loans. ${ }^{55}$ This is the first axiom about the relationship of firm and market liquidity: a firm can enhance its own funding liquidity by drawing on the market liquidity of its assets. Conversely, when market liquidity evaporates, so too can the funding liquidity of firms. As global banking regulators noted about the current credit turbulence,

50. Scholars also distinguish between two kinds of market liquidity risk: exogenous risks affecting the market as a whole and endogamous ones that affect a particular firm. Anil Bangia et al., Modeling Liquidity Risk, with Implications for Traditional Market Risk Measurement and Management 4 (Wharton Fin. Inst. Ctr., Working Paper No. 99-06, 1999).

51. For example, a trader wanting to sell a large block of securities may pay a liquidity discount for selling the block at once because its size may clear all demand at the best bid price such that part of the sale must be executed at less attractive bids. (The price cycle is repeated into a falling market until the seller liquidates the entire block.) Contra, a trader wanting to buy a large block may pay a liquidity premium because the desired size of the block may clear all supply at the best offer price such that part of the purchase must be executed at higher offer prices. A deep and liquid secondary market is one in which there is enough buy-interest behind the bids and sell-interest behind the offers such that large transactions can be executed without paying liquidity discounts or premiums.

52. Market liquidity includes several aspects of how a transaction is consummated in a market:

The dimensions of market liquidity include: market "depth," or the ability to execute large transactions without influencing prices unduly; "tightness," or the gap between bid and offer prices; "immediacy[,]" or the speed with which transactions can be executed; and "resilience," or the speed with which underlying prices are restored after a disturbance.

Andrew Crockett, Market Liquidity and Financial Stability, FIN. STABILITY REV., Feb. 2008, at 13, 14.

53. For example, the volume of secondary market trading in corporate loans climbed from $\$ 8$ billion a year in 1991 to over $\$ 100$ billion a year in 2000 and then climbed slowly to over $\$ 238$ billion in 2006 . Reuters Loan Pricing Corp., U.S. Secondary Loan Market Volume, http:/www.loanpricing.com/analytics/pricing service_volumel.htm (last visited Oct. 18, 2008). These figures express the then market value of the loans, i.e., par for loans that were not distressed and the discounted rate for distressed loans.

54. As Minsky points out, proprietary dealers are in the best position to add stabilizing liquidity in the secondary market by taking positions against the market trend: "[T] $T$ here needs to be a set of position-takers who will buy significant amounts for their own account and who sell out of their own stock of assets." MINSKY, CAN IT?, supra note 24 , at 149 (noting the fundamental instability of a capitalist economy in the tendency to explode).

55. This is the same dynamic at work in the Federal Reserve's attempts to inject liquidity by acting as a "buyer." In the case of the central bank's open market operations, it lets banks and primary dealers "liquify" themselves by trading securities for cash. 
financial instability "flowed" through asset markets and into banks. ${ }^{56}$ As the IMF put it, "market illiquidity can quickly become funding illiquidity" (and vice-versa, as I later point out). ${ }^{57}$

One sees the first axiom at work in a rarified lending market that the Bear deal brought into the limelight: the repurchase agreement (repo) market. ${ }^{58}$ In this market, a firm holding a security can make money on it (without parting with it for good) by pledging it as collateral for a loan. Due to market convention, the loans are styled as back-to-back purchase and sale agreements, typically for a term of one day that gets rolled over into a longer effective term. ${ }^{59}$ The deal liquifies the security by letting the cash borrower convert the security to cash for the term of the loan, thereby enhancing the borrower's own funding liquidity. ${ }^{60}$ Especially for investment banks with large securities portfolios, the repo market is one of their most important ways of funding their activities day to day because repo (and reverse repo deals that are the mirror image of the transaction) let the firm reduce the carrying costs of their securities portfolios. ${ }^{61}$

Depending on how badly the cash lender wants the security (typically to avoid failing on its duty to deliver that security in a short sale), it will charge the cash borrower an interest rate on the cash loan below the market rate or even a "negative interest rate," i.e., effectively paying the cash borrower for the privilege of holding the collateral during

56. WORKING GROUP ON LIQUIDITY, BASEL COMM. ON BANKING SUPERVISION, LIQUIDITY RISK: MANAGEMENT AND SUPERVISORY CHALLENGES 11 (2008) [hereinafter BASEL COMM.] ("The loss of investor confidence in a wide range of structured securities markets led to risks flowing on to banks' balance sheets.”).

57. Jaime Caruana \& Laura Kodres, Liquidity in Global Markets, FIN. STABILITY REv., Feb. 2008, at 65, 66.

58. Although not well known, repo markets serve key background functions in the financial system. First of all, the Fed conducts monetary policy by adjusting liquidity in the banking system through repo deals, as it has in the liquidity injections mentioned earlier. The Fed, the SEC, and the U.S. Treasury surveil this market because it can be the first place where problems emerge that can have wider implications for the financial system. DeP'T. OF THE TREASURY, SEC. AND EXCH. COMM'N \& BD. OF GOVERNORS OF THE FED. ReSERVE SYS., JOINT REPORT ON THE GOVERNMENT SECURITIES MARKET 1-5 (1992), available at http://www.treasury.gov/offices/domestic-finance/debt-management/gsr92rpt.pdf.

59. The market includes both repurchase and reverse repurchase agreements. See Stephen A. Lumpkin, Repurchase and Reverse Repurchase Agreements, in INSTRUMENTS OF THE MONEY MARKET, supra note 2, at 59,59 . Both types of agreements involve two sequential steps: a purchase by A of a security belonging to B followed by the sale by $A$ of the same (or a substitute) security to $B$. In a repurchase agreement, a firm pays cash for a security from a counterparty, who promises to unwind the deal at the end of the agreement by "buying back" the security. Entering into a repo reduces the firm's liquidity (because cash has been exchanged for a security) but, booked as an asset on the firm's balance sheet, the repurchase agreement is viewed as a highly liquid asset because cash for it is forthcoming. The opposite happens in a reverse repurchase agreement, which is booked as a liability for a firm. This time the reverse repo obligates the firm to pay cash for a forthcoming buyback of a security from a counterparty who tendered the cash in exchange for the security on the first leg of the deal. Financial intermediaries like these agreements because they are a flexible way to eam a profit on excess cash or capture the collateral value of a security that is on "special," i.e., in demand, perhaps because of uncovered short sales of the security, $I d$. at 68 .

60. Each of the two counterparties to a repurchase agreement wears two hats: the cash borrower is also the securities lender, and the cash lender is also the securities borrower.

61. Repurchase Markets, WALL ST. J., Mar. 17, 2008, at Cl (finding that up to one-fifth of the securities inventory of major firms tends to be "repoed" out); see also Michael J. Fleming \& Kenneth D. Garbade, Repurchase Agreements with Negative Interest Rates, CURRENT ISSUES ECON. \& FIN., Apr. 2004, at 1, 2 (finding that in 2003 investment banks were financing $\$ 2.41$ trillion of fixed-income securities in their portfolios through repo). 
the term of the loan. ${ }^{62}$ What is distinctive about negative interest rates in the repo markets (known as "specials") is that, from the point of view of the cash lender, they illustrate a negative liquidity preference. That is, the cash lender would rather sacrifice liquidity (cash) for the chance to hold the collateral, so it is really the cash that collateralizes the loan of the security. 63

To understand the second major liquidity axiom, you must understand the role played by secondary credit markets. These secondary markets involve a key dispute about the role of secondary credit markets in the current credit turbulence: did these secondary markets make the credit market more or less stable? (It would seem that secondary market liquidity did both.) One advocate for secondary credit markets claims that these markets mitigate the effect of a recession by making more liquidity available to borrowers. ${ }^{64}$ In other words, market liquidity would "carry over" into the firm's funding liquidity, as it does in the repurchase market. Yet hyper-liquidity in the secondary market (and the anticipation that it would continue) for corporate credit products also led firms to borrow more as lenders relaxed underwriting standards in the knowledge that a ready secondary market would purchase even dubious loans. ${ }^{65}$ This works so long as the secondary market digests loans, but if it sputters then unwanted loans become stranded on the lender's balance sheet. When that happens, the loan's value to the lender reverts back to the cash flow expected from the loan, not the proceeds of selling the loan.

These secondary markets illustrate the second axiom about the relationship between a firm's liquidity and that of the market: frothy liquidity in the secondary market for a firm's liability may not be a proxy for the credit quality of the liability or, indeed, a borrower's own liquidity. As one commentator put it, the value of a "debt should not correlate with market liquidity" but with its underlying cash flow. ${ }^{66}$ As a matter of microeconomics, a purchaser in the secondary market should pay no more than the value of the loan's discounted cash flow. When loans are changing hands in a trading market, however, investors may take their cues about the loan's value from each other's assessments about value, rather than from an independent evaluation of the loan's underlying cash flows. ${ }^{67}$ That is, investors join the herd in a "beauty contest" where the contestants are loans and the judges are other investors; in this context, an investor may

62. See Fleming \& Garbade, supra note 61 , at 1 (generalizing about negative interest rates from the 2003 repo market for a ten-year Treasury note).

63. This type of loan is the opposite of the leveraged liquidity analyzed by this Article, a point I take up later. See infra notes $155-56$ and accompanying text.

64. It is a bullish view of credit markets: the bank loan market lets lenders "remove riskier loans from their balance sheets. This enables lenders to avoid restricting credit when the economy contracts. By providing a steady stream of credit into the business sector, the impact of a recession may be reduced." GLENN YAGO \& DONALD MCCARTHY, MILKEN INSTIT., THE U.S. LEVERAGED LOAN MARKET: A PRIMER 37 (2004), available at http://milkeninstitute.org/pdf/loan_primer_1004.pdf.

65. So argues Michael Cavan in an article on "debtquity," an asset class which is formally debt but without the benefit of the underwriting standards and covenant protections which are typical of debt. Michael A. Cavan, "DebtQuity": A Perspective on the Current Blur Between Debt and Equity, AM. BANKR. INST. J., JulyAug. 2006, at 14, 14 ("The overabundance of funds in the market has put pressure on lenders that would have followed more traditional financing terms and related due diligence to place debt in situations where they would have had tougher covenants and higher pricing on debt.").

66. Id. at 66 .

67. This is what traders have in mind when they say that a financial asset has gone from being a "cash flow" product to one based on "market value," i.e., its trading value in the secondary market. 
buy a loan without doing a credit analysis if other investors also seem interested in the loan. ${ }^{68}$ Support for the proposition that the beauty contest distorts pricing comes from the argument that mark-to-market pricing (to secondary market expectations) when liquidity is tight may not reflect a loan's fundamental value ${ }^{69}$ If so, goes this argument, mark-tomarket pricing would contribute to price "contagion," reducing the value of the loan asset on an investor's balance sheet and, at the same time, compromising the investor's funding liquidity by leaving it with assets of less value with which to satisfy its maturing obligations. ${ }^{70}$ But this is only half of the picture: market pricing may not reflect fundamental value on the upside of the market either, during which the beauty contest leads to "upside contagion" by inflating the book value of traded assets.

Indeed, a stronger version of the second axiom is that a borrower's funding liquidity can decline as market liquidity for its liabilities increases. This is what happened with the leveraged loan market discussed later in the case study. ${ }^{71}$ For example, bondholders that had already lent to firms complained when these firms also took out leveraged loans, for which a secondary market was growing and, indeed, booming. ${ }^{72}$ From the bondholders' perspective, these complaints were justified by the fear that, as one study found, these bondholders might recover less on their bonds than if the firm had not taken out these loans. ${ }^{73}$

\section{The Summer 2007 Market Break in Liquidity}

Focusing on borrower and market liquidity helps to understand what happened in the summer of 2007. The story starts in the boom period of a corporate leverage wave. There have been at least three such waves since the 1970s during which firms borrowed heavily for leveraged restructurings. ${ }^{74}$ Traditionally, merger waves target companies with stable

68. Economist John Maynard Keynes coined the phrase: "Keynes likened the stock market to a 'beauty contest' where participants devoted their efforts not to judging the underlying concept of beauty, but instead to 'anticipating what average opinion expects the average opinion to be."' Kevin J. Lansing, Asset Price Bubbles, FRBSF ECON. LETTER (Fed. Reserve Bank of S.F., S.F., Cal.), Oct. 26, 2007, at 1, 3 (citation omitted), available at http://www.frbsf.org/publications/economics/letter/2007/el2007-32.html. In such a contest, "speculators base their expectations of future asset prices not only on what they think the true values is, but, more importantly, on what they think the average opinion about the average opinion is." Korkut A. Erturk, On the Minskyan Business Cycle 10 (Levy Econ. Inst., Working Paper No. 474, 2006), available at http://papers.ssm.com/sol3/papers.cfm?abstract_id=928451.

69. See generally Franklin Allen \& Elena Carletti, Mark-to-Market Accounting and Liquidity Pricing (July 20, 2006) (unpublished manuscript, on file with author) (arguing that mark-to-market accounting does not reflect the "true value" of bank assets during periods of tight market liquidity).

70. Id.

71. Serena Ng, Investors Fret Buyout-Induced Risk-Some Money Managers Fear Surge in Leveraged Deals Stretches Corporate Finances, WALL ST. J., July 18, 2006, at C4 (noting that in the past year one credit rating agency-Fitch-had lowered its credit ratings or credit outlooks on $\$ 53$ billion in corporate debt obligations).

72. Fitch Ratings, The Evolution of the U.S. SeCOND-Lien Leveraged LOAN MaRket-2006 YEAR-END UPDATE 2 (Jan. 17, 2007) (finding that a "substantial majority" of leverage deals involved leveraged loans).

73. Fitch Ratings, Speculative Grade Balance Sheets Becoming more loan-HeavyRECOVERY PROSPECTS AT RISK (2007).

74. See, e.g., Li Jin \& Fiona Wang, Leveraged Buyouts: Inception, Evolution, and Future Trends, PERSPECTIVES, Sept. 30, 2002, http://www.oycf.org/Perspectives2/18_093002/Leveraged_Buyouts.htm (tracing 
cash flows, often in manufacturing. This time, though, acquirers went after companies in sectors with cyclical cash flows or companies with large intangible assets, whose cash flow may be even less stable. ${ }^{75}$ Also, this time there was more rapid cycling of cash to owners and more financing from foreign investors. ${ }^{76}$ The size of the mergers increased too. ${ }^{77}$ During the last merger wave, lenders waived many of the promises that they typically extract from borrowers. ${ }^{78}$ A study by Standard \& Poor's of rated secured borrowings found that almost one-third of the dollar value of the 500 secured debt issues in the study consisted of "covenant-lite" loans, lacking debt covenants typically found in such issues. ${ }^{79}$ And after the loans were made, some corporate borrowers could cut their interest rate on existing loans just by asking. ${ }^{80}$

Borrowers with the upper hand (or so it had seemed at the time) took on loans to execute a record number of mergers, acquisitions, and restructurings of their own capital. Many of these were so called "shareholder-friendly" transactions because they transferred

leverage buyout cycles from 1980 to 2000). Flow of funds data from the Federal Reserve supports their assertion. BD. OF GOVERNORS OF THE FED. RESERVE SYS., GUIDE TO THE FLOW OF FUNDS ACCOUNTS 23-26 (2000) (finding debt growth in the household, government, and commercial sectors). The first phase of equity extraction occurred during the junk bond boom between 1984 and 1990, during which nonfinancial corporations withdrew nearly $\$ 650$ billion in equity. Id. at 26. Flow of funds data for the period between 1993 and 1997 suggests a similar pattern of high debt issuance and equity extraction occurred, as reflected in flow of funds data. Id. (This data set ends in 1997.) This second period roughly corresponds with a small wave of leveraged buyouts beginning around 1996. Id. (noting that the dollar value of leveraged buyouts approached the volumes of the early 1980s). A similar leverage trend seems to have been underway recently too, as suggested by the increase in corporate leverage since 2000: in 2000, the ratio of gross debt underwriting to gross equity issuance was 5 ( $\$ 1.28$ trillion of corporate debt underwriting supported by $\$ 204$ billion of equity issuance), but by 2007 the ratio had doubled to 10:1 (i.e., $\$ 3$ trillion of debt issuance supported by $\$ 247$ billion). SEC. INDUS. \& FN . MKTS. ASS'N, U.S. CORPORATE UNDERWRITING ACTIVITY 1, http://www.sifma.org/research/statistics/other/ Equity.pdf (last visited Feb. 4, 2009). Ideally, one would compare net issuance (or repayment) of debt and net issuance (or extraction) of equity, but I have not been able to find comprehensive data on net capital structure figures for more recent periods.

75. Mark Whitehouse, Deals and Dealmakers: LBOs May Spoil the Corporate-Bond Party-PrivateEquity Firms Ladle Debt Onto Investment-Grade Buyouts Putting Ratings, Prices at Risk, WaLL St. J., Aug. 1, 2005, at C1 ("As low-hanging fruit becomes scarce, buyout artists are going after companies with shakier finances.").

76. See id. (discussing cash cycling). In mergers and acquisitions involving financial institutions, the percentage of deals involving entities outside of a single country increased from less than $1 \%$ in 1996 to nearly $40 \%$ in 2006. INT'L MONETARY Fund, 2006 Global FinANCIAL STABILITY RePORT 99 (2006) [hereinafter IMF, 2006 FINANCIAL STABILITY REPORT].

77. Press Release, Mergerstat, M \& A Wrap Up for 2006 (Jan. 1, 2007), available at http://www.mergerstat.com/newsite/press/release35.htm (reporting over 11,000 deal announcements for 2006).

78. Jacqueline Doherty, For Banks, a \$300 Billion Hangover, BARRON's, Aug. 27, 2007, at 21 (analyzing commercial and investment bank financing of 12 large leveraged buyouts to show how weak covenants exposed the lenders to interest-rate risk).

79. STANDARD \& POOR'S, THE LEVERAGING OF AMERICA: COVENANT-LITE LOAN STRUCTURES DiMINISH RECOVERY PROSPECTS 5 (2007).

80. Cynthia Koons, Just Saying No to Repricings-Investors Rein in Market That Funds Leveraged Buyouts, WALL ST. J., Apr. 27, 2007, at C5 (referencing Reuters loan pricing data that between January, February, and March lenders had cut rates on between $\$ 16.6$ to $\$ 44.3$ billion each month but that for April only $\$ 1$ billion in loans had been repriced); see, e.g., Serena $\mathrm{Ng}$, Bond Investors' Lament-Fallout as Moody's, S\&P Cut Ratings on Issues Tied to Subprime Loans, WALL ST. J., May 3, 2007, at C1 (reporting on actual or potential credit downgrades of $\$ 1$ billion in securitizations of high-yield mortgage loans, including investmentgrade securities). 
value (often borrowed value) to firm owners through share purchases or dividends on shares. ${ }^{81}$ One thinks of dividends as a return to owners of their firm's net profits, but this time many firms borrowed to pay "leveraged" dividends to their owners. ${ }^{82}$ Because borrowing to fund a dividend leaves the firm more highly leveraged and, if it is a floating-rate borrowing, exposed to interest-rate risk, financiers mordantly called them "drive-by" dividends. ${ }^{83}$ In general, this time the cash moved more quickly from lenders through borrowers and, then, up to the borrower's owners, leaving the borrower with unproductive debt. This cash cycle had taken an average of seven years for private buyout groups in the 1980s; but this time the horizon of private equity investors shortened, sometimes to only months. ${ }^{84}$

Credit downgrades of firms piled up before the July 2007 credit crunch. ${ }^{85}$ In the first quarter of 2007, downgrades of nonfinancial companies exceeded upgrades. ${ }^{86}$ Banking and finance firms did better than nonfinancial sectors, given that the lion's share $(80 \%)$ of all credit rating upgrades were of banking and finance firms. ${ }^{87}$ Eventually, though, even financial firms became riskier, despite the surplus profits from fees charged to other firms for their leveraged deals. ${ }^{88}$ The number of issuers rated subinvestment-grade also

81. Greg Ip \& Jon E. Hilsenrath, How Credit Got So Easy and Why It's Tightening, WaLL ST. J., Aug. 7, 2007 , at $\mathrm{A} 1$ ("By 2006, the volume of such leveraged buyouts was smashing records from the 1980 s. Generous credit markets enabled private equity firms to do larger deals and pay themselves bigger dividends.").

82. Robert McNatt \& Frank Benassi, The Dividend Recap Game: Credit Risk vs. the Allure of Quick Money, STANDARD \& POOR's, Aug. 7, 2006, http://www2.standardandpoors.com/portal/site/sp/en/us/ page.article/2,1,1,0,1145848227253.html (giving the example of a $\$ 1$ billion leveraged dividend which returned half of the capital investment of a private equity group). By one estimate, the annual volume of leveraged dividends increased from under five billion in 2000 to between 20 and 40 billion in 2004-2006. Id. Borrowing to capitalize a dividend works to the detriment of bondholders in two ways: it increases the firm's leverage and, at the same time, reduces its asset liquidity by upstreaming value to shareholders. See Victor Okoth \& Chris Volta, The Pros and Cons of Dividend Recapitalization, CAPITAL EyEs (Bank of America, Charlotte, N.C.), Sept._Oct. 2006, available at http://corp.bankofamerica.com/public/public.portal?_pd_page_label=products/ abf/capeyes/archive_index\&dcCapEyes=indCD\&eFile $=\mathrm{C} 0333 . \mathrm{html}$ ("The desire to return capital to the limited partners has been one of the primary drivers of the dividend recap trend over the last few years.").

83. It is a telling phrase: "The temptation to load up on debt is exacerbated by the fact that dividend recaps can be planned and carried out quickly-sometimes within a matter of days. 'They're sometimes called "drivebys" because they can be that opportunistic,' said Standard \& Poor's credit analyst Sucheet Gupte." McNatt \& Benassi, supra note 82.

84. See generally Steven N. Kaplan, The Staying Power of Leveraged Buyouts, 29 J. FN. ECON. 287 (1991) (using seven year estimate); Sarah Childress \& Dennis K. Berman, BCE's \$32.6 Billion Buyout Reinforces a Private Equity Trend, WALL ST. J., July 2, 2007, at A2 ("This deal [the buyout of a Canadian telecommunications company] is another in a crescendo of buyouts in which private-equity firms take on increasingly greater targets, looking for ways to spend ever-larger troughs of cash, collecting fat management and transaction fees along the way."). Nevertheless, even re-released public companies may remain profitable. See Jerry Cao \& Josh Lemer, The Performance of Reverse Leveraged Buyouts 4 (Nat'1 Bureau of Econ. Research, Working Paper No. 12626, 2006) (analyzing several hundred leveraged buyouts between 1980 and 2002 and finding that restructured firms were not compromised by the additional leverage).

85. For example, the 2005 downgrades of investment-grade debt of Ford Motor Company and General Motors added $\$ 80$ billion in "fallen angel" leveraged debt, making up nearly $10 \%$ of the high-yield bond market for that year. See STANDARD \& POOR'S, PRIMER, supra note 30, at 1.

86. U.S. Corporate Bond Market: A Review of First-Quarter 2007 Rating and Issuance Activity, FITCH RATINGS, May 15, 2007, at 6 (analyzing rating and issuance activity by industrial sector).

87. Id.

88. Libby Bruch, Standard \& Poor's, Trading Places-U.S. High-Yield Issuers Poised to Outnumber Investment-Grade Counterparts, INVESTINGINBONDS.COM, http://www.investinginbonds.com/news.asp?id= 
increased during this period. ${ }^{89}$ The occasional Cassandra had warned about impending risks, but speculative momentum increased through the summer of $2007 .{ }^{90}$ For most, the day of reckoning began in July 2007 as losses in subprime mortgages startled lenders and other investors. ${ }^{91}$

One of the first manifestations of financial distress was a dramatic spike in the floating-rate LIBOR. Usually it is no more than ten basis points $(0.1 \%)$ higher than the fed funds rate, the rate on uncollateralized interbank lending in the United States. ${ }^{92}$ By early August, though, the spread between the LIBOR and the fed funds rate had quadrupled to 40 basis points and it has remained wide and volatile since. ${ }^{93}$ Distress spread throughout the primary market. ${ }^{94}$ Corporate bond issuance declined, most notably in the high-yield sector. ${ }^{95}$ Equity underwriting shrank too. ${ }^{96}$ Short-term commercial paper was volatile, which is unusual because issuer default here is rare and may portend weakness elsewhere in financial markets. ${ }^{97}$ And demand for leveraged loans dropped. ${ }^{98}$ In the secondary market, trading liquidity shrank too as high-yield corporate bonds traded at widening discounts between July and August. ${ }^{99}$ Overall, the Securities Industry and Financial Markets Association (SIFMA) noted that the contraction had been "more

$1840 \&$ catid $=36$ (last visited Oct. 18,2008 ).

89. Id. (noting decline of issuers rated investment-grade from $72 \%$ in 1992 to $51 \%$ in 2006).

90. Many of these warnings rested on Minsky's financial instability thesis. See, e.g., Edward Chancellor, Ponzi Nation, INSTITUTIONAL INVESTOR, Feb. 2, 2007, at 9 (analyzing the U.S. housing boom in terms of drift toward speculative and Ponzi finance).

91. SEC. INDUS. \& FIN. MKTS. ASS'N, CAPITAL MARKETS REview SEPTEMBER 2007 (2007) [hereinafter SIFMA, CAPITAL MARKETS REVIEW], available at http://www.sifma.org/legislative/financial services/pdf/market-summary-907.pdf. Signs of financial weakness preceded the July market break, but concern did not become acute until Bear's problems with its hedge funds. See Markus K. Brunnermeier, Deciphering the 2007-08 Liquidity and Credit Crunch, J. ECON. PERSP. (forthcoming 2009) (pinpointing the beginning of the liquidity crisis to higher defaults of subprime mortgages in February 2007).

92. Stephen G. Cecchetti, Crisis and Responses: The Federal Reserve and the Financial Crisis of 20072008, at 7 (Nat'l Bureau of Econ. Research Working Paper Series, Working Paper No. 14134, 2008) (listing cuts to the target federal funds rate and the primary lending rate).

93. Id.

94. The declines showed up in each of the major credit classes: long-term debt issuance by federal agencies dropped to $\$ 57.2$ billion compared with a monthly average of $\$ 83.5$ billion for the first-half of 2007 ; issuance of "higher quality" mortgages dropped to $\$ 169.3$ billion compared with a monthly average of $\$ 193.2$ billion for the first half of 2007 ; and the issuance of asset-backed securities shrank to $\$ 39.0$ billion compared to a monthly average of $\$ 105$ billion. See SIFMA, CAPITAL MARKETS REVIEW, supra note 91, at 2-4.

95. Overall, corporate bond issuance shrank to $\$ 38.3$ billion in July compared to a monthly average of $\$ 108.6$ billion for the first half of 2007 ; in the high-yield sector, however, the contraction was more severe as issuance dropped to $\$ 2.4$ billion from an average of $\$ 15.9$ billion for the first half of 2007 . Id.

96. Equity underwriting halved from a monthly average of $\$ 22.2$ billion for the first half of 2007 to $\$ 12.6$ billion. Id.

97. Commercial paper issued by nonfinancial companies did not display unusual volatility but the risk premium for commercial paper that was backed by mortgages (and, effectively, guaranteed by banks) did increase dramatically. Cecchetti, supra note 92 , at 8-10.

98. See IMF, 2007 FINANCIAL STABILITY REPORT, supra note 29 , at 14 (“An estimated $\$ 300$ billion of leveraged loans was planned to come to the market in the second half of this year, equivalent to around onethird of the total shareholder equity of the top 10 banks most involved in financing leveraged buyouts. But overall demand for the loans ... is now uncertain.").

99. See SIFMA, CAPITAL MARKETS REVIEW, supra note 91 , at 4 . The daily trading volume of high-yield bonds increased in July to $\$ 4.23$ billion from a daily average of $\$ 3.97$ billion in the second quarter of 2007 as holders of these bonds dropped them in order to purchase less risky investments. Id. 
severe than many investors anticipated" and that "investor risk tolerance quickly has turned to risk aversion." 100

Less debt meant fewer "shareholder-friendly" deals. "Corporate Bond Market Has Come to a Standstill," said a Wall Street Journal article, as deals were reduced, postponed, or canceled outright. ${ }^{101}$ Deals that came to market paid more for the debt financing than expected. ${ }^{102}$ New deals were still being done, granted, but this time for discounted debt that had dropped in value as confidence receded. ${ }^{103}$ Lenders who had made funding commitments for leveraged restructurings in the pipeline suddenly faced the prospect of losses. ${ }^{104}$ Paraphrasing Minsky's financial instability thesis, a Banque de France official noted:

[A]n increase in leverage in the system makes it more vulnerable to a sudden re-appraisal of risks and abrupt shifts in the liquidity demand .... This fragility is concealed in periods of euphoria .... But it comes to the forefront again when distress erupts. As distress cascades through the system, liquidity providers turn into liquidity demanders. ${ }^{105}$

Leading up to the credit crunch of 2007 , some investment banks that had provided prime brokerage to hedge funds decided to limit their credit exposure to these hedge fund clients. ${ }^{106}$ While it made individual sense for each firm to cut off the hedge funds, the sum of these individual decisions had cascading effects as market liquidity dried up for structured credit products being sold by these same investment banks. ${ }^{107}$ This was an unintended effect of risk management caused by failing to appreciate the link between firm (in this case the hedge funds that had been stripped of credit) and market liquidity (in this case for the investment products sold by banks). ${ }^{108}$ This incident revealed a third

100. Id. at 1 .

101. Anusha Shrivastava, Corporate Bond Market Has Come to a Standstill, WALL ST. J., Aug. 7, 2007, at C2; see Michael Aneiro, Risky Debt Issuance Meets Investor Resistance, WALL ST. J., June 23, 2007, at B5 (discussing decisions by three issuers to shrink offering of high yield debt); Danielle Reed, A Mortgage-Bond Power Shift-Investors Spurn Commercial Loans Deemed to be Too Risky, WALL ST. J., May 4, 2007, at C7 (noting how prospective investors forced the issuer to exclude the underlying loan from securitization because of the loan's credit quality).

102. See Aneiro, supra note 101 (discussing reductions and cancellations of proposed deals).

103. See, e.g., Pierre Paulden, Lehman Raises \$3 Billion Fund to Purchase Buyout Debt, BLOOMBERG.COM, Oct. 29, 2007, http:/www.bloomberg.com/apps/news?pid=20601087\&sid=aIT37LNeTP vw\&refer=home (describing how Lehman Brothers has set up a $\$ 3$ billion Loan Opportunity Fund to buy market-discounted leveraged loans).

104. See Doherty, supra note 78, at 21 (analyzing commercial and investment bank financing of 12 large leveraged buyouts to show how weak covenants exposed the lenders to interest-rate risk).

105. Arnaud Bervas, Financial Innovation and the Liquidity Frontier, FIN. STABILITY REV., Feb. 2008, at 123, 128 (internal citation omitted).

106. Peter R. Fisher, What Happened to Risk Dispersion?, FIN. STABILITY REV., Feb. 2008, at 29, 32 ("In response to the decay in prices and the simultaneous rise in volatility, a number of major financial firms began to reduce their credit exposures to hedge funds, provided through their prime brokerage arms." (internal citation omitted)).

107. Id. By cutting off funding liquidity to the hedge funds, reducing credit exposure also made market liquidity dry up: "While [reducing credit exposure to hedge funds] may have been a prudent counterparty credit decision, it had the seemingly-unanticipated consequence of reducing demand for the very mortgage-backed securities and structured credit instruments that were being underwritten ...." Id. at 32.

108. Id. 
axiom about the link between firm and market liquidity: insofar as demand for financial products was underwritten by borrowing (in this case, borrowing by hedge funds from investment banks), the efforts of lenders to cut credit harmed the market for other products sold by these lenders. So, both borrower liquidity and market liquidity may themselves be leveraged insofar as either rests on layered borrowing, a theme that I explore more fully in the next Part.

For Bear, problems came to a head in the repo market. It was lender sentiment there that the firm's managers considered when evaluating the severity of the firm's liquidity crisis. ${ }^{109}$ And it was the refusal of Bear's repo lenders to extend overnight loans that confirmed that Bear had a liquidity crisis. ${ }^{110}$ Anxious about market conditions, these lenders preferred to hoard liquidity rather than to enter into collateralized loans. This preference was unusual since-at the time-Treasury securities were in great demand (including as collateral for loans) because investors take comfort in the creditworthiness of the U.S. government as an issuer. ${ }^{111}$ It was this crisis with Bear's repo lenders that induced the Fed to lend to Bear through the discount window: even though the firm was amply solvent, other firms had become reluctant to do repo with the firm, which was alarming because the repo market had been more immune to liquidity panics than even investment-grade commercial paper. ${ }^{112}$ As many wondered "whither liquidity?," the new credit market came into view, the bargaining power returned to lenders, and the Fed went into action.

\section{Saved by the Fed: Liquidity for All}

Between September 18, 2007 and April 30, 2008, the Federal Open Market Committee cut interest rates seven times, lowering the targeted (uncollateralized) federal funds rate and the (collateralized) discount window rate (also known as the "primary lending rate"). ${ }^{113}$ In addition to these conventional instruments of monetary and credit policy, the Fed also experimented with less typical tools, including extending the term of discount window and repo lending, establishing swap lines with European banks, andimportantly for purposes of this Article-creating new credit facilities for both commercial and investment banks. ${ }^{114}$ What is significant about these alternatives is that

109. Bryan Burroughs, Bringing Down Bear Stearns, VANITY FAIR, Aug. 1, 2008, at 106, 151.

110. It was the repo lenders who had the last word on whether Bear had market credibility:

The numbers, scribbled out on a yellow legal pad, told the story . . . A full $\$ 30$ billion or so of repo loans would not be rolled over the next moming. They might be able to replace maybe half that in the next day's market, but that would still leave Bear $\$ 15$ billion short of what it needed to make it through the day. By seven [that night] it was obvious that they had only two options: an emergency cash infusion or a bankruptcy filing the next day.

Id. at 152 .

111. See Cecchetti, supra note 92 , at 11.

112. See Cox Letter, supra note 12, at 3 ("Notwithstanding that Bear Stearns continued to have high quality collateral to provide as security for borrowings, market counterparties became less willing to enter into collateralized funding arrangements with Bear Stearns.").

113. Cecchetti, supra note 92 , at 12-13.

114. Id. The Fed added three new credit facilities after the effects of the credit crunch beginning in 2007 became more serious:

The three newbies - the term auction lending facility, the primary-dealer credit facility, and the 
they suggest that the Fed, at least, has come to terms with the liquidity dynamics of the new credit market.

Before considering the Fed's alternative interventions, let me review the liquidity axioms discussed so far. First, a firm can enhance its own liquidity (its funding liquidity) by drawing on the market liquidity of its assets, for example by extracting the collateral value of a security in the repurchase market. ${ }^{115}$ Conversely, when market liquidity for an asset evaporates (as it began to for corporate credit in the summer of 2007), the liquidity of a firm that had come to depend on liquifying transactions in the open market suffers too. This downside of the axiom is illustrated by lenders whose pipelines got clogged with loans that the secondary market rejected, threatening banks that had "originated-todistribute" with the prospect that they had, unwittingly, increased their "warehousing risk" by being stuck with loans of deteriorating quality. ${ }^{116}$ Second, trading liquidity in the secondary market for a firm's liabilities (as suggested by narrow bid-ask spreads or trading volume) may not be a proxy for the credit quality of the liability or even the borrower's own liquidity, because a borrower's fundamental liquidity can decline by excessive borrowing even as market liquidity for its liabilities increases. ${ }^{117}$ This is an example of the "beauty contest" effect produced when a secondary trading market creates a forum for speculative euphoria that may not be justified by the traded liability's anticipated cash flow; this axiom describes so much of what has happened recently that it should really be the moral of this particular chapter of credit history. Third, insofar as demand for financial products is leveraged (by borrowing), cuts in borrowing reduce demand for these products, which may have ripple effects on the liquidity of other firms. ${ }^{118}$ An example is what happened to investment banks who felt a market liquidity whiplash after cutting credit to their hedge fund clients. ${ }^{119}$ These are just three aspects of what is surely a more complex feedback loop between firm and market liquidity.

The Fed's alternative interventions respected this axiomatic understanding, particularly the first axiom about how market liquidity can enhance a firm's own liquidity. The thrust of the collateral rules for the Fed's new credit facilities was to boost the market liquidity of certain classes of collateral so that firms could enhance their own funding liquidity by extracting the collateral value of their securities holdings. ${ }^{120} \mathrm{By}$

term securities lending facility - total more than half-a-trillion dollars, with more if needed. Much of this money is available not only to commercial banks [Fed members], but also to investment banks, which normally aren't allowed to borrow from the Fed.

Allan Sloan, On the Brink of Disaster, FORTUNE, Apr. 14, 2008, at 78, 82 (analyzing federal regulatory efforts to stabilize the credit market by adding liquidity).

115. See supra notes 55-63 and accompanying text.

116. Peter Praet \& Valerie Herzberg, Market Liquidity and Banking Liquidity: Linkages, Vulnerabilities and the Role of Disclosure, FIN. STABILITY REV., Feb. 2008, at 95, 95-107 (explaining links between market and firm liquidity); see also id. at 101 ("Banks relying on securitisation funding had to seek alternative funding sources, as warehousing risks materialised." (citation omitted)).

117. See supra notes 66-73 and accompanying text.

118. See supra notes $107-08$; infra notes $120,347-49$ and accompanying text.

119. See supra notes $107-08$ and accompanying text.

120. This is the same liquidity result produced by the collateral rules of the Term Auction Facility (TAF-a credit window for commercial banks), the Term Securities Lending Facility (TSLF-a securities lending window for primary dealers), and the Primary Dealer Credit Facility (PDCF-a credit window for primary dealers). "TAF loans must be over-collateralized by at least a factor of two, but in reality the Fed is taking 
choosing to go home with a very ugly contestant, the Fed loan for Bear also promoted market liquidity by creating a miniature secondary market for the collateral (this time including private structured credit products) that, like the collateral rules of these facilities generally, boosted the market value of the securities. At the same time, by shoring up Bear's liquidity this way, the loan propped up Bear, which could then stay in the game and contribute its own demand (albeit leveraged demand) for investment assets, thereby adding price support to the credit market. In the options metaphor that has become popular for this type of transaction, it is said that the Fed let Bear exercise the Bernanke "liquidity put" against the Fed, financial short-hand for the idea that by borrowing against collateral-as Bear did-it transferred risk in the collateral to the Fed. ${ }^{121}$ If Bear defaults, then the Fed has stepped into its shoes as the owner of the collateral-all the more since the loan is nonrecourse. ${ }^{122}$ Indeed, the Bear deal was probably the last major example of bargaining power shifting from the lender (the Fed) to the borrower (Bear) because the tide has turned in favor of lenders again.

\section{LEVERAGE AND LIQUIDITY LOOPS IN THE FINANCIAL SECTOR}

Soon before the 2007 summer credit crunch, a Fed official noted that "there is little reason to believe we have entered a new era of permanent stability." ${ }^{123}$ Hyman Minsky

collateral at a price that is almost surely above its actual market price . . . [This] helps to address potential liquidity constraints on individual institutions ...." Cecchetti, supra note 92, at 15 (citation omitted). Both the TSLF and the PDCF boost a borrowing primary dealer's own liquidity by accepting as collateral (and thereby increasing the market liquidity of) securities that have not typically qualified as collateral for loans from the Fed. Id. at 16-19; see also Geithner Statement, supra note 9, app. 1, at 1 (explaining how lengthening loan terms, expanding the range of eligible collateral, reducing interest costs, and lending to new counterparties enhances market liquidity).

121. A put is an option which gives the holder the right (but not the duty) to sell an asset for a fixed price. BARRON's DICTIONARY OF BANKING TERMS 330-31 (1997). In this context, those who pledge structured credit products as collateral for a loan from the Fed are "long" the put, while the Fed is "short" the put because it stands ready to bear the risk of the collateral by lending. This is the same kind of put that bank owners exercise against the Federal Deposit Insurance Corporation (FDIC) when they walk away from an illiquid bank, forcing the FDIC to step into their shoes as owner of the bank's assets (and obligor on insured deposits). Moral hazard arises because the Fed and the FDIC come to own the collateral only when the borrower can no longer bear its downside risk. Unlike an ordinary equity investor, neither the Fed nor the FDIC get any of the upside risk from this collateral that has been extracted by the borrowers before they exercised their puts. In private markets, the writer of the put collects a premium for making the put promise. Although Bernanke is the Fed Chairman who now has to perform on these puts, you could say that it was Alan Greenspan who collected the premiums on writing them.

122. The Fed's franchise right over printing money gives it, literally, a "money machine": in addition to fees charged for FedWire and other banking services, the Fed funds itself through seignorage--the profit spread captured by printing money. "[S]eignorage accrues to the Federal Reserve System, but because the Federal Reserve remits its profits to the U.S. Treasury, the seignorage revenue ends up with the federal government." Owen F. Humpage, An Incentive-Compatible Suggestion for Seignorage Sharing with Dollarizing Countries 5 (Fed. Res. Bank of Cleveland, Policy Discussion Paper No. 4, 2002), available at http://papers.ssrn.com/ abstract $=1025458$. Before this transfer to the U.S. Treasury, the Federal Reserve banks cover their expenses and pay their shareholder banks a statutory cumulative dividend of $6 \%$ annually. 12 U.S.C. $\S 289$ (a)(1) (2006). The loan to Bear is another example of the way the bargaining power shifted from lenders - in this case the Fed-to borrowers (like Bear), although we worry less about the Fed's own creditworthiness because its monopoly right to print money makes it the ultimate deep pocket.

123. Timothy Geithner, President \& C.E.O., Fed. Reserve Bank of N.Y., Liquidity Risk and the Global 
would have chuckled because he saw financial instability as a fact of life in a capitalist economy like ours. Timely and relevant now, his theory supports three working propositions about the credit market's current liquidity dynamics discussed in the previous Part. First, as noted above, identifying the causal relationships between leverage, the firm's liquidity, and the trading liquidity for a firm's liabilities is a prerequisite for understanding the current credit market. Subpart A starts with Minsky's analysis of financing, which does an excellent job of classifying borrowing in terms of its propensity for future risk both to borrowers and markets.

Second, during the past decade, changes in the institutional structure of corporate credit have increased the fragility of the financial sector, vindicating his financial instability thesis and intensifying the liquidity dynamics discussed above. Subpart B does this analysis for four major trends that have contributed to riskier forms of financing: the growing desensitization to leverage, the popularity of floating-rate credit, the rise of nonbank lenders, and the growth of secondary credit markets. Finally, Minsky pointed out that these movements toward financial fragility were a recurring dynamic of financial capitalism. Subpart C plots Minsky's view of financial cycles-which is enjoying a revival today (although often without attribution) through an emerging consensus on the role of financial firms in liquidity cycles - in an arc of credit modeling that begins with New Deal approaches to business cycles.

\section{A. Minsky: The Ongoing Relevance of Liability Financing}

Minsky elaborated much of his theory as part of his project of reinterpreting the work of John Maynard Keynes on financial markets. ${ }^{124}$ For much of his career, Keynes had worked within the then dominant paradigm for financial and monetary policy. ${ }^{125}$ Known as the "quantity theory of money," it explained the amount of money in circulation in terms of "economic equilibrium." 126 Over time, Keynes provided an alternative explanation, saying that investor preference for liquidity influenced the money supply and that uncertainty pervaded the production and circulation of money. ${ }^{127}$ In other

Economy: Remarks at the Federal Reserve Bank of Atlanta's Financial Markets Conference on Credit Derivatives at Sea Island, Georgia (May 15, 2007), available at http://www.ny.frb.org/newsevents/speeches /2007/gei070515.html ("[T]here is little reason to believe we have entered a new era of permanent stability. Financial innovation and global financial integration do not offer the prospect of eliminating the risk of asset price and credit cycles, of manias and panics, or of shocks that could have systemic consequences.").

124. HYMAN P. MINSKY, JOHN MAYNARD KEYNES, at v (1975) [hereinafter MINSKY, KEYNES].

125. "His work in economics during the twenty-five years prior to 1935 , while novel in detail, often subject to controversy, and typically deviating from the conventional wisdom when discussing public policy, was, on the whole, in the discipline's mainstream: his criticisms were within but not of standard theory." $I d$. at 2.

126. Minsky noted:

The fundamental propositions of the quantity theory of money are that for positions of equilibrium, money is neutral, in the sense that relative prices, incomes, and output do not depend upon the quantity of money; that the general level of prices is determined by the quantity of money; and that a decentralized economy is fundamentally stable. Keynes's attitude, prior to The General Theory, was that these quantity-theory propositions were basically valid, but that the theory was vague and imprecise about the mechanisms and processes by which the long-run results were achieved ....

Id.

127. Specifically: 
words, holding liquidity (as in cash) helped to mitigate the uncertainty of future states of the world; the aggregate effect of these liquidity preferences, said Keynes, influenced the amount of money in and out of circulation. ${ }^{128}$ The economics establishment of Keynes's day accepted his ideas, but selectively rejected elements deemed too radical, like the central role of uncertainty, the cyclical nature of a capitalist economy, and the importance of the institutional structure of financial relations. ${ }^{129}$

Minsky sought a more robust interpretation of Keynes's work, particularly its emphasis on the institutional structure of financial markets. ${ }^{130}$ As he put it, "[i]gnoring financial markets while trying to explain the behavior of advanced capitalist economies is like ignoring the Prince in casting a production of Hamlet." ${ }^{131}$ So Wall Street and The City (a reference to the London capital market) figure prominently in his work. ${ }^{132}$ Coming of age intellectually in the 1950s, Minsky learned economics before the rise of deductive financial models that assumed away how firms and markets actually behaved for the sake of reaching elegant mathematical conclusions. His doctoral dissertation at

The General Theory marked a sharp break with this earlier position on the quantity theory. Keynes attacked with great gusto and obvious relish the logical and empirical foundations of traditional economics .... He introduced novel tools of analysis, such as the consumption function and the liquidity preference, and employed concepts unfamiliar to mainstream economists, such as uncertainty.

Id.

128. Liquidity has special value in an uncertain world:

[People] recognize that predictions of both future earnings and future liabilities are unreliable. Faced with the unknowability of the future, economic actors view money differently from the way they view other goods. Money is a liquid store of value that can be used to satisfy contractual commitments if earnings fail to meet, or liabilities exceed predictions.

See Pouncy, supra note 22, at 543-44 (citation omitted).

129. "The substance of what was neglected in the development of the synthesis [of Keynes into mainstream economics] can be grouped under three headings: decision-making under uncertainty, the cyclical character of the capitalist process, and financial relations of an advanced capitalist economy." MINKSY, KEYNES, supra note 124, at ix. Avoiding these elements made the General Theory easier to swallow: "That is, once uncertainty and the cyclical perspective were ignored, which is a tall order, [Keynes's] new theory could be phrased in terms of familiar constructs, first modified and then put together in a novel manner." Id. at 60 . The introduction in the Banque de France's recent collection of 15 essays on liquidity highlights these very three issues: the role of uncertainty, liquidity, and the structure of the finance sector. Liquidity, supra note 15, at ii-iii. Somewhat ironically, a friend and colleague of Minsky notes that towards his final days (he died of cancer in 1996), he proposed his own synthesis of his economic approach to neoclassical economics. "Minsky's reconciliation was pointing to the fact that his brand of economics augments and transforms standard theory by stressing the need to understand market processes in their institutional and historical context." Charles $\mathbf{J}$. Whalen, A Minsky Moment: Reflections on Hyman P. Minsky (1919-1996), 42 J. ECON. ISSUES 249, 252 (2008) (citation omitted).

130. HYMAN P. MNSKY, STABILIZING AN UNSTABLE ECONOMY 5 (1986) [hereinafter MINSKY, UNSTABLE ECONOMY].

131. Hyman P. Minsky \& Mark D. Vaughan, Debt and Business Cycles, Bus. ECoN., July 1990, at 23, 24. Minsky noted that "in the various versions of the neoclassical synthesis the financial mechanism, which is central to Keynes's interests, is almost always treated in a most truncated fashion." MINSKY, KEYNES, supra note 124 , at ix.

132. See, e.g., MINSKY, UNSTABLE ECONOMY, supra note 130, at 223-53 (emphasizing how liability management by commercial and investment banks influences the money supply and financial stability in a capitalist economy). 
Harvard focused on macroeconomics but it had strong elements of microeconomic thought too, insofar as it pointed to the special role played by finance firms in the economy overall. ${ }^{133}$ Minsky defined financing "functionally" in terms that transcend whether or not a firm is organized as an insured depository institution or not, making his approach especially relevant as nonbank lenders become active in the credit market. ${ }^{134}$

In particular, the liability structure of these finance firms-how they used debt to finance themselves--was central to his theory of instability. ${ }^{135}$ The most comprehensive survey that I know of that analyzes patterns of liability issuance by firms during the period in which Minsky published his early work does not include the financial sector, so comparing across time periods is difficult. ${ }^{136}$ In the intervening years since Minsky published his research, though, the finance sector (along with research about the finance sector) has grown substantially, so much so that research literature examines the "financial accelerator" of the economy. ${ }^{137}$ The premise behind this literature-that the financial economy can at times lead the real economy-is very much in line with Minsky's emphasis on firms that borrow to lend. Indeed, Minsky's doctoral thesis anticipated the insight that not only did the firm's liability structure matter in terms of liquidity generally but that it helped to determine the type of assets that the firm would

133. It is this general insight about the importance of market structure for secondary liability markets which later parts of this Article develop: "The bulk of Minsky's thesis turns out to be an extended examination of the consequences of financial liabilities on the investment behavior of firms." Jan Toporowski, Methodology and Microeconomics in the Early Work of Hyman P. Minsky 5 (Levy Econ. Inst. of Bard Coll., Working Paper No. 480, 2006).

134. As he notes, the business of banking is - effectively-dispersed across several financial intermediaries: "The line between commercial banks[,] . . . other depository thrift institutions, miscellaneous managers of money (like insurance companies, pension funds, and various investment trusts), and investment bankers is more reflective of the legal environment and institutional history than of the economic function of these financial institutions." MINSKY, UNSTABLE ECONOMY, supra note 130, at 223.

135. It is the opposite of what the Modigliani-Miller approach suggests: "We must develop economic institutions that constrain and control liability structures, particularly of financial institutions and of production processes that require massive capital investment." Id. at 5 (emphasis added); $c f$. Francisco Modigliani \& Merton H. Miller, The Cost of Capital, Corporate Finance, and the Theory of Investment, 48 AM. ECON. REV. 261,268 (1958) (discussing the nature of bonds in determining relative share prices).

Any decision [by a firm] to acquire real capital assets, as he was keen to emphasize, bequeaths the firm with a certain liability structure that shapes its balance sheet for a long time to come. This liability structure is either validated or contradicted by future events, with possibly dire consequences as firms' expected returns might never be realized.

Erturk, supra note 68 , at 2.

136. Railroads, public utilities, and other industrial fields were the three major classifications of bonds. Each major group was further divided into minor groups, of which the manufacturing groups in the industrial classification were the most differentiated. W. Braddock Hickman, Trends and Cycles in Corporate Bond Financing 1-2 (Nat'l Bureau of Econ. Research, Inc., Occasional Paper No. 37, 1952).

137. One line of recent research views the financial sector as a "financial accelerator" of the business cycle:

Over the 1990s, the knowledge base about finance and its linkages to the real economy grew. Financial factors are now understood to amplify and propagate changes in the business cycle. Decisions about capital structure and corporate strategy coincide into what has come to be known as the "financial accelerator" of the economy as a whole ....

GlenN Yago \& SusanNe TRimbath, Beyond Junk Bonds: ExPanding High Yield Markets 124-25 (2003) [hereinafter YAGO \& TRIMBATH, BEYOND JUNK BONDS] (citation omitted). 
hold. ${ }^{138}$ It was in this context that he developed the financial instability thesis, the idea that the financial sector-as a whole - had a tendency to borrow itself into periods of financial fragility that would culminate in acute episodes of financial instability. 139

Others have observed that financial instability always involves debt speculation, but what Minsky added was a method for classifying borrowing based on how it impacts the borrower's liquidity due to the borrower's future needs to refinance. ${ }^{140}$ Granted, many forces can make the financial sector more fragile, but Minsky's method diagnoses how specific financing deals can set the stage for both funding and market liquidity problems later. It also has the virtue of explaining sectoral trends by starting with an example of how an individual firm finances itself and extrapolating from there to suggest sector-wide trends. (Minsky did not provide many extended analyses of particular liability markets, however.) $)^{141}$

Taking loans as a fact (not as a modeling assumption), he noted that a borrower pays back both principal and interest at different points during a loan. ${ }^{142}$ Making what is really a Coasian move, Minsky divided loans into three types, arranged from minimum to maximum default risk: hedged financing, speculative financing, and Ponzi financing, each of which has distinctive liquidity dynamics. ${ }^{143}$ Below, I set out each type before using the three-part scheme to analyze the liquidity dynamics from the previous Part. Before considering the three types, let me point out that Minsky focuses on cash flow, specifically whether cash inflows can meet payment commitments for a financing arrangement. So he does not address other dimensions of borrowing that have material legal and economic consequences, for example, whether borrowing is recourse or collateralized. My reading of his analysis, though, suggests that he has in mind uncollateralized, recourse debt for two reasons: first, because a borrower can walk away from a nonrecourse obligation, failing to meet a payment obligation does not directly affect the borrower's liquidity (although it may have dramatic consequences for its

138. Id.

139. Id.

140. See John Kenneth Galbraith, A Short History of Financial Euphoria 16 (1993) (“All crises have involved debt that, in one fashion or another, has become dangerously out of scale in relation to the underlying means of payment."); see also id. at 76-77 (discussing the role of margin leverage in contributing to the $1929 \mathrm{crash}$ ). Legal scholars have cited Minsky generally for his thesis about financial instability, but the recent events in the credit market make the specifics of his classification of borrowing timely. See Frank Partnoy, Why Markets Crash and What Law Can Do About It, 61 U. PITT. L. REV. 741, 755-56 (2000) (identifying Minsky's financial instability thesis as a precursor to Charles Kindleberger's economic history of financial market crashes). Partnoy situates Minsky as a source of economic arguments that financial markets crash because of "cognitive error" on the part of individual borrowers and lenders in the market. See id. at 75455 (comparing theories based on cognitive error with those based on moral hazard and information asymmetry).

141. For example, he points out that the U.S. Treasury is a speculative, rather than hedge borrower because of its tendency to refinance maturing principal obligations: "The Treasury with its large amount of outstanding short-term bills is, in effect, a speculative unit, as are commercial banks. In the sense the term is used here, any financing of long-term assets with short-term debt makes the borrower a speculative unit." Minsky \& Vaughan, supra note 131 , at 26 . Given the doubling of U.S. public debt in the last 5 years, it might be more accurate to see the Treasury as a Ponzi borrower.

142. MINSKY, UNSTABLE ECONOMY, supra note 130, at 206-07 ("Hedge-financing units and their bankers . . expect the cash flow from operating capital assets (or from owning financial contracts) to be more than sufficient to meet contractual payments commitments now and in the future.").

143. See infra notes $155-58$ and accompanying text. 
creditworthiness going forward); and, second, since collateral mitigates a borrower's ultimate exposure to in personam liability, uncollateralized borrowing poses the greatest risk to a borrower's liquidity. In contrast, with collateralized, nonrecourse financingsuch as the discount window loan to Bear and JP Morgan - the risk stays with the lender, who can look only to the market value of the collateral for repayment.

In a hedged borrowing, the borrower expects the cash flow forthcoming from investment of the loan proceeds to be enough to cover both the principal and interest due in each of the loan's payment periods. ${ }^{144}$ That is, the borrowing is "self-liquidating" in the old-fashioned sense used by the Fed to identify collateral acceptable for rediscounting. ${ }^{145}$ So long as all borrowing is of the hedged type, there is little financial fragility and, presumably, slower growth since, in effect, the borrower is on a gold standard of its own: it will borrow only when its assets can back the credit. Paying down principal reduces the leverage attributable to hedge financing. A strict reading of Minsky suggests that hedged financing is always fixed rate, so that rising interest rates do not increase the interest costs to the borrower or jeopardize its liquidity, although the borrower "loses" if rates drop, especially if the borrower has floating-rate assets. ${ }^{146} \mathrm{On}$ the other side of the loan, the lender in a hedged borrowing has less default risk (although, conversely to the borrower, the value of the loan to the lender will deteriorate if rates rise).

A loan is "speculative," the second of Minsky's borrowing types, when the proceeds of its investment will produce enough cash flow to pay the interest as it becomes due but not the principal as it matures. ${ }^{147}$ To pay principal, the borrower will have to refinance, risking higher borrowing costs from market-wide increases in interest rates or a decline of its own creditworthiness. A special instance of financial euphoria, the liquidity euphoria facilitated by leverage make these risks seem distant. ${ }^{148}$ The speculative lender also risks more, particularly if it has waived debt covenants. And, a speculative loan may "cost" a commercial bank lender more in terms of regulatory capital, a cost that increases with the risk of the loan or the borrower. ${ }^{149}$ To the lender, too, these costs can seem

144. MINSKY, UNSTABLE ECONOMY, supra note 130, at 206-07 ("Hedge financing units and their bankers ... expect the cash flow from operating capital assets (or from owning financial contracts) to be more than sufficient to meet contractual payments commitments now and in the future.").

145. Self-liquidating paper refers to "paper which is issued or drawn under such circumstances that in the normal course of business there will automatically come into existence a fund available to liquidate each piece of paper, that fund being the final proceeds of the transaction out of which the paper arose." See FEDERAL RESERVE LENDING HISTORY, supra note 3, at 31 (quoting a 1968 Bulletin of the Federal Reserve).

146. MINSKY, UNSTABLE ECONOMY, supra note 130, at 208. ("A hedge-financing unit is vulnerable only to cost escalation or revenue declines .....). One could also imagine "synthetic" hedged financing using an interest-rate swap to immunize the borrower from a floating rate. Interest-rate swaps had already developed when Minsky introduced his borrowing classification. For a discussion of floating-rate debt, see infra notes $182-89$ and accompanying text.

147. MINSKY, UNSTABLE ECONOMY, supra note 130, at 207 ("Speculative finance involves the short [term] financing of long [term] positions. Commercial banks are the prototypical speculative financial organization.").

148. Id.

149. Arguably, even a nonbank lender might face a market capital charge for a risky loan just as a commercial bank might face a regulatory capital charge, but the balance sheets of depository institutions are, presumably, more transparent to regulators through the call report than is the balance sheet of a generic nonbank lender. Every quarter, commercial banks must file a Report of Condition and Income that summarizes their balance sheet, income, and cash flow positions, known colloquially as a "call" report. See Fed. Deposit Ins. 
remote so long as the lender anticipates offloading the loan in the secondary market, as has become common.

The cash flow from a Ponzi borrowing, the third of Minsky's types, will finance neither the interest nor the principal due on the loan as these payments become due. ${ }^{150}$ Moreso even than with the speculative loan, the borrower expects to re-enter the market to refinance. ${ }^{151}$ In Ponzi arrangements, the likelihood of illiquidity or insolvency increases over time. ${ }^{152}$ Although the concept of Ponzi financing is popularly associated with fraud, the borrower may not, however, specifically intend to cheat the lender; rather, a Ponzi borrower may only be uncommonly bullish about the prospects for future refinancing. ${ }^{153}$ Moreover, whether a financing arrangement is hedge, speculative, or Ponzi remains subject to waiver and discretion by the lender. ${ }^{154}$

Although it does not take into account whether debt is recourse or collateralized, Minsky's three-part scheme says much about how borrowing affects the firm's liquidity. ${ }^{155}$ Importantly, the scheme shows how borrowing exposes the firm to funding

Corp., Reports of Condition and Income Forms and User Guides, http://www.fdic.gov/regulations/resources/ call/Index.html (last visited Jan. 20, 2009).

150. Whether or not the borrower and lender make this assumption explicit, Ponzi borrowing assumes future borrowing to meet the contractual repayment obligations on the debt: "[W]hereas the short-period cash flows for speculative units are such that financing costs do not increase outstanding debt, for Ponzi finance units financing costs are greater than income, so that the face amount of the outstanding debt increases: Ponzi units capitalize interest into their liability structure." MINSKY, UNSTABLE ECONOMY, supra note 130, at 207.

151. Even though subprime borrowers who had taken out floating-rate loans with low "teaser" rates knew that the rates on their loans would rise eventually, the prospect of refinancing at the reset debt to avoid the rate hike would have seemed likely insofar as these borrowers also assumed that real estate prices would also rise.

152. MINSKY, UNSTABLE ECONOMY, supra note 130, at 208-09.

Thus, the cash flows that must be earned for the financial commitments to be fulfilled become greater, and the equity-debt ratio deteriorates. The conditions for full debt validation become stricter, and the shortfall of earnings or the rise in interest costs that makes it highly unlikely that payment commitments will not be fulfilled becomes smaller.

Id.

153. Id. at 208.

154. Id.

Debt restructuring is often an effort to transform speculative into hedge financing, and concessions in financing terms by lenders may be made in an effort to transform Ponzi units into speculative units. The refinancing and restructuring of debt of entities as diverse as Chrysler, New York City, Baldwin-United, and Brazil that have taken place in the past decade are efforts to shift the financing of particular organizations toward the hedge side of the spectrum of financing relations.

Id.

155. The financier who coined the term "Minsky moment" claims that the use of (effectively) nonrecourse liability to finance home purchases with no money down by the borrower amounted to a fourth type of financing--"Ponzi squared":

Let me define for you what Ponzi squared is. In the mortgage market in 2005-06 and early 2007, the marginal loan or debt unit actually was not a loan. The marginal loan unit was no money down, no documentation of ability to pay, with a teaser rate and negative amortization. Think of those four characteristics. That actually isn't a loan. It's a package of an at-the-money call option (to buy the house at the current market price) and an at-the-money put option (to sell the house back at that price)-for free .... When there is zero down, that creates the next step beyond Ponzi. The Ponzi unit isn't defined by the terms of whether or not the borrower has skin in the game; it's [defined by] the deficiency of cash flow to pay interest or amortize the principle. It's agnostic, essentially, on the 
liquidity risk from future refinancing. Hedged borrowing has little of this risk because the firm uses only internal cash flow to service the debt. In contrast, speculative and Ponzi debt liquify the borrower provisionally (through inflow of cash), but they encumber its funding liquidity with future claims to repayment greater than the expected cash flow from the use of the loan proceeds. ${ }^{156}$ The speculative borrower must contend with refinancing to fund maturing principal payments. The Ponzi borrower must do so for both maturing interest and principal payments. In this case, the borrower's funding liquidity involves a form of "leveraged liquidity."

Second, Minsky's classification shows how market liquidity can also be leveraged by firm borrowing insofar as demand for assets is financed by borrowing. A lender originates a loan and then sells it in the secondary market. Insofar as the secondary market purchaser of the loan finances its acquisition with borrowed funds, demand for the loan in its secondary market is also leveraged. This form of leveraged liquidity helps prop up market liquidity for the loan. Also, borrowing on speculative and Ponzi terms probably encourages investment by the borrower in similarly risky assets (that is, speculative and Ponzi ones) because only they promise the kind of return needed to repay the borrowing. Consider, for example, the speculative assets in which savings and loans invested when the Regulation Q cap on what they could pay out in interest was lifted. ${ }^{157}$ Understanding this loop between borrowing and loan trading may predispose the lender to make speculative and Ponzi loans so as to build up frothy liquidity in the trading market.

The liquidity axioms described in the first Part apply whether a borrowing is hedged, speculative, or Ponzi, but the tendency towards financial instability is greater for a firm that has borrowed at speculative or Ponzi terms. When such a firm faces a maturing payment of interest or principal, the borrower must either refinance or sell an asset to fund the payment. Refinancing is fine so long as the origination and credit trading

issue of skin in the game. A unit is Ponzi squared if it has all the characteristics of a Ponzi unit and you've got no skin in the game, because then you have something extremely valuable being given to the speculator for free: an at-the[-]money call and at-the-money put. None of us would pass up that kind of thing.

Paul A. McCulley, A Reverse Minsky Journey: Address Before the 17th Annual Hyman P. Minsky Conference on the State of the U.S. and World Economies 11 (Apr. 17, 2008), available at http:/www.levy.org/pubs/ pro_Apr_08.pdf. To this excellent observation I would only add that, even with $100 \%$ home financing, retail borrowers do, in fact, bear significant transaction and reputational costs, such as damage to creditworthiness, on such loans.

156. Pouncy notes that on the upside of the cycle the firm is becoming less liquid as asset values are rising:

This period of euphoric expectations leads to increased investment, improved corporate earnings, and lower unemployment. These conditions validate the recent use of speculative finance and the maintenance of higher debt-to-equity ratios. However, the rise of debt-to-equity ratios results in less liquidity. Firms go to the debt market, which is now responding to increased demand, with higher interest rates.

Pouncy, supra note 22, at 567 (citations omitted).

157. Fred E. Case, Deregulation: Invitation to Disaster in the S\&L Industry, 59 FORDHAM L. REv. 93, 9499 (1991) (arguing that repeal of Regulation Q limits exposed savings and loans to competition such that they lost their traditional focus on local lending). "To compete, the S\&Ls had to abandon their traditional functions in search of higher returns from high-risk ventures. Such ventures also fed the gambling urge of the newly powerful S\&L owners." Id. at 97. 
markets continue to escalate, but when this is not the case, the borrower must sell assets. If many borrowers find themselves in this situation at the same time, their liquidating asset sales become, effectively, a bear raid, driving down asset prices, discouraging lenders from refinancing, threatening the liquidity of firms, and leading to extreme liquidity events that show up as "fat tails" but not as foreseeable losses in most financial models. ${ }^{158}$ Leveraged liquidity, then, can engender financial fragility leading to financial instability, even as it seems to be contributing to stability by facilitating exchange. ${ }^{159}$

Contrast this with the opposite of leveraged liquidity: the liquidity produced in a repurchase agreement on "special." 160 In this case, market demand for a less liquid security induces investors to sacrifice liquidity by offering cash as collateral for what is, in effect, a securities loan (reflecting what I earlier called a negative liquidity preference). ${ }^{161}$ It is a fully hedged borrowing in Minsky's scheme, because the liquidation value of the security can cover the loan (and many repos have an extremely short term, i.e., overnight, such that risk is limited by the deal structure itself, as seen earlier in the context of Bear's repo lending problem).

Minsky's theory is cyclical because it predicts that firms individually (and the financial system in the aggregate) will move from the relative safety of hedged financing towards speculative and Ponzi financing arrangements, which promise escalating levels of return. ${ }^{162}$ Indeed, it is the momentum towards speculation that creates the escalating return. ${ }^{163}$ Expressed in terms of Minsky's borrowing types, then, what began to happen in July 2007 was that firms could no longer refinance their speculative and Ponzi

158. It is another example of the link between asset and market liquidity: "Ultimately, however, financial innovation will be unable to generate the profits necessary to service debt. Firms will attempt to sell assets to service debt, and the asset market will become flooded." See Pouncy, supra note 22, at 568 .

159. Adrian and Shin's argument that leverage is procyclical and that market structure creates channels of new contagion is in line with Minsky's argument about how borrowing increases on the upside of the market. ADRIAN \& SHIN, supra note 14, at 1-2.

160. See supra notes 58-63 and accompanying text (describing liquidity dynamics of repurchase transactions); see also supra notes 109-112 (explaining the role of repurchase liquidity during the demise of Bear).

161. See supra notes 58-63 and accompanying text (describing liquidity dynamics of repurchase transactions); see also supra notes 109-112 (explaining the role of repurchase liquidity during the demise of Bear).

162. MINSKY, UNSTABLE ECONOMY, supra note 130, at 219-20.

Any transitory tranquility is transformed into an expansion in which the speculative financing of positions and the external financing of investment increase. An investment boom that strips units of liquidity and increases the debt-equity ratios for financial institutions follows. Margins of safety are eroded even as success leads to a belief that the prior-even the present-margins [of safety] are too large.

Id. This is what led to the summer credit crunch in 2007.

163. Again, Paul McCulley says it well:

We all know the three stages of the forward journey. You start with hedge units, then proceed to speculative units, and then, finally, to Ponzi units. We've all taught it; we all know it. That's the forward journey .... The reason you make that journey is that the very act of moving from one step to the next drives up asset prices and therefore validates the risk-seeking behavior. As long as asset prices are going up, it covers all sins. But you reach a point where there is a fundamental evaluation barrier that you can't get over, and that creates the meltdown.

McCulley, supra note 155 , at 10 . 
financing. ${ }^{164}$ A report of the European Central Bank on leveraged buyout financing by European banks (issued three months before the summer 2007 credit crunch) suggested that banks anticipated the unsustainability of their clients' borrowings:

Interestingly, some market participants [(European banks)] tend to admit that some of the LBO deals currently being financed are characterized by capital structures that are known to be unsustainable in the long term, on the assumption that the deals can be refinanced on more favourable terms in the near future. ${ }^{165}$

That is, these bankers knew that they were engaging in speculative and Ponzi lending that would fall apart when the bubble burst. The market's validation of what these bankers expected has led some financial commentators to speak of the credit contraction as a "Minsky moment." 166 These commentators are correct; but just as Minsky had objected to the selective incorporation of Keynes's General Theory, one must remember that seeing only the acute contractions as "Minsky moments" misses the more basic point: it is the liquid moments leading up to the contraction-specifically speculative and Ponzi deals put on during stable periods-that resolve into financial instability. The next section looks at some of the major trends in the corporate leverage markets that explain why financiers like the European bankers mentioned above have become so blasé about speculative and Ponzi financing.

\section{B. Market Structure Shifts Towards Ponzi Finance}

I emphasize four trends that have contributed to speculative and Ponzi financing, each of which illustrates Minsky's theory about how borrowing contributes to cyclical financial instability. First, like Dr. Strangelove with the bomb, we have gotten used to speculative and Ponzi borrowing, both in our personal finances and as stewards of firms, despite the risks so engendered. Second, during the recent period of low volatility and easy money, firms borrowed more at floating rates, exposing themselves to the kind of interest-rate risk that can convert speculative into Ponzi financing and drive Ponzi financing into default. Third, increasing numbers of nonbank lenders now originate and trade corporate credit. While portfolio lenders like commercial banks have special training, institutional support, and regulatory incentives (such as they are) to act as

164. But see Paul Davidson, Is the Current Financial Distress Caused by the Subprime Mortgage Crises a Minsky Moment? Or is it the Result of Attempting to Securitize Illiquid Noncommercial Mortgage Loans?, $30 \mathrm{~J}$. POST-KEYNESIAN ECON. 669, 669-70 (2008). Davidson concludes that even residential subprime mortgages should be viewed as a form of hedge (rather than speculative or Ponzi) finance because a reasonable consumer borrower would realize that the stiff pre-payment penalties and the borrower's own meager creditworthiness would make refinancing of the loan nearly impossible. I have two objections to this good argument. First, Minsky's theory suggests that speculative euphoria keeps reasonable borrowers from appreciating such a fact. Second, even if this is a persuasive construction of hedge finance for retail borrowers, it probably does not apply with equal force to the commercial borrowers that are the subject of this Article because these borrowers have more experience as repeat players with refinancing.

165. EUROPEAN CENT. BANK, LARGE BANKS AND PRIVATE EQUITY-SPONSORED LEVERAGED BUYOUTS IN THE EU 39 (2007), available at http://www.ecb.int/pub/pdf/other/largebanksandprivateequity200704en.pdf.

166. The first ones to spot the Minsky cycle at work were Nouriel Roubini, see supra note 26, George Magnus, see infra notes 219, 222, Edward Chancellor, see supra note 90, and Paul McCulley, see supra notes 155,163 . Since then, Minsky has almost joined the mainstream. 
gatekeepers for risky credit, nonbank lenders have an appetite for more risk, thereby paving the way for firm and market liquidity dynamics that come with speculative and Ponzi products. Finally, secondary markets for credit products have intensified each of these three factors: liquid secondary markets reassure lenders that they can dump a risky credit product and these markets have made it easy for nonbank firms to enter the credit business, two factors which, together, make it easier for risky borrowers to get credit. ${ }^{167} \mathrm{I}$ take each trend in turn below.

\section{Desensitization to Leverage}

In his wry history of credit expansion, James Grant traces how U.S. borrowers became "leverage-friendly." 168 Credit was limited in the 19th and early 20th centuries because firms were reluctant to borrow and financial institutions were reluctant to lend except on a fully (or over-) collateralized basis. ${ }^{169}$ During this period, the gold standard helped to limit credit by linking it to the real economy. ${ }^{170}$ The two major leveragefriendly exceptions to this trend were the margin leverage that contributed to the Great Crash ${ }^{171}$ and public utility holding companies organized along a pyramid scheme. ${ }^{172}$ Willingness to lend and borrow began to increase again after the implementation of New Deal credit programs. ${ }^{173}$ Federal deposit insurance helped to create confidence in

167. The factors are common in the literature on securities and credit market structure. Equity market literature focuses on the identity, function, and interests of institutions (like brokers and proprietary exchanges); how the markets themselves are organized and connect to each other; the depth and liquidity of securities markets when they are spread across a national system; and the role of Commission rules on, among other things, whether consumer protections for retail investors are adequate. The banking market structure literature focuses on the kinds of loan assets that banks hold, how these banks fund themselves, and-crucial given the FDIC's role in bearing residual downside risk for insured deposits-how the mix of bank assets and liabilities affects the liquidity of the institution itself.

168. See generally JAMES GRANT, MONEY OF THE MIND (1992) (tracing the history of credit expansion from the establishment of the Comptroller of the Currency through the 1980s leverage buyout phase).

169. The process of credit expansion took about a century: "For a time in the 1980s, it seemed that anyone could get a loan; that, indeed, almost nobody would be given the opportunity to refuse one. The opposite condition ruled around the turn of the century." Id. at 76.

170. Id. at 7 ("The gold standard, which President Cleveland championed a century ago, was a system for coordinating the growth of money and credit with growth of production and population."). Under the standard, money was a liability of the issuer, i.e., the Treasury or the central bank, which would issue only so much money as was backed by gold in reserve. See MURRAY N. ROTHARD, A HISTORY OF MONEY AND BANKING IN THE UNITED STATES: THE COLONIAL ERA TO WORLD WAR II 104-05, 438 (2002) (giving examples of how the gold standard functioned to reduce inflationary issuance of currency).

171. See GALBRAITH, supra note 140, at 76-77 (showing how margin leverage of 10:1 with margin credit rates as high as 15 contributed to leverage before the $1929 \mathrm{crash}$ ).

172. By establishing a holding company to hold the equity interest in the base company, the enterprise could multiply the number of related entities that could issue preferred stock and debt. The quality of the preferred stock and debt suffered. Although the Public Utility Holding Company Act of 1935 curbed the use of holding company leverage, overall the New Deal began a period of credit expansion and laid the groundwork for the corporate leverage cycle. See generally Robert M. Blair-Smith \& Leonard Helfenstein, A Death Sentence or a New Lease on Life? A Survey of Corporate Adjustments Under the Public Utility Holding Company Act, 94 U. PA. L. REV. 148 (1946) (discussing the Public Utility Holding Company Act).

173. As Grant puts it:

[I]t was in the Depression that the government first offered its guarantee wholesale in lieu of the credit of banks and individuals. The consequences of this epochal change were slow in coming, 
lending, as did other New Deal credit allocation programs that contributed to a "democratization of credit." 174 The public debt grew too, especially during World War II. ${ }^{175}$

Nevertheless, immediately after World War II, a culture of "financial conservatism" contributed to relatively little leveraging by firms and individuals, many of whom might have still remembered the Great Depression. ${ }^{176}$ This would change in the following decades, in part as housing finance programs expanded, making home ownership (at least in formal terms) a reality for more people. Formal homeownership (and mortgage debt) increased from around $60 \%$ in the early 1990 s to more than $65 \%$ by 2001.177 But these owners have extracted (and spent) much of the equity in their homes through refinancing and equity lines of credit. ${ }^{178}$ While formal homeownership has grown, then, the average net equity in homes has decreased. ${ }^{179}$ As one journalist recently put it: "Why do we love leverage so much that it hurts?"180 Part of the reason is that we have become desensitized to the nature of financial risk from leverage. Or, as James Grant recently pointed out in a New York Times editorial that mentioned and relied on Minsky's work: "It would be asking a lot of an ordinary mortal to hew to the literal truth in a mortgage application

awaiting the time when the existing generation of lenders, whom the Depression had scarred for life, were ready to move on. In time, the socialization of risk-in which A paid B's debts, and perhaps Z's--would help to ignite the greatest credit expansion in American annals.

See GRANT, supra note 168 , at 242.

174. The phrase belongs to Arthur J. Morris, an early advocate of credit expansion. Id. at 76 .

175. What was true about the growth of public debt in 1946 continues to be true:

[E]xcept for periods of war (when spending for defense increased sharply), depressions or other economic downturns (when receipts fell precipitously), the Federal budget was generally in surplus throughout most of the Nation's first 200 years. . . . However, the combination of the Great Depression followed by World War II resulted in a long, unbroken string of deficits that were historically unprecedented in magnitude. As a result, Federal debt held by the public mushroomed from less than $\$ 3$ billion in 1917 to $\$ 16$ billion in 1930 and then to $\$ 242$ billion by 1946 .

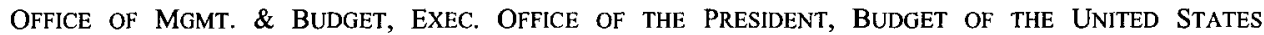
GOVERNMENT, FISCAL YEAR 2009 historical tbls. 5 (2008).

176. Minsky \& Vaughan, supra note 131 , at 24.

Due in large part to the financial structure conservatism induced by the Great Depression and the [price] controls of World War II, extraordinarily low ratios of private indebtedness to aggregate income obtained for much of that period. . . In practical terms, cash flow commitments due to liabilities were very small relative to incomes.

Id.

177. Wenli Li, Moving Up: Trends in Homeownership and Mortgage Indebtedness, Bus. REV. (Fed. Reserve Bank of Phila., Phila., Penn.), First Quarter 2005, at 26, 28, available at www.phil.frb.org/files/br /brq 105wl.pdf.

178. For example, in 2003 homeowners liquidated $\$ 312$ billion in equity through refinancing and equity lines of credit. See Fed. Deposit Ins. Corp., In Focus This Quarter: The U.S. Consumer Sector, http://www.fdic. gov/bank/analytical/regional/ro20044q/na/2004winter_01.html (last visited Jan. 20, 2009) (summarizing trends in economic indicators reflecting consumer income, wealth, and consumption).

179. See Javier Silva, A House of Cards: Refinancing the American Dream, BRIEFING PAPER (Dèmos: A Network for Ideas \& Action, New York, N.Y.), Jan. 2005, at 1, available at http://www.demos.org/pubs/ AHouseofcards.pdf (concluding that much of the cash flow from refinancing and equity lines of credit obtained between 2001 and 2003 went to cover living expenses and to pay down consumer credit).

180. Michael S. Rosenwald, Why We Borrow Until It Hurts, WASH. POST, Mar. 23, 2008, at F1 (comparing leverage by households with corporate and investment leverage). 
when, to the applicant, it seemed as if the money was being offered free."181

\section{Floating-Rate Debt}

A second factor that has contributed to the liquidity dynamics associated with speculative and Ponzi financing is the growth of floating-rate debt, a kind of borrowing that Minsky considered per se speculative because it exposes the borrower to liquidity risk as interest rates change. ${ }^{182}$ Firms must contend with interest-rate risk even when using fixed-rate debt, but floating-rate debt adds risk and complexity. ${ }^{183}$ For example, a climb in LIBOR of 26 basis points (a quarter of a percent) between April 14 and 18 of 2008 increased the annual interest cost to corporate borrowers by about $\$ 18$ billion. ${ }^{184}$ To protect their own risk from drops in LIBOR, lenders have begun to impose floors on LIBOR loans, which means that the borrower faces only the downside risk that rates will rise, while not enjoying the upside risk that LIBOR will fall. ${ }^{185}$ (It is an example of bargaining power returning to lenders.) Granted, firms can "swap" out of floating-rate risk, but these arrangements do not always work because the firm becomes exposed to the swap counter-party's own credit risk, as suggested by recent experiences with monoline bond insurers who have been unable to perform their promises to protect insurance buyers from financial losses from collateralized debt obligations. ${ }^{186}$ And it was the mismatch between variable-rate liabilities and fixed-rate assets that triggered the savings and loan crisis of the 1980s. ${ }^{187}$ These institutions found themselves locked into mortgages and other long-term assets paying only a fixed rate while their liabilitieswhich kept rolling over during the term of their longer-dated assets-became more expensive to service as interest rates rose. ${ }^{188}$ In response, these institutions took increasingly riskier bets in real estate and other investments, a strategy that ultimately led many of them into insolvency. 189

181. James Grant, Paying the Price for the Fed's Success, N.Y. TIMES, Jan. 27, 2008, at A16 .

182. The conclusion predates the growth of interest-rate swaps that let borrowers convert floating-rates to fixed rates, albeit by taking on default risk to the swap counterparty: "[A] unit that borrows at floating rates is engaged in a form of speculative finance, even though at ruling interest rates it is engaging in hedge financing." MINSKY, UNSTABLE ECONOMY, supra note 130, at 208 n.11.

183. For example, if interest rates decline against a fixed-rate liability of the issuer, then the real costs of servicing that liability increase (if interest rates rise against a fixed-rate liability, that debt does "into-themoney" for the issuer, who would have to pay more to secure comparable funding in the then-current market).

184. See Mollencamp et al., supra note 40 (analyzing the impact of climbing LIBOR on $\$ 9$ trillion in corporate borrowing and $\$ 900$ billion in subprime residential debt).

185. Id.

186. Aline van Duyn, Bond Insurers Want $\$ 125 b$ of Cover Wiped Out, Fin. Times (London) (June 22, 2008), http://www.ft.com/cms/s/0/836c7afc-4083-11dd-bd48-0000779fd2ac.html?nclick_check=1 ("Discussions about 'commuting' these insurance contracts, which were sold by bond insurers to banks in the form of credit default swaps, have taken on a renewed sense of urgency amid a rash of ratings downgrades in the bond insurance, or monoline, sector last week.").

187. See Case, supra note 157 , at $98-99$. The borrowing savings and loan faces a liquidity crisis "when rate differentials - the cost of savings account deposits over the return on long-term home mortgage loans--are too often negative. The cyclical nature of real estate markets, increasing short-term interest rates and the long-term character of home mortgage loans are largely responsible for this profit-damaging effect." Id.

188. Id.

189. Id. 


\section{Nonbank Lenders}

A third factor that has contributed to the liquidity dynamics associated with speculative and Ponzi financing is the growth of nonbank financial firms-like investment banks and hedge funds-that originate and trade corporate credit. ${ }^{190}$ Nonbank lenders are now special too. ${ }^{191}$ As noted earlier, nonbank lenders now provide more credit than do depository institutions. ${ }^{192}$ To be sure, commercial banks still lend to highly leveraged borrowers, leading to the occasional slap on the wrist from regulators. ${ }^{193}$ During the last merger financing wave, for example, regulators chided banks for bridge lending, purportedly on an interim basis, although the term lengthened as market liquidity evaporated. ${ }^{194}$ But, like the reptiles that emerged during the Jurassic period, what distinguished this most recent credit cycle was the dominance of nonbank lenders like investment banks, insurance companies, pension funds, hedge funds sovereign wealth funds, and others. For example, the role of hedge funds in originating and trading credit has lead one credit rating agency to announce that a new "credit paradigm" has emerged. ${ }^{195}$

190. Roubini notes the importance of nonbank firms in the "releveraging" of firms:

While the process of releveraging started in the household sector-that is the most financially stretched sector of the US economy-the releveraging more recently spread to the corporate and financial system: in the financial system the rise of hedge funds, private equity and speculative prop desks led to a sharp rise in the financial system leverage. In the corporate sector given the cheapness - until recently - of credit we observed a massive process of switch from equity to debt that took the form of leveraged buyouts, share buybacks and privatization of formerly public companies. This releveraging fed that equity/asset bubble: as expectations of more LBOs occurred equity valuation of many firms went higher and higher .... Notice also that the amount of issuance of low grade corporate bonds (below investment grade "junk bonds") had been rapidly rising in the last few years.

See Roubini, supra note 26.

191. E. Gerald Corrigan, Are Banks Special?, in FED. RESERVE BANK of MINNEAPOLIS, 1982 ANNUAL REPORT 5-18 (1982) (arguing that three things make banks "special": they offer transaction accounts, provide back-up liquidity, and help to implement monetary policy).

192. See supra note 45 (using the Federal Reserve flow of funds to show that nonbank lenders now provide more credit than do depository institutions).

193. Federal interagency guidance from 2001 found that about one-third of all syndicated bank loans involved exposures to borrowers whose leverage (as measured through debt-to-assets, debt-to-equity, cash flowto-total debt or other standard financial ratios) significantly exceeded industry norms for capital structure. The same thing had occurred in the late 1990s when the Federal Reserve complained to member banks underwriting standards for corporate loans. Letter from Bd. of Governors, Fed. Reserve Sys., to the Officer in Charge of Supervision and Appropriate Supervisory and Examination Staff at Each Fed. Reserve Bank and to Each Domestic and Foreign Banking Org. Supervised by the Fed. Reserve (June 23, 1998), available at http://federalreserve.gov/boarddocs/srletters/1998/sr9818.htm. The following year, the Federal Reserve would repeat its advice. Letter from Bd. Of Governors, Fed. Reserve Sys., to the Officer in Charge of Supervision and Appropriate Supervisory and Examination Staff at Each Fed. Reserve Bank and to Each Domestic and Foreign Banking Org. Supervised by the Fed. Reserve (Sept. 28, 1999), available at http://federalreserve.gov/ boarddocs/srletters/1999/sr 9923. htm.

194. Robin Sidel et al., Banks on a Bridge Too Far, WALL ST. J., June 28, 2007, at Cl (reporting that prospective purchasers of buyout debt are objecting to the contractual protections in these bonds, thereby increasing the risk to commercial bank balance sheets).

195. "The growing role of hedge funds in the credit markets without question has introduced greater [funding and market] liquidity in the near term. Of concern would be an ill-timed event that led to a sudden 
Already financial market regulators appreciate that much of commercial banking has shifted from a lend-to-maturity model to one built on an originate-to-distribute approach, in which market liquidity can bear directly on a commercial bank's financial wellbeing. ${ }^{196}$ Less is known about the other side of the convergence - the way that nonbank lenders are evolving towards a business model that derives revenue from originating and trading credit. Unlike commercial banks, these firms lacked a history as portfolio lenders, so many nonbank lenders foundered. So what used to be true about the special vulnerability of commercial banks to funding liquidity risk because of their role in "maturity transformation" of credit may now be true more generally of all firms that borrow to lend, including nonbank lenders. ${ }^{197}$ For example, E*Trade, the third-largest online brokerage firm, came close to declaring bankruptcy in January 2008 because of losses in its loan portfolio, which held mortgage-backed securities. 198 In the years immediately preceding, E*Trade had come to derive as much as $58 \%$ of its revenues from its loan portfolio, rather than from its traditional brokerage business. ${ }^{199}$ And this was part of a general trend. Between 2000 and 2007, several major investment banks increased the proportion of their revenues from (risky) proprietary trading, while their profit margins declined on less risky, fee-based businesses like underwriting, brokerage, and financial advisory services. ${ }^{200}$

Not surprisingly, the Fed has begun to offer liquidity support to nonbank firms, not only through the discount window but also through new credit facilities open to investment banks. ${ }^{201}$ As suggested by this expansion of liquidity support, the institutional liquidity of these nonbank firms has come to matter as much as that of commercial banks. This is so for at least two reasons. Nonfinancial firms turn to them directly to support their own liquidity, so nonbank lenders have become systemic players, earning their

reversal of this liquidity across multiple segments of the credit markets." ROGER MERRITT \& EILEEN FAHEY,

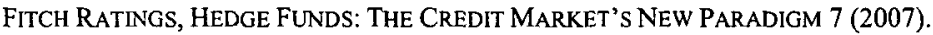

196. Taking account of capital market volatility is another reflection of the way the banking business has changed from a lend-and-hold business to an originate-and-distribute business:

The market turmoil that began in mid-2007 has highlighted the crucial importance of market liquidity to the banking sector .... These events emphasised [sic] the links between funding and market liquidity risk, the interrelationship of funding liquidity risk and credit risk, and the fact that liquidity is a key determinant of the soundness of the banking sector.

BASEL COMM., supra note 56, at 1. Established by G-10 countries in 1975, the Basel Committee on Banking Supervision formed the Working Group on Liquidity in 2006 to "take stock of liquidity supervision" in its current member countries-Belgium, Canada, France, Germany, Italy, Japan, Luxembourg, the Netherlands, Spain, Sweden, Switzerland, the United Kingdom, and the United States. Id.

197. Formerly, banks borrowed at shorter terms and lent at longer ones, making longer term credit available to credit consumers and, in so doing, bearing funding liquidity risk from mismatches in their payables and receivables. Indeed, this was part of the function of banking: "The fundamental role of banks in facilitating the maturity transformation of short-term deposits into long-term loans makes banks inherently vulnerable to liquidity risk, the risk that demands for repayment outstrip the capacity to raise new liabilities or liquify assets." BASEL COMM., supra note 56, at 2. This is less true of commercial banks insofar as they originate to distribute and more true of other financial firms that have begun to originate and trade credit.

198. Katrina Booker, The Day $\$ 2$ Billion Walked Out the Door, FORTUNE, Apr. 14, 2008, at 98, 99-100.

199. Id.

200. Shawn Tully, What's Wrong with Wall Street and How to Fix It, FORTUNE, Apr. 14, 2008, at 70, 72 74.

201. See Sloan, supra note 114 , at 82 ; supra note 114 and accompanying text. 
"specialness" that way. And, apart from their direct role as lenders to other borrowers, these nonbank firms provide price support in the secondary market which-as Minsky's implications about leveraged liquidity suggest - bears indirectly but importantly on firm liquidity. Moreover, nonbank lenders make it harder to track the credit supply and to understand the links between the financial economy and the real economy, as suggested by the former chairman of the U.K.'s Financial Services Authority. ${ }^{202}$

At a recent monetary research conference, Fed Chairman Bernanke encouraged academics to study nonbank lenders in the credit market. ${ }^{203}$ His comments echo Minsky's focus on the role played by the liability structures of financial intermediaries in increasing financial instability. ${ }^{204}$ So regulators are now trying to combat what the Chairman of the SEC recently called the "statutory supervisory gap" caused by treating the liquidity problems of investment banks differently from those of commercial banks. ${ }^{205}$ One attempt to move beyond the banking model is the statement of the President's Working Group on Financial Markets about the role of "private capital pools." 206 The open-ended category_-"private capital pools"--sounded a new, though tardy, note by nodding to a variety of intermediaries whose financial impact on other firms was unknown but suspected of being material. ${ }^{207}$ More institutionally nuanced than the "capital pool" idea (and directly in line with Minsky's emphasis on financial firms) is the concept of "leveraged financial intermediaries" used by Adrian and Shin to describe both commercial and investment banks. ${ }^{208}$ Moreover, if Adrian and Shin's conclusion

202. This is what is meant by the "shadow" banking system:

A very large amount of credit was being created outside the banking system. All of the central banks and the other authorities probably did underestimate that and the market itself has been surprised to discover how much these instruments were being used to generate credit outside the banking system. Credit conditions were much looser than the authorities had believed.

Sean O'Grady et al., Credit Crunch One Year On, INDEPENDENT, Aug. 5, 2008, at 38 (quoting Sir Howard Davies in a group interview on the anniversary of the credit crunch with financial cognoscenti).

203. Ben S. Bernanke, Chairman, Fed. Reserve, The Financial Accelerator and the Credit Channel: Address at the Credit Channel of Monetary Policy in the Twenty-First Century Conference (June 15, 2007).

204. Bernanke noted that "[ $n]$ onbank lenders may well be subject to the same forces" to which banks are in the credit channel. Id.

205. See Cox Testimony, supra note 43 (discussing recent events in the financial markets and the implications of the merger agreement between JP Morgan and Bear).

206. President's Working Group on Fin. Mkts., Agreement among PWG and U.S. Agency PRINCIPAls on PRINCIPLes aNd Guidelines REgarding PrIVATE PoOls of CaPITAL (2007) [hereinafter PRINCIPLES \& GUIDELINES]; see also Press Release, U.S. Dep't of the Treasury, Common Approach to Private Pools of Capital Guidance on Hedge Fund Issues Focuses on Systemic Risk, Investor Protection (Feb. 22, 2007), available at http://www.ustreas.gov/press/releases/hp272.htm. The Working Group is an interagency body with representatives of the U.S. Treasury, the Board of Governors of the Federal Reserve, the U.S. SEC, and the U.S. Commodity Futures Trading Commission, charged with examining financial market trends with regulatory and risk implications that cut across the narrower interests of each particular government agency.

207. The warning is odd because it raises basic principles of counterparty risk management with professional investors who are already in the best position to grasp the risks of the new credit market. PRINCIPLES \& GUIDELINES, supra note 206, at 3-5. Recommendations 7 and 8 address the due diligence of, respectively, creditors and investors in these pools of capital. Id.

208. See ADRIAN \& SHIN, supra note 14, at 3; see also, e.g., Christian Ewerhart \& Natacha Valla, Financial Market Liquidity and the Lender of Last Resort, FIN. STABILITY REV., Feb. 2008, at 133, 138-40 (examining how these entities tend to liquidate their securities portfolios quickly in response to unanticipated downturns, thereby intensifying downward price cycles). 
that investment banks engage in more procyclical leveraging than do commercial banks is right (a point taken up in the next section), then other nonbank lenders may do the same, thereby facilitating more speculative and Ponzi financing.

Of the nonbank firms, sovereign wealth funds may raise special questions about their role in engendering fragility in the financial sector because they operate behind the cloak of sovereignty. These funds are semi-private capital pools funded by countries with budget surpluses, earned from exports of oil and other commodities. ${ }^{209}$ These funds use foreign reserves in two general ways: as "stabilization" funds and as "savings funds." 210 Stabilization funds promote financial stability in the sponsoring country, essentially by putting revenues from major exports into a cookie jar to manage budget shortfalls. Savings funds serve the "inter-generational" goal of pooling current commodity export revenues (that are not only volatile but may be finite) for the benefit of future citizens. ${ }^{211}$ While laudable goals, they may impact the economic stability of other countries. ${ }^{212}$ The United States and other governments have begun to insist on surveillance of these funds. ${ }^{213}$

These funds added "mobile capital" that intensified the leverage wave by creating investment demand for financial assets. ${ }^{214}$ Because their goal is to support a government's various financing needs, "[ $t]$ he claims on sovereign wealth portfolios will typically be more equity-like." 215 If so, these funds might prefer riskier investment, which promises a higher return to the lender, including speculative and Ponzi lending. In effect, these funds are the sovereign version of the off-balance sheet (OBS) items that

209. State St. Global advisors, Who Holds the Wealth of Nations? 1 (2005), available at http://www.ssga.com/library/esps/Who_Holds_Wealth_of_Nations_Andrew_Rozanov_8.15.05REVCCRI1 1459 95576.pdf. For example, here I have extracted only the oil-based sovereign wealth funds (these are the largest types) with a reported value of more than $\$ 1$ billion: Abu Dhabi Investment Authority (United Arab Emirates) $\$ 250$ billion; Government Petroleum Fund (Norway) $\$ 170$ billion; Kuwait Investment Authority (Kuwait) $\$ 65$ billion; Brunei Investment Authority (Brunei) $\$ 30$ billion; Alaska Permanent Reserve Fund (U.S.) $\$ 30$ billion; Oil Stabilisation Fund (Russia) \$28 billion; Alberta Heritage (Canada) \$10 billion; Foreign Exchange Reserve Fund (Iran) \$8 billion; Kazakhstan National Fund (Kazakhstan) \$5 billion; Oman State General Reserve Fund (Oman) $\$ 2$ billion; and Azerbaijan State Oil Fund (Azerbaijan) $\$ 1$ billion. Id. at 2. This list does not include Saudi Arabia's sovereign wealth fund, although it is estimated to be as large as that of the United Arab Emirates. See Morgan STANLEy, How Big Could SOVEREIGN Wealth Funds BE BY 2015? 2 (2007), available at http://www.morganstanley.com/views/perspectives/files/soverign_2.pdf (estimating Saudi Arabia's sovereign wealth fund at $\$ 300$ billion). The IMF's Financial Stability Report mentions these funds too. IMF, 2007 FINANCIAL STABILITY REPORT, supra note 29, at 74.

210. Fred Weinberger \& Bennett Golub, Asset Allocation and Risk Management for Sovereign Wealth Funds, in SOVEREIGN Wealth MANAGEMENT 74 (Jennifer Johnson-Calari \& Malan Rietveld eds., 2007) [hereinafter SOVEREIGN WEALTH].

211. Id. at 74-75.

212. As one journalist noted: "[E]xperts are asking whether cross-border investment is evolving into something new that could be called cross-border nationalization, raising the specter of government interference in free markets - only this time, in other countries' markets rather than their own." Steven R. Weisman, "Sovereign Funds" Stir Growing Unease, INT'L Herald TRIB. (Paris), Aug. 21, 2007, at 1 (noting the U.S. Treasury's request to the IMF to increase financial surveillance of country-funded investment pools).

213. Id.

214. New York Fed President Geithner mentioned these funds as one factor which had changed the structure of financial markets: "The increase in size of sovereign wealth funds, the shift in assets to hedge fund and private equity managers, and the possible reduction in home bias among private savers have increased the amount of mobile capital in search of higher returns." See Geithner, supra note 123.

215. See Weinberger \& Golub, supra note 210 , at 73 . 
came into focus in the domestic context after the collapse of Enron. ${ }^{216}$ In private firms, OBS arrangements let a firm avoid the brunt of legal prohibitions keyed to the firm's balance sheet figures. ${ }^{217}$ In this sense, the liquidity in sovereign capital pools gives government officials "switching options" with respect to investment. 218 Indeed, recession might drive many of these switching options into the money as market liquidity for assets dries up, creating investment bargains. ${ }^{219}$ The key question is how they did and will invest. $^{220}$

For example, sovereign wealth funds have increased their aggregate investment in Western financial firms from less than $\$ 500$ million in the first quarter of 2007 to over $\$ 10$ billion since the following quarter. ${ }^{221}$ As a Financial Times editorial put it, the equity bailout of U.S. financial institutions by one of these funds suggests the "virulence

216. José Gabilondo, Financial Moral Panic! Sarbanes-Oxley, Financier Folk Devils, and Off-BalanceSheet Arrangements, 36 SETON HALL L. REV. 781, 810-19 (2006).

217. See Samir El-Gazzar et al., The Use of Off-Balance Sheet Financing to Circumvent Financial Covenant Restrictions, 4 J. ACC. AUDITING \& FIN. 217 (1989) (analyzing 43 addenda to leases which contained debt covenants to examine how firms use OBS arrangements to modify covenant-based restrictions); $c f$. In re Explorer Pipeline Co., 781 A.2d 705, 712 (Del. Ch. 2001) (holding that a corporation's decision to enter into an OBS operating lease was not subject to a supermajority provision found in the corporation's certificate of incorporation).

218. George Triantis, Financial Slack Policy and the Laws of Secured Transactions, 29 J. LEGAL STUD. 35, 39 (2005) ("As a general proposition, managers are much more prone to take actions that increase their welfare (for example, perquisite consumption or empire building) or the welfare of their shareholders (for example, share repurchases or high-risk investments) if they have cash at their disposal.").

219. Some funds have already started exercising these in-the-money options:

UBS joins a growing list of Western banks, including Bear Stearns Cos., Barclays PLC, and HSBC Holdings PLC, that have received [governmental] capital injections from Asia and the Middle East this year. The sovereign funds "are really smart and are getting to see a huge number of opportunities around the globe at this moment," says Guy Cornelius, a managing director in Lehman Brothers Holding Inc.'s fixed income department.

Carrick Mollenkamp et al., UBS's Subprime Hit Deepens Credit Worries, WORLD FIN. REPORT, Dec. 11, 2007, available at http://worldfinancial.blogspot.com/2007/12/ubss-subprime-hit-deepens-credit.html; see George Magnus, Market Insight: Tough Tactics to End Credit Crisis, FIN. TIMES, Nov. 28, 2007, at A23 (calling the $\$ 7.5$ billion equity investment of a sovereign wealth fund in a U.S. bank as "yet another strong indicator of the virulence of the Minsky Moment-a credit crisis named after economist Hyman Minsky who analyzed the causes of financial instability").

220. See, e.g., Jennifer Johnson-Calari, Managing Commodity Revenues and Windfall Profits: Investment Income Funds, in SOVEREIGN WEALTH, supra note 210, at 47, 47 (discussing alternative asset allocation and spending policies for sovereign wealth funds designed to produce perpetual income); Bernard Lee, Robust Portfolio Construction in a Sovereign Wealth Context, in SOVEREIGN WEALTH, supra note 210, at 157, 157 (analyzing the "tactical allocation of professional money managers within the chosen strategy bucket, after the appropriate combination of broad asset strategies for the sovereign wealth fund has been determined").

221. See Mollenkamp et al., supra note 219; Henny Sender, Abu Dhabi Considers Apollo Stake, WaLl ST. J., July 6, 2007, at $\mathrm{Cl}$ (discussing the proposed investment of the Abu Dhabi sovereign fund in a private equity fund). Last year a sovereign subsidiary of the Abu Dhabi Investment Authority established a small fund of hedge funds, the Multi-Strategy Hedge Fund. Press Release, Abu Dhabi Inv. Co., ADIC Launches the First Multi-Strategy Hedge Fund in the Region, available at http://www.adic.ae/PDFs/newsbank/PressRelease ADIC_Multi_Strategy_Hedge_Fund_English.pdf (anticipating initial funding of $\$ 60$ million). The Abu Dhabi Investment Authority owns a majority interest $(97 \%$ as of December 2006$)$ in the Abu Dhabi Investment Company. ERnST \& Young, CONSOLIDATED FinanCIAL STATEMENTS: ABU DHABI INVESTMENT COMPANY 17 n.11 (2006). The same subsidiary also syndicates loans, deals in foreign exchange and the money market, provides trade financing, and offers securities, commodities, and other investment services. Id. at 6 . 
of the Minsky Moment."222

\section{Secondary Credit Markets}

The final factor contributing to the current liquidity dynamics is the secondary credit markets themselves. ${ }^{223}$ Minsky recognized that secondary markets promote funding liquidity for firms, because they let firms sell an asset for cash, although he noted that only a central bank could avoid "epidemics of confidence or lack of confidence," by lending against the confidence cycle. 224 The Fed interventions described earlier, such as the Bear deal and the new collateral rules, are an example of such stabilizing secondary market lending. Whether private secondary markets add or reduce stability is less clear. Granted, the secondary market for credit products is much less active than that of equity securities, although it has grown since electronic trading platforms for debt emerged in the $1990 \mathrm{~s}^{225}$ Even before these trading platforms arose, though, versions of a secondary market for corporate loans existed, because banks would sell loans to correspondent banks and bankruptcy trustees also sold loans. ${ }^{226}$ Two things had to happen before the secondary markets for syndicated loans would take off. ${ }^{227}$ First, in the 1990s banks decided to divest themselves of risky corporate loans in response to pressure from their regulators and shareholders. ${ }^{228}$ Second, the originate-to-distribute model spread from

222. See Magnus, supra note 219 (stating Magnus's view of the $\$ 7.5$ billion equity investment of a sovereign wealth fund in a U.S. bank as "yet another strong indicator of the virulence of the Minsky Momenta credit crisis named after economist Hyman Minsky who analyzed the causes of financial instability").

223. One sees the trend toward both nonbank lenders and secondary markets in the history of the money market, which includes credit obligations of less than one year. When analyzing money market rates trends between 1900 and 1945, Homer and Sylla's $A$ History of Interest Rates uses prime commercial paper, call loan rates, short-term Treasury rates, short prime corporate bonds, banker's acceptances, and, after the establishment of the Federal Reserve System, a discount window rate. HISTORY OF INTEREST, supra note 36, at 356-63. In order to convey the same information for the period after 1946, federal funds, short-term Eurodollars (to reflect the growth of concentration in overseas concentrations of dollars), and, importantly, the secondary market rates for negotiable certificates of deposit are added. Id. at 387.

224. For secondary markets to be an effective determinant of system stability, they must transform an asset into a reliable source of cash for a unit whenever needed. MINSKY, CAN IT?, supra note 24, at 149.

225. The median stock trades every few minutes while the median bond trades once every three months. George Chacko, Liquidity Risk in the Corporate Bond Markets 8 (Jan. 15, 2005) (unpublished manuscript), available at http://ssm.com/abstract=687619 (analyzing liquidity trends in bond market). Each year, the Securities Industry Financial Markets Association surveys the status of these trading platforms. SEC. INDUS. \&

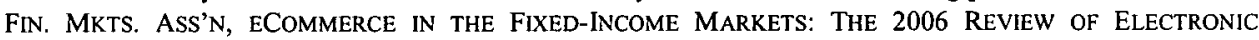
TRANSACTION SYSTEMS 1-3 (2006). No single platform covers all the following asset classes, but, in the aggregate, these trading platforms feature asset-backed securities, commercial paper, credit derivatives, certificates of deposit, Euro bonds, foreign exchange forwards, futures, options, interest rate swaps, repurchase agreements, over-the-counter derivatives, agency and private mortgage-backed securities, structured notes, sovereign debt, whole loans, exchange-traded funds, and more. Id. at 17. See generally Noah L. Wynkoop, Note, The Unregulables? The Perilous Confluence of Hedge Funds and Credit Derivatives, 76 FordHAM L. REV. 3095, 3112-13 (2008) (analyzing the market structure of the corporate bond market).

226. Hugh Thomas \& Zhiqiang Wang, The Integration of Bank Syndicated Loan and Junk Bond Markets, 28 J. BANKING \& FIN. 299, 300 (2004).

227. For example, the dollar volume of secondary trading of these syndicated loans increased more than thirteen-fold between 1991 and 2001 . Id. at 302 (showing increase in secondary market trading volume from \$8 billion in 1991 to $\$ 110$ billion in 2001).

228. Lumpkin, supra note 47 , at 58 . 
residential mortgage lending to corporate credit. ${ }^{229}$

Price outcomes in the secondary market "relate back" to primary underwriting, ${ }^{230}$ for example, by influencing the spread that the borrower must pay on new loans. ${ }^{231}$ These markets also matter to borrowers because liquifying assets gives lenders more cash for fresh loans and gives them an "out," should they no longer want to hold the borrower's credit. ${ }^{232}$ But if no buyer wants the loan, it gets stranded on the lender's balance sheet, as banks discovered beginning in the summer of $2007 .{ }^{233}$ These secondary markets also tell both traders and regulators about the market perception of a firm's credit quality. Regulators warn banks to monitor how their debt securities trade in the secondary market, because if the bank's debt begins to change hands at a steeply discounted rate, this suggests that the bank is losing the confidence of investors. ${ }^{234}$ For this reason, regulators have considered using secondary market assessments of subordinated debt issued by a bank to monitor trends in the banks solvency and liquidity. 235

An excellent recent discussion of the issue in the context of European banks active in leveraged buyout financing introduced the distinction between "capital turnover" and "portfolio" banks. ${ }^{236}$ Capital turnover banks pursue fee income and tend to quickly distribute any exposure to merger deals in the secondary markets. ${ }^{237}$ Portfolio banks pursue both fees and interest income anticipated from holding debt positions in leveraged

229. The shift to fee-based revenues coincided with consolidation in the banking sector too. Consolidation produced:

[L]arge entities more oriented toward fee-driven business than to straight portfolio lending. As these institutions have moved from originating loans to be held in their portfolios to originating loans and then collecting fees for structuring, distributing and servicing loan assets, the secondary market for commercial loans has grown and taken on many of the same characteristics of the corporate bond market.

Id. at 62 .

230. The cost to a borrower of issuing new loans is:

$[\mathrm{N}]$ ow determined not only by rating and leverage profile, but also by trading levels relative to par of an issuer's previous loans, and market sentiment tied to demand and supply ... the effect has been to increase market volatility with regard to trading and to make the pricing of primary market syndicated loans far more dynamic than in the past.

Id. at 70 .

231. Id. at 66 .

232. Indeed, "[w]hen considering various financing options, prospective issuers will receive information from their agent bank/or investment bank regarding the pricing of their existing liabilities in the loan, bond and derivatives markets." $I d$. at 72 .

233. Though referring to banks, this was the case for other financial firms too: "[S]ome firms had relied on securitisation . . . as a way to reduce assets on the balance sheet under normal market conditions, but during times of stress were forced to postpone some securitisations, leading to a build up of warehoused assets." See BASEL COMM., supra note 56, at 3.

234. LIQUIDITY HANDBOOK, supra note 41 , at 7 (listing "bearish secondary market activity" as one type of early warning sign of a bank's liquidity risk).

235. Secondary market prices for this subordinated debt, it is thought, will reflect an open market assessment of what federal bank examiners would otherwise discover by reviewing the issuing bank's financial condition. See Gramm-Leach-Bliley Financial Services Modernization Act, Pub. L. No. 106-102, § 108, 113 Stat. 1338 (1999) (mandating study on the use of subordinated debt as a tool of banking supervision).

236. See EUROPEAN CENT. BANK, supra note 165 , at 19-20 (introducing the distinction in part of a larger discussion of bank survey results).

237. Id. 
buyouts in which they have provided financing. ${ }^{238}$ Apart from deriving income differently, capital turnover and portfolio banks offer different kinds of debt instruments in their merger financing. ${ }^{239}$ The standardizing discipline of cash flow discounting would suggest that both the lend-to-maturity model of a portfolio lender and the originate-to-distribute model of a capital turnover bank would result in the same value for a loan, whether or not it is held to maturity or held out for sale. In fact, though, this may not be the case.

Credit derivatives (one kind of secondary market product) have both helped and hurt in terms of providing market liquidity. Credit derivatives let a lender reduce its exposure to the borrower's default by supplementing or substituting the cash flow from the borrower with a promise from another firm to make the lender whole for credit losses. ${ }^{240}$ Credit derivatives create (and are intended to create) risk-shifting channels between different types of intermediaries, for example banks and insurance companies. ${ }^{241}$ It was thought that these derivatives would spread credit risk beyond banks and into other deep pockets to bear credit losses. When these deep pockets were asked to perform, however, some of the credit insurers had liquidity (and solvency) problems of their own. During the current credit crunch, the cost of credit insurance for investment-grade debt became volatile, even intra-day. ${ }^{242}$ And risk channels can spread contagion between markets, as suggested when a downgrade of one tranche of collateralized debt obligations triggered concern about structured credit products generally. ${ }^{243}$ Moreover, an investor may increase its exposure to a loss if the investor owns related products that derive from that loss. ${ }^{244}$ These are all examples of risk diversification not living up to what risk

238. Id.

239. Id. at $27-29$.

240. See Partnoy \& Skeel, supra note 15, at 1022-31 (explaining the benefits of credit derivatives).

241. Although its forms differ, in a credit derivative contract, the "protection seller" promises the "protection buyer" to transfer a cash flow to the buyer if the buyer suffers a credit loss on a transaction with a counterparty:

The recent growth of risk transfer across sectoral boundaries leads to increased inter-linkages among the sectors. Credit derivatives are an example. Because of the nature of their core business, banks tend to operate as net protection buyers. Insurers, on the other hand, tend to be protection sellers, whereas securities firms take positions from a trading perspective.

BASEL COMM., supra note 56, at 25.

242. See Mark Whitehouse et al., The Sky Darkens for Bondholders-Backfiring Bets on Derivatives, Corporate Executives' Allegiances Are Among Worries Raising Risk, WALL ST. J., May 12, 2005, at Cl (noting that after an S\&P downgrade of some major industrials, the "average annual cost of buying protection on $\$ 10$ million in investment-grade corporate debt rose to $\$ 76,000$ from $\$ 71,500$ " before settling "nearly unchanged" by the market close).

243. See Henny Sender et al., Risky Strategies Take Toll on Traders-Derivative Products Suffer Amid Increasing Concerns Surrounding Corporate Debt, WALL ST. J., May 11, 2005, at C6 (noting that the effects in secondary and derivative credit markets of S\&P downgrades of the underlying debt of several major U.S. industrials revealed the scope and sensitivity of cross-market links).

244. Chairman Bernanke identifies this as a risk of complex financial activity: "What is essentially the same risk can appear in different forms; for example, investments in a CDO tranche, a bond, and a credit default swap may all entail credit risk to a given obligor." Ben S. Bernanke, Regulation and Financial Innovation: Speech to the Federal Reserve Bank of Atlanta's 2007 Financial Markets Conference (May 15, 2007), available at http://www.federalreserve.gov/boarddocs/speeches/2007/20070515/default.htm. 
management models predicted. ${ }^{245}$

\section{The Revival of Financial Cycle Theory}

By now a consensus has formed among academics and financial regulators that the credit contraction was the bust stage of a financial cycle that had previously included a boom. The President of the Federal Reserve bank that made the Bear loan admitted as much in recent testimony: "The intensity of the crisis we now face in U.S. and global financial markets is a function of the size and character of the financial boom that preceded it." 246 This conclusion may seem obvious now, but whether we were in a cycle or had reached a new financial equilibrium was a bone of contention during the run-up in asset prices.

For example, those who conceded that borrowing cycles could contribute to financial instability might have been justified-at least until summer 2007-in feeling that regulation had already "corrected" the cycle. ${ }^{247}$ After all, it had been years since a major crash, so it would seem to have been plausible to think that we had transcended financial instability. 248 Another reason against cycle arguments is that they need comparable information about borrowing in different periods that is just not available, as noted about high-yield issuance, ${ }^{249}$ corporate debt, 250 and interest-rate history in general. ${ }^{251}$ More vigorous objections to cycle arguments came from growth boosters and financial promoters. For example, as Fed Chairman, Alan Greenspan reassured growth skeptics that a new plateau of efficiency was behind the then prosperity (leveraged, as it

245. See Fisher, supra note 106, at 29 (explaining how risk dispersion models failed to account for misunderstood risks and intra-firm risk movements).

246. Geithner Statement, supra note 9.

247. "As the sixties progressed, eminent economists-especially those associated with government policy formulation-who in their own minds were disciples of Keynes, were announcing that endogenous business cycles and domestic financial crises were a thing of the past, now that the secrets of economic policy had been unlocked." MINSKY, KEYNES, supra note 124, at 15.

248. Minsky noted:

Thus an economic theory based upon a business cycle associated with a financial-instability view of how the economy operates can be replaced by theory with an equilibrium and steady-growth perspective, because the relevant observations to substantiate the cyclical, financial-instability view cannot be made. This is what took place as the forties, fifties, and sixties spun their tales of war and apparent economic success-a success achieved with the aid of apparently appropriate monetary and fiscal policy.

Id. at 16 .

249. As noted about these markets, "A serious problem exists even with what should be simple measures of volume and value-not all published measures are the same. The 'size of the market' can alternatively mean 'all outstanding' or 'outstanding less defaults,' leading to indeterminacy." YAGo \& TRIMBATH, BEYOND JUNK BONDS, supra note 137 , at vii-viii.

250. Acknowledging the lack of a central database for bond transactions, one group of researchers used the database of a securities custodian to examine bond trading. See Chacko, supra note 225, at 3 (arguing that broker or market maker accessibility to a security is a proxy for a bond's trading market liquidity).

251. At best, one gets an impressionistic sense of certain lending trends: "Economists sometimes ask the impossible: a series of yields or interest rates over long periods of time derived from instruments of substantially identical terms ... The objectives of some forms of economic analysis require just this uniformity. In real life it often does not exist, even from year to year." HISTORY OF INTEREST, supra note 36, at 433-34. 
is turning out to have been). ${ }^{252}$ In chorus, the IMF reported in 2006 that the high levels of corporate borrowing before the credit crunch reflected "capital structure arbitrage" in which under-leveraged firms took healthy advantage of investor appetite for risk. ${ }^{253} \mathrm{By}$ the following year, the IMF found itself more open to cyclicality: in 2007, it objected to the "credit indiscipline" of these same borrowers and lenders. ${ }^{254}$

For the time being, at least, the consensus is, again, that financial cycles do exist. This section explains that the trend toward fragility in the financial sector (through borrowing) discussed above is not a one-time movement but, instead, part of an ongoing cyclical process that is routine in financial capitalist economies like ours. Financial loss makes a market for reflection, so the reality of cyclical instability may get a better hearing now. As in the previous discussion, financial intermediaries figure prominently in these cycles.

The Great Crash made a market for theories that could explain the economy as a whole or, at least, in terms of aggregates. ${ }^{255}$ For example, the National Income and Product Accounts developed during this time to model national output; they are still used for balance-of-payments reporting. ${ }^{256}$ Early mapping of the financial system also began

252. Dean Foust, Alan Greenspan's Brave New World, BUS. WK., Jul. 14, 1997, at 44 (analyzing how Alan Greenspan's assumptions about the possibility of continuing growth influenced the Federal Open Market Committee's decision not to raise interest rates). The Federal Open Market Committee minutes for that meeting reflect the Committee's assumption about ongoing growth. Minutes of the Federal Open Market Committee Meeting Held on May 20, 1997, FED. RES. BULL., Sept. 1997. The minutes noted:

[P]rospects for subsequent quarters were subject to substantial uncertainty, but the members generally felt that the economy retained considerable underlying strength. In the circumstances and assuming no changes from current financial conditions, the individual members saw likely prospects for expansion over the forecast horizon at a pace close to, or a little above, the estimated growth of the economy's long-run potential.

ANNUAL REPORT, BOARD OF GOVERNORS OF THE FEDERAL RESERVE 127 (1997).

253. The IMF distinguished these transactions from those of the 1980 s because this time investors also committed equity capital: "[M] any of these leveraged restructurings also involve a higher degree of proprietary exposure on the part of acquirers - not only do they mobilize other investors' credit resources but they are also taking equity stakes in the acquired firms-than did the leveraged restructurings of the 1980s." IMF, 2006 FINANCIAL STABILITY REPORT, supra note 76, at 29.

254. IMF, 2007 FINANCIAL STABILITY REPORT, supra note 29, at 2.

These risks have been exacerbated by signs of similar credit indiscipline in the leveraged buyout (LBO) sector. Through mid-2007, there had been a marked rise in covenant-lite loans, less creditworthy deals, leverage, and price multiples on acquisitions .... Although aggregate corporate leverage remains relatively low, its increase over the past year, particularly for those entities that have been the subject of buyouts, has heightened vulnerabilities, especially as financial, and possibly economic, conditions turn less benign.

Id.

255. Pouncy, supra note 22, at 568-69. This affected both the domestic and global economy. The standard industrial classification which divides industries (financial industries are in the four digit series beginning with " 6 ") began as an outgrowth of the Department of Labor. The National Income and Product Accounts (NIPA), which would be used to track global balance of payments, also began in the 1930s. The NIPA accounts were the precursors to what would become the Flow of Funds system.

256. Carol S. Carson, The History of the United States National Income and Product Accounts: The Development of an Analytical Tool, 21 REV. INCOME \& WEALTH 153, 153 (1975).

The generally recognized need for economic information during the Great Depression stimulated the request that the Department of Commerce undertake what became the first official continuing 
in this period with a study of national money flows from 1952 that would lead to the Fed's flow of funds accounts; the equivalent of a national credit balance sheet and cash flow statement detailing who borrows, who lends, and how, flow of funds data is still the richest data set on credit. ${ }^{257}$ In this milieu, economist Arthur Burns and his student Geoffrey Moore developed business cycle theory. ${ }^{258}$ Business cycle theory emphasized that the economy as a whole included long-term patterns of relative growth or contraction punctuated by shorter-lived specific phases during which the economy could expand, peak, contract, hit a trough, or recover. ${ }^{259}$ The U.S. economy has since faced no crashes of the size of the Depression, but cycle theory still informs how we determine whether or not we are in an economic recession. For example, in December 2008 the National Bureau of Economic Research determined that the U.S. economy had entered a recession beginning the previous December, the point at which the business cycle had reached its peak. ${ }^{260}$

Business cycle theory looks at the economy as a whole, but it applies to borrowing as well. Beginning in 1946, W. Braddock Hickman carried out the first major study of corporate borrowing cycles as part of the Corporate Bond Project, a Work Projects Administration effort of the FDIC and the National Bureau of Economic Research. ${ }^{261}$ Hickman wondered whether corporate borrowing followed the same pattern as the business cycle, so he plotted bond issuance by firms against business cycle indicators. ${ }^{262}$ Rather than following the bust and boom of the business cycle, net bond issuance, it turned out, increased at the bottom of the trough (when the real economy was contracting) and decreased at the peak (as the real economy was expanding). ${ }^{263}$ Perhaps retained earnings let firms fund growth at the top of the peak and firms borrowed more when earnings were lean. Or the reluctance to borrow may have reflected the memory of the Great Crash or a more general conservative impulse to protect the firm's gain from

series on national income in the United States. These estimates were prepared with the cooperation of the National Bureau of Economic Research and were published in 1934.

Id.

257. The seminal study on this question was one published by Morris Copeland in 1952. MORRIS A. COPELAND, A STUDY OF MONEYFLOWS IN THE UNITED STATES (1952).

258. The business cycle was the insight that some economic indicators moved in tandem. During a period of economic expansion, output rose along with new construction, employment rates, and many prices; conversely, during an economic downturn-a recession-output, employment, and new construction declined while unemployment increased. Werner H. Strigel, Business Cycle Surveys: A New Quality in Economic Statistics, in ANALYZING MODERN Business CYCles-EsSAYS HONORING GeOFFreY H. MOORE 69, 72 (Philip A. Klein ed., 1990).

259. Id.

260. Nat'l Bureau of Econ. Research, Determination of THe December 2007 PEaK IN ECONOMiC ACTIVITY (2008), available at http://www.nber.org/cycles/dec2008.pdf.

261. Between 1953 and 1960 , this project produced three volumes. The first volume was The Volume of Corporate Bond Financing Since 1900 (1953). The second, Corporate Bond Quality and Investor Experience (1958), considered different measures of bond quality. The final volume, Statistical Measures of Corporate Bond Financing Since 1900 (1960), presented the statistical data on which the previous volume was based. Other studies looked at trade credit. See generally MARTIN H. SEIDEN, THE QuALITY OF TRADE CREDIT (1964) (examining trade credit). The study formed part of the National Bureau of Economic Research's Quality of Credit Program. Id. at xix.

262. Hickman, supra note 136 , at $20-25$.

263. Id. at 21 . 
risk. ${ }^{264}$ Hickman offered no specific explanation, but he concluded that bond issuance was counter-cyclical and could, therefore, have a stabilizing effect on the business cycle. ${ }^{265}$

Minsky reached the opposite conclusion in his financial instability thesis. When the economy was strong and interest rates were low, Minsky said, firms would borrow themselves (and the economy as a whole) into periods of acute financial fragility, hence the economy's "tendency to explode." 266 This tendency to explode resulted from structural biases in capitalist economies towards increasingly riskier forms of financing by firms. ${ }^{267}$ The thesis was an early form of behavioral finance because it explained macroeconomic trends--like financial cycles-in terms of the peculiarities of human decisionmaking. ${ }^{268}$ A child of the Depression, Minsky recognized that self-policing markets could productively coordinate many of the details of economic life, but he saw the need for regulatory intervention too. ${ }^{269}$ So, he thought that economic analysis should set out the "institutional prerequisites for successful capitalism." 270 One of those

264. Pouncy notes that risk is itself perceived differently in different risk environments, such that a firm may be more conservative to protect gains but more willing to take on risks -in this case by borrowing - to reverse a pattern of losses. See Pouncy, supra note 22, at 563-64.

265. Part of what was new about the insight was that it suggested that particular kinds of credit might have their own dynamics:

These findings throw new light upon the familiar theory that "credit," in a generic sense, plays a dominant role in the business cycle. Clearly a distinction needs to be drawn between the various forms of credit. Many types of financing-for example short-term and stock financing--appear to behave in the way theory would indicate; but bond financing runs a contrary course to other types and thus acts, so to speak as a stabilizing force.

Hickman, supra note 136, at 21.

266. MINSKY, CAN IT?, supra note 24 , at 118.

267. For a discussion of hedge, speculative, and Ponzi financing, see supra notes 140-66 and accompanying text.

268. McCulley put the gist of the theory nicely at a recent conference on the credit market dedicated to Minsky's work:

[S]tability is destabilizing, because market participants, or economic agents, being human beings, extrapolate stability into infinity. And, if you extrapolate stability into infinity, then you inherently take on ever more risky debt structures. ... [T] he world is not inherently mean-reverting on the basis of value. The world is inherently momentum-driven .... Intellectually, we know to buy low and sell high, but emotionally, we can't bring ourselves to do that; we tend to do the exact opposite, which imparts an intense procyclical character to capitalism. Perhaps even worse, it imparts procyclicality to regulatory structures. Not only are the kids and the frat party procyclical, but the guidance counselor is too. That's a reality of financial markets.

McCulley, supra note 155 , at 9.

269. MINSKY, UNSTABLE ECONOMY, supra note 130 , at 5 . His is a good synthesis for those who respect financial markets while wanting to improve them:

For a new era of serious reform to enjoy more than transitory success it should be based on the understanding of why a decentralized market mechanism - the free market of the conservatives - is an efficient way of handing the many details of economic life, and how the financial institutions of capitalism, especially in the context of production processes that use capital-intensive techniques, are inherently disruptive.

Id.

270. Hyman P. Minsky, Uncertainty and the Institutional Structure of Capitalist Economies, $30 \mathrm{~J}$. ECON. ISSUES 357, 357 (1996) ("The current crisis of performance and confidence in the rich capitalist countries makes 
"prerequisites" was stabilizing the economy and, in particular, the financial sector. ${ }^{271}$

I have looked at an increasingly prominent line of research on financial cycles and it is congruent with Minsky's analysis. ${ }^{272}$ Like Minsky, economists Tobias Adrian and Hyun Song Shin suggest that borrowing cycles do exist and that the borrowing cycles follow certain aspects of the business cycle. ${ }^{273}$ That is, leverage is "procyclical" for some types of financial intermediaries, increasing as asset values grow, which they do during a price bubble. ${ }^{274}$ Adrian and Shin compared the leverage ratios of four kinds of economic units to see whether these units borrowed more or less (in proportion to their equity) when their asset value increased, as would be the case on the upside of the business cycle. ${ }^{275}$ The four units were households, nonfinancial firms, commercial banks, and investment bank broker-dealers. ${ }^{276}$ The units displayed different tendencies. The leverage of households declined as asset value increased. 277 (Because the household data runs only from 1963-2006, the finding does not reflect the procyclical leveraging-much of it subprime- -that has destabilized many current households.) No discernible relationship emerged between leverage and asset size for nonfinancial firms. ${ }^{278}$ Clearer patterns emerged for both commercial and investment banks; however, both are examples of firms that borrow to lend whose role in financial instability Minsky emphasized. The leverage ratio of commercial banks tended to remain constant as their balance sheets grew, suggesting that commercial banks "target" their leverage ratio. ${ }^{279}$ This should come as no surprise because federal prudential regulation imposes leverage ratios on commercial banks.

Broker-dealer investment banks (an example of a nonbank lender), however, displayed a "strongly positive relationship between changes in total assets and changes in

it necessary, once again, to think about the institutional prerequisites for successful capitalism.").

271. MINSKY, UNSTABLE ECONOMY, supra note 130, at 5-6. Although committed to social justice, he saw some degree of economic stability as a precondition for all other projects:

Distasteful as inequality and inefficiency may be, there is no scientific law or historical evidence that says that, to survive, an economic order must meet some standard of equity and efficiency (fairness). A capitalist economy cannot be maintained, however, if it oscillates between threats of an imminent collapse of asset values and employment and threats of accelerating inflation and rampant speculation, especially if the threats are sometimes realized.

Id.

272. Some of this work comes out of the Princeton Economics Department, of which Ben Bernanke was the chair before joining the Federal Reserve. Justin Lahart, Bernanke's Bubble Laboratory-Princeton Proteges of Fed. Chief Study of the Economics of Manias, WALL ST. J., May 16, 2008, at A1. Indeed, some of the economists that Bernanke recruited to Princeton "are building on work done by the late Hyman Minsky, whose once-ignored ideas about investing manias are now in vogue." Id.

273. See ADRIAN \& SHIN, supra note 14, at 2 ("We show that leverage is strongly procyclical for these intermediaries, and that the margin of adjustment on the balance sheet is through repos and reverse repos (and other collateralized borrowings and lendings).").

274. See id. (discussing procyclical leverage).

275. Id. at 6-8.

276. Id.

277. See id. at 5-6 (noting that aggregate data shows that "leverage is inversely related to total assets").

278. See ADRIAN \& SHN, supra note 14 , at 7-8 (noting that " $[t]$ he scatter chart [for nonfinancial firms] shows much less of a negative pattern [than households]").

279. Id. 
leverage." 280 These firms borrowed (increasing leverage) while asset prices rose, so their borrowing funded investment demand that helped to keep prices rising. ${ }^{281}$ In other words, this type of firm borrowed procyclically. By doing this, they managed their balance sheet in ways that amplified bull market prices during a boom and bear market prices during a bust. ${ }^{282}$ They did this in the repo market discussed earlier. ${ }^{283}$ Anecdotal evidence about the growth of leverage at major investment banks suggests as much. Between 2002 and 2007, the debt-to-equity ratio of the five largest U.S. investment bank firms increased from $30: 1$ to $41: 1$, increasing their ability to capture bumper returns but exposing them to funding liquidity risk on the downside. ${ }^{284}$

This procyclical argument is the opposite of what Hickman had observed about bonds and, at the same time, is consistent with Minsky's claim that financial firms have the tendency to borrow themselves into fragility during periods of easy money. This analysis is similar to Minsky's but it offers no explanation for what causes the direction of price trends to change. So it is a model of a "financial cycle" without the causation that Minsky posited. Remember, Minsky said that it was the escalating increases themselves during the bull cycle that led to the bear raids on the way down.

The liquidity implications of Adrian and Shin's procyclical argument support my claims about liquidity dynamics, particularly the second and third liquidity axioms. ${ }^{285}$ Expressed in terms of liquidity dynamics, procyclical leveraging boosts asset prices and promotes market liquidity by creating investment demand, but the extra leverage may compromise the borrower's liquidity. Herd behavior intensifies this trend insofar as it encourages firm managers to take on more financial risk-including through leverageto avoid standing out from the prevailing sentiment of the moment. ${ }^{286}$ This is especially true when financial uncertainty is greatest. ${ }^{287}$ Conversely, these firms sell investment assets and shed leverage as asset prices fall, thereby intensifying the bear phase. ${ }^{288}$ One

280. See id. at 8-9.

281. See id.

282. See id. at 10-11 (stating the existence of a feedback effect between the adjustment of leverage and price changes).

283. ADRIAN \& SHIN, supra note 14 , at $17-18$.

284. See Tully, supra note 200 , at 74 (noting that leverage has magnified earnings but that the credit crunch has severely limited the ability of firms to sell the securities they bought with borrowed money).

285. See supra notes 66-73, 117-19 and accompanying text (noting that trading liquidity for a firm's liability may not be a proxy for credit quality or the borrower's own liquidity and that cuts in borrowing may have ripple effects on other firms' liquidity).

286. See Pouncy, supra note 22, at 564 ('“A] manager's decision will be evaluated based on whether it is consistent with, or departs from, conventional decision-making and popular sentiment, and rewarded asymmetrically in a manner consistent with conventional decision-making." (citation omitted)).

287. As Pouncy puts it, these managers "prefer to accept the risk of being wrong and losing money along with everyone else to what appears to be the greater risk of being wrong and losing money alone." $I d$. at 565 .

288. This is the general hypothesis about certain financial intermediaries put forward by Adrian and Shin: They borrow during the boom phase, driving prices up. Then they de-leverage during the bust phase, intensifying the downside. They then use repurchase agreements to both lever up and down. ADRIAN \& SHIN, supra note 14 , at 9-10. This loop is the case when procyclical firms maintain a constant level of leverage. Id. The feedback effect is even more pronounced if the firm is-as the investment banks were in Adrian and Shin's study-procyclical:

If we hypothesize that greater demand for the asset tends to put upward pressure on its price (a plausible hypothesis, it would seem), then there is the potential for a feedback effect in which 
example of the effects of cyclical de-leveraging on market prices is the earlier example of investment banks that cut back their credit exposure to hedge funds, in so doing destabilizing the price for credit products being marketed by the same investment banks. ${ }^{289}$ In terms of these dynamics, the Bear deal was counter-cyclical in multiple ways (and designed to be so by the Fed): the Fed lent against falling asset prices; Bear took on more debt from the Fed; and JP Morgan expanded its balance sheet by borrowing from the Fed and acquiring Bear. ${ }^{290}$ Bear and JP Morgan became provisionally more liquid, as did the credit market.

\section{CASE STUDY: LEVERAGED LOANS}

Although junk bonds have received substantial attention, junk loans have not. ${ }^{291}$ I chose junk loans for this case study because they illustrate the four trends discussed above that contribute to speculative and Ponzi financing: they are floating-rate loans that are, in large part, originated by nonbank lenders, traded in secondary markets, and used to finance much of the "shareholder-friendly" activity discussed before, including mergers and leveraged dividends. ${ }^{292}$ They also illustrate the second liquidity axiom: that a firm (in this case, the borrower of the leveraged loan) can become less liquid as the market for its liabilities grows and becomes more liquid. After explaining the instrument and its liquidity implications, I recommend some modest steps to increase the transparency of this market.

\section{A. Instrument and Market Structure}

As shown in the discussion below about origination, the growth of leveraged loans is

stronger balance sheets feed greater demand for the asset, which in turn raises the asset's price and lead[s] to stronger balance sheets. The mechanism works exactly in reverse in downturns. If we hypothesize that greater supply of the asset tends to put downward pressure on its price, then there is the potential for a feedback effect in which weaker balance sheets lead to greater sales of the asset, which depresses the asset's price and lead[s] to even weaker balance sheets.

Id. at 11. But see Wynkoop, supra note 225, at 3101 (noting that hedge funds add countercyclical liquidity by buying and selling against market sentiment).

289. See supra notes $106-08$ (providing hedge fund examples).

290. As the Chairman of JP Morgan made clear in testimony to the U.S. Senate Committee: but for the generous nonrecourse financing offered by the Fed, JP Morgan would not have considered doing the deal. Turmoil in U.S. Credit Markets: Examining the Recent Actions of Federal Financial Regulators: Hearing Before the S. Comm. On Banking, Housing, \& Urban Affairs, 110th Cong. (2008) (statement of Jaime Dimon, Chairman, JP Morgan Chase), available at http://banking.senate.gov/public/files/OpgStmtDimonJPMorgan Chase040308.pdf ("[W]e could not and would not have assumed the substantial risks of acquiring Bear Stearns without the $\$ 30$ billion facility provided by the Fed. While we wanted to help, and I believe we were the only firm ultimately in a position to help, we had to protect the interests of our shareholders.").

291. See, e.g., The High-YIELD Debt MaRKET: InVESTMENT PERFoRMANCE AND ECONOMIC IMPACT (Edward I. Altman, ed. 1998); U.S. GeNERAL ACCOUNTING OFFICE, IsSUERS, PURCHASERS, AND PURPOSES OF High-YIELD, NON-INVESTMENT GRADE BONDS (1988); GLENN YAGO, JUNK BONDS: How High YieLD SECURITIES RESTRUCTURED AMERICA (1991) (discussing generally the subject of junk bonds).

292. CLOs More Concentrated in Shareholder-Friendly and Covenant-Lite Loans, FITCH RATINGS, Dec. 21, 2006, at 2; see also The Evolution of the U.S. Second-Lien Leveraged Loan Market-2006 Year-End Update, FITCH RATINGS, Jan. 17, 2007, at 1 [hereinafter The Evolution] (finding that a "substantial majority" of leverage deals involved leveraged loans). 
another example of how desensitization to leverage laid the foundation for this market. In the secondary market, nonbank lenders shaped both the design of the instrument and its trading practices. I conclude by considering how changes in the covenant practices for leveraged loans illustrate the provisional shift in bargaining power from lenders to borrowers, another factor that can promote speculative and Ponzi financing.

\section{Origination}

Leveraged loans are secured, floating-rate loans (typically priced off LIBOR) that are syndicated between commercial banks and nonbank lenders such as hedge funds and investment banks. Corporate borrowers may seek these loans for many reasons. Start-up companies may be unable to secure investment-grade ratings. ${ }^{293}$ Or cyclical businesses may need capital during a low point in their operations. ${ }^{294}$ Firms exiting bankruptcy or "fallen angels"--formerly investment-grade issuers that have been notched down-may be relegated here until the issuer's financial prospects improve. ${ }^{295}$ Leveraged loan issuance is cyclical in the direction that Minsky predicted-increasing during economic expansion and risk-taking. ${ }^{296}$ Issuance also correlates with trends in mergers and acquisitions and recapitalizations, two common forms of "shareholder-friendly" upstreaming. ${ }^{297}$

Like the junk bonds that financed the takeovers of the 1980s, leveraged loans rest on the assumption that lending at a subinvestment grade (albeit at a floating rate) is fine, so long as the rate reflects the default risk and is diversified in a portfolio. ${ }^{298}$ How borrowers, lenders, traders, and brokers came to think about leveraged loans reflects the semantic shifts that come with financial euphoria. The financial prefix "leverage" came to substitute for the harsher sounding "subinvestment grade" or, worse still, "junk" before the word "loan." Rather than thinking in terms of "credit supply" and borrower "demand for credit," the loans became "supply" for which (leveraged) investment demand competed, completing the semantic shift thanks to the growth of secondary markets. ${ }^{299}$ Indeed, even global financial regulators have adopted the custom of using "leveraged" as

293. The Evolution, supra note 292, at 2.

294. Id.

295. Id.

296. 'Several factors probably contribute to the cyclicality of leveraged debt issuance, including firms' more rapid growth rates during economic expansions (and consequent greater need for financing) and perhaps smaller levels of investor risk aversion during such times. The cyclical nature of LBO activity is another reason." COMM. ON THE GLOBAL FIN. SYS. WORKING GROUP, BANK FOR INT'L SETTLEMENTS, CBFS PAPERS No. 30, Private Equity and Leveraged Finance Markets 13 (2008) [hereinafter BIS, Leveraged FINANCE].

297. Id.

298. The corporate leveraged (or "high yield") market is made of several different types of credit facilities: senior unsecured high-yield bonds (43\%), first-lien bank debt (39\%), other forms of subordinated debt (11\%), senior secured high-yield bonds $(5 \%)$, and second-lien bank debt. STANDARD \& POOR'S, S\&P/LSTA LEVERAGED LOAN INDEX: A 10-YEAR RETROSPECTIVE 5 (2007) [hereinafter S\&P, RETROSPECTIVE].

299. See, e.g., YAGO \& MCCARTHY, supra note 64, at 20-29 (viewing leveraged borrowers as the "supply side" of the leveraged loan market and investor-lenders as the "demand side"). Indeed, even the concept of "structured finance" can be misleading, not only because it spans several distinct asset classes with little in common but also because it obscures the fact that our expectations about traditional debt instruments are much more settled and, in that sense, more "structured" than with new esoteric products that have never been seasoned through exposure to cyclical changes in financial markets. 
a substitute for "subinvestment grade" when it comes to these loans. ${ }^{300}$ These loans are another example of the kind of financial innovation that, according to Minsky, "regulates the pace of movement out of hedge and into speculative finance," and, presumably, Ponzi finance too. ${ }^{301}$ Much as the petro-liquidity of the 1970 s led to this type of investment demand, 302 this last leverage wave led to increasingly complex products that were further removed from their underlying cash flows. ${ }^{303}$

In 2006, the leveraged loan market represented about one-fifth of the overall corporate loan market and equaled about one-half of overall bond issuance. ${ }^{304}$ Had the trends in the first half of 2007 continued throughout the year, the volume of leveraged loans would have exceeded that of high-yield bonds. ${ }^{305}$ Leveraged loans have their own trade group - the Loan Syndications \& Trading Association (LSTA). LSTA promotes standardization of loan and settlement documentation, credit ratings for loans, Committee on Uniform Securities Identification Procedures (CUSIP) numbers for loans, and benchmark indices. ${ }^{306}$ Credit rating agencies helped to promote these loans by rating them, beginning with $S \& P$ in $2000 .{ }^{307}$ Within a few years, specialized recovery ratings had developed to supplement the projected default rate with estimates of how much an investor would recover in the event of default. ${ }^{308}$ Anticipating such ratings by several decades, Hickman's bond research had also considered the effective recovery rate on defaulted bonds. ${ }^{309}$

The arranger of the leveraged loan gets a fee of $1.5 \%-2.5 \%$ for putting the loan

300. See, e.g., BIS, LEVERAGED FINANCE, supra note 296 (using generally the term "leveraged" to refer to "subinvestment-grade").

301. MINSKY, UNSTABLE ECONOMY, supra note 130, at 212.

302. A promoter of the leveraged loan market traces its origin to the recycling of petro-liquidity in the 1970 s to sovereign borrowers (which culminated in the Brady Bond securitization of bank exposures into securities) and to the 1980s leveraged buyout boom. YAGO \& MCCARTHY, supra note 64, at 15-16.

303. For example, collateralized debt obligations which held "real" mortgages on the asset-side of their balance sheet gave way to synthetic collateralized debt obligations which were, in effect, contracts mirtoring the performance of "real" financial assets. RGE MONITOR, STRUCTURED FINANCE GLOSSARY 3 (2007) (showing how the market for securitized credit products moved from cash CDOs, to synthetic CDOS, to securitizations of the asset-backed securities themselves).

304. Richard W. Stewart, Collateralized Loan Obligations: A Primer, in LOAN SYNDICATIONS HANDBOOK, supra note 35, at 646, 658-61 (tracing the history of the CLO market). Between 1994 and 2005 both corporate bond and loan issuance increased, but the growth in loans outpaced that of bonds: bond issuance more than doubled from $\$ 306$ billion to $\$ 681$ billion while loan issuance quadrupled from $\$ 389$ billion to $\$ 1648$ billion. Allison A. Taylor \& Ruth Yang, Evolution of the Primary and Secondary Leveraged Loan Markets, in LOAN SYNDICATIONS HANDBOOK, supra note 35 , at $21,25$.

305. S\&P, RETROSPECTIVE, supra note 298, at 4 (explaining the composition of the index and its role in the leveraged loan market).

306. Steve Miller, Players in the Market, in LOAN SYNDICATIONS HANDBOOK, supra note 35, at 47, 73.

307. It also began to evaluate not just the likelihood of issuer default (as it always had) but also to estimate the actual amount that an investor could expect to recover in the event of a default. STANDARD \& POOR'S, A GUIDE TO THE LOAN MARKET 31-36 (2006). To arrive at a recovery rating for an issue, S\&P simulates the most likely default scenario. What distinguishes the recovery rating from the default rating is the recovery methodology's extensive analysis of "recovery factors" which require a close firm- and market-specific analysis of the cash flow behavior of an issue in the event of default. The methodology involves an ex ante projection of ex post recovery associated with credit underwriting standards. Id. at 31-32.

308. Steven Bavaria, Standard \& Poor's Loan Recovery Ratings, in LOAN SYNDICATIONS HANDBOOK, supra note 35 , at $526,528-29$.

309. Hickman, supra note 136 , at 2-4. 
together, more than the fees charged for investment-grade loans, which may have no arranger fees. ${ }^{310}$ Initially, leveraged loans included a revolving credit line and an amortizing term loan-so called "pro rata" tranches that bank investors preferred. ${ }^{311}$ While banks prefer to hold pro rata tranches, nonbank investors have tended to prefer junior tranches that did not amortize, had longer terms, and often lower security. ${ }^{312}$ So it has tended to be nonbank institutional investors who provided the riskier financing, a trend borne out by a finding in a 2006 federal review of syndicated lending that generally the credit quality of syndicated loans held by banks increased while that held by nonbanks decreased. ${ }^{313}$ Indeed, nonbank investors have become so dominant in these loans that "by early 2002, most [leveraged] loans were structured without an amortizing term loan component, and while the typical structure still included a revolver, it was usually a much smaller share of the overall package than would have been the norm in the past." 314

The Loan Pricing Corporation classifies as leveraged those loans with $\mathrm{BB}, \mathrm{BB} / \mathrm{B}$, and $B$ or lower ratings. ${ }^{315}$ Others use the loan's spread over a reference rate at the time the loan is made, typically a spread of between 125 to 275 basis points over a reference rate. ${ }^{316}$ Not surprisingly, leveraged loans correlate most closely as an asset class to highyield (junk) bonds, despite formal differences between the two. ${ }^{317}$ For example, most leveraged loans may be prepaid without penalty while high-yield bonds may not be callable by the issuer at all, or only occasionally, and then subject to a premium. ${ }^{318}$ These loans generally have a shorter term than high-yield bonds. ${ }^{319}$ These loans may also have more financial covenants than do high-yield bonds. ${ }^{320}$

The participation of commercial banks in originating leveraged loans has declined, in part because -of investments in regulatory capital to dispose of subinvestment grade assets. ${ }^{321}$ At the same time, nonbank investors became interested in leveraged loans

310. Lumpkin, supra note 47 , at 67.

311. The change made these loans riskier: "However, by early 2002 , most loans were structured without an amortising term loan component, and while the typical structure still included a revolver, it was usually a much smaller share of the overall package than would have been the norm in the past." Id. at 69 .

312. Scott Krase, Interplay with Other Capital Markets, in LOAN SYNDICATIONS HANDBOOK, supra note 35 , at 52, 52-61 (situating leveraged loans in the fixed income sector).

313. Joint Press Release, Bd. of Governors of the Fed. Reserve Sys., Fed. Deposit Ins. Corp., Office of the Comptroller of the Currency, \& Office of Thrift Supervision, Shared National Credit Data Reflect Good Credit Quality Performance, Large Increase in Credit Commitment Volume, and Small Rise in Riskier Deals (Sept. 25, 2006), available at http://www.federalreserve.gov/boarddocs $/ \mathrm{press} / \mathrm{bcreg} / 2006 / 20060925 / \mathrm{default}$.htm. See generally John Murchison, Warning Signs from Increases in Non-Performing Loans, 5 N.C. BANKING INST. 299 (2001) (explaining how federal banking agencies evaluate syndicated loans and noting a rise in nonperforming loans).

314. Lumpkin, supra note 47 , at 69.

315. YAGO \& MCCARTHY, supra note 64 , at 11-12.

316. Id. at 12 (comparing leveraged loan classification by Bloomberg, Standard \& Poor's, and Thompson Financial).

317. Id. at 40.

318. Gary D. Chamber \& Jolie Amie Tenholder, Converging Markets: Leveraged Syndicated Loans and High-Yield Bonds, COM. LENDING REv., Nov,-Dec., 2005, at 7.

319. Id.

320. Id. at 13.

321. BIS, LEVERAGED FINANCE, supra note 296, at 26. 
because of their high rates and secured status. ${ }^{322}$ For example, hedge funds became active in both the primary and secondary markets for leveraged loans, adding both liquidity and the risk that this liquidity will suddenly evaporate. ${ }^{323}$ It was nonbank demand for these loans that led to the concept of the "institutional loan" to refer to the funding provided by them. ${ }^{324}$ The S\&P/LSTA Leveraged Loan Index tracks only the institutional sector of the leveraged loan market, not the bank sector, suggesting that nonbank lenders are, indeed, changing the structure of credit, much as the Fed's decision to fund the Bear deal implies. 325

Both junk bonds and leveraged loans rest on financial logic that Braddock Hickman demonstrated in his early studies of borrowing cycles. Hickman's cycle study looked at bond issuance over the prior 50-year period of his study and found that the realized yield on the most senior secured obligations exceeded that of the least secured obligation in all but 2 of the 12 four-year blocks during which the study period was divided. ${ }^{326}$ In other words, bond issuers had paid too much for the senior secured financing given that lenders should have been willing to accept a lower rate of return in exchange for collateralized risk. And the yield spread between the most secured bonds and the lowest ranked unsecured securities was not as large as one would have expected. ${ }^{327}$ Both results seemed counterintuitive in that they did not reflect the idea that return should be proportional to financial risk. In fact, though, they were an early demonstration of financial

322. While in 1994 banks originated $71 \%$ of leveraged loans in the primary market and nonbank intermediaries bought only $29 \%$ of these assets, the proportions reversed in one decade: in the primary credit market of 2004, nonbank credit providers originated $78 \%$ of these leveraged loans and banks accounted only for $22 \%$. YAGO \& MCCARTHY, supra note 64 , at 19. However, the 2006 report of the Shared National Credit Review notes that nonbank credit providers provided only $14 \%$ of syndicated loan commitments. See BD. OF GOVERNORS OF THE FED. RESERVE SYS., FED. DEPosit INS. CORP., OFFICE OF THE COMPTROLler OF THE CURRENCY, \& OFFICE OF THRIFT SUPERVISION, 2006 SHARED NATIONAL CREDIT REVIEW 6 (2006) (discussing trends by type of financial entity). One source of the difference is that the Review targets both leveraged and unleveraged loans, but only those with a value of more than $\$ 20$ million and in which three or more regulated depository institutions participate. See YAGO \& MCCARTHY, supra note 64, at 19 (finding that bank purchases of leveraged loans decreased from $70 \%$ in 1994 to just over $20 \%$ in 2004).

323. Robert Milam, How to Trade Loans and the Strategies to Use, in LOAN SYNDICATIONS HaNdBOOK, supra note 35, at 403, 415-16 (noting the concern of other investors that hedge funds will "leave the loan space as quickly as they arrived when other markets provide more opportunities, dumping huge amounts of paper on the market in a hasty exit, and thereby driving down prices"); see also BIS, LEVERAGED FINANCE, supra note 296 , at 5 (stating that since the early part of the current decade the leveraged loan market has expanded to include nonbank investors).

324. Standard \& Poor's explained that:

Powered by strong demand, the pool of outstanding institutional loans grew to $\$ 400$ billion at the end of 2006 from $\$ 35$ billion at year-end 1997 . As a result, institutional loans grew to $41 \%$ of the overall universe of institutional and high-yield bonds, or $\$ 355$ billion of $\$ 953$ billion, from $28 \%$ a year earlier and from $25 \%$ at the end of $2004 \ldots$.

S\&P, RETROSPECTIVE, supra note 298 , at 4.

325. The loans which make up the Index must be syndicated U.S. dollar-denominated term loans for amounts of at least $\$ 50$ million and a term of one year and whose spread is at least 125 basis points over the LIBOR. Id. at 14.

326. W. Braddock Hickman \& Elizabeth T. Simpson, Statistical Measures of Corporate Bond FINANCING 340-47 (1960).

327. Id. 
diversification of risk through Markowitz's portfolio theory. ${ }^{328}$ And Hickman's findings about returns from high-yield instruments would help Michael Milken to promote junk bonds 30 years later. ${ }^{329}$ Moody's Investor Services revisited and corroborated Hickman's findings in 2004 when explaining how it distinguishes between investment-grade and speculative bonds. ${ }^{330}$

Between June and August 2007, leveraged loans faced their first major market liquidity crisis: origination dried up, loan products traded at a discount in the secondary market, and traders shorted loan indices. ${ }^{331}$ As activity slowed in the secondary market, these loans became stranded on the books of originating lenders, including banks. ${ }^{332}$ Surges in volume delayed trade settlement to an average of 17 days after the trade date. ${ }^{333}$ Banks with contractual duties to fund future leveraged loans found themselves choosing between paying "break-up fees" to walk away from the deal or to honor their commitments to originate the loans. ${ }^{334}$

\section{Secondary Markets}

In the secondary market for leveraged loans, buyers and sellers deal in previouslyissued loans, sometimes at a discount over the loan's par value based on changes in interest rates or the borrower's creditworthiness. The secondary market for these loans grew during the past decade. For example, the number of par value loans for which three or more market-makers made quotes increased ten-fold from 82 in 1998 to over 880 in $2007 .{ }^{335}$ Much of this trading happens right after the initial allocation of a loan (as investors adjust their holdings to reach their target), but, at the peak of the borrowing cycle, there had also been subsequent secondary trading, more so than with investment-

328. In research from the early 1950 s that was rewarded with a Nobel Prize, Harry Markowitz "observed that diversification reduces variance such that a diversified portfolio with an expected return is superior to an undiversified one with the same expected return." Robert J. Rhee, The Effect of Risk on Legal Valuation, $78 \mathrm{U}$. COLO. L. REV. 193, 228-29 (2007) (citation omitted). By comparing the return on a wide range of bonds together, Hickman was, in effect, considering a diversified portfolio.

329. See YAGO, supra note 291 , at $18-19$.

330. See Fons, supra note 34, at 4-6 (arguing that investment- and speculative-grade bond markets have developed separately, leading to unique practices).

331. See Leveraged Finance Quarterly Review: Third-Quarter 2007, FITCH RATINGS, Dec. 27, 2007, at 3-5 (discussing repricing of credit risk in the leveraged loan market and the use of a credit default swap index to short positions in leveraged loans).

332. The loss of secondary market liquidity had ripple effects upstream in the "pipeline": "Arranging banks found themselves either delaying loan placements or making a significant number of concessions to investors ... the credit crisis strained the banks' balance sheet capacity as they were forced to fund bridge loans on postponed loan syndications." Developments in the US Leveraged Loan and CLO Markets, FITCH RATINGS, Feb. 7, 2008, at 3 (suggesting that banks had a backlog of $\$ 200$ billion in leveraged loan commitments awaiting syndication).

333. Conversation with Allison Taylor, Director, Loan Syndication \& Trading Association (Nov. 14, 2007).

334. Justin Menza, Leveraged Loans Loom Large, BUS. WK., Feb. 22, 2008, at 1-2, available at http://businessweek.com/print/investor/content/feb2008/pi20080222_065212.htm (discussing reduction of commitments to fund leveraged loans by Credit Suisse and prospective charge-offs from funding commitments by Citigroup, Goldman Sachs, Merrill Lynch, and JP Morgan Chase).

335. BIS, LEVERAGED FINANCE, supra note 296, at 10. 
grade loans. ${ }^{336}$ Reporting of secondary loan transactions-along the lines of what is common in the equity markets-still does not occur systematically, so more is known about price quotes than about actual trades. ${ }^{337}$

As in the origination market, in the secondary market nonbank investors are more active than banks. ${ }^{338}$ As this market grew, investment banks that had traded these loans as brokers for the accounts of others began to take more proprietary positions in the loans. ${ }^{339}$ The same seems to be true for hedge funds that specialize in the credit market exposures. 340

Investment vehicles called "collateralized loan obligations" (CLO) played a key role in the secondary market by buying leveraged loans to collateralize the issuance of their own securities. Such CLOs may have accounted for over one-fifth of all secondary market demand for the loans. ${ }^{341}$ Compared with other forms of asset-backed securities like mortgage-backed securities and collateralized-debt obligations, CLOs tend to contain a more diverse set of receivables whose prepayment characteristics are harder to predict. ${ }^{342}$ Most frequently, CLOs buy leveraged loans based on one, two, or three month LIBOR. ${ }^{343}$ And CLOs seem to hold a disproportionate share of loans with fewer covenants $^{344}$ used for "shareholder-friendly" activities. ${ }^{345}$ Although modest, a secondary market in which interests in CLOs trade has also developed. ${ }^{346}$ Just as there are balance sheet and synthetic collateralized-debt obligations, CLOs may also be structured around a real portfolio of loans (so-called "balance sheet" CLOs) or hold an unrelated pool of securities as collateral but issue securities priced off of loan obligations (so-called "synthetic" CLO). ${ }^{347}$

336. Lumpkin, supra note 47 , at 73.

337. See YAGO \& MCCARTHY, supra note 64 , at 29 (describing a collaboration between the LSTA and LPC which gathers information about 4400 dealer quotes on more than 2000 facilities on a daily basis).

338. Nonbank investors tend to trade these loans more than banks: "[] nstitutional investors accounted for most of secondary market demand during the $1990 \mathrm{~s}$. . . although [highly-leveraged syndicated loans] account for a minority of the total amount of syndicated loans outstanding, they account for more than $80 \%$ of secondary market trading." Thomas \& Wang, supra note 226, at 304.

339. See YAGO \& MCCARTHY, supra note 64 , at 21 (showing the growth of nonbanks in the primary market, 1994-2004).

340. The volume of "credit-oriented" hedge fund assets increased six-fold to $\$ 300$ billion in 2005 , reflecting and intensifying the leverage cycle. Hedge Funds: The Credit Market's New Paradigm, FiTcH RATINGS, June 5, 2007, at 3. "Notably, this number excludes the multiplier effect of leverage and, therefore, understates the real amount of credit risk taken and the impact on trading volumes. . . prime brokers reported that credit strategies represented one of the fastest growth areas for hedge funds, outpacing equity-oriented growth of strategies." Id.

341. CLOs More Concentrated in Shareholder-Friendly and Covenant Loans, FITCH RATINGS, Dec. 21, 2006, at 1 [hereinafter CLOs More Concentrated].

342. Id. at 49 .

343. Stewart, supra note 304 , at $646,669$.

344. CLOs More Concentrated, supra note 341, at 2-3.

345. Developments in the US Leveraged Loan and CLO Markets, FITCH RATINGS, Feb. 7, 2008, at 5 (suggesting that CLOs acquired proportionately more loans for shareholder-friendly activities than the overall market).

346. Stewart, supra note 304 , at $646,664-65$ (estimating annual secondary market volume in CLOs to be more than $\$ 10$ billion).

347. Andreas A. Jobst, Collateralised Loan Obligations (CLOs): A Primer 34-47 (Dec. 2002) (unpublished manuscript), available at http://www.securitization.net/pdf/fmg_clo_100102.pdf (distinguishing between 
Repackaging leveraged loans into CLOs changes the total amount of leverage built into the product, hence increasing the product's exposure (and contribution) to financial instability. To begin with, the CLO is itself leveraged, typically at a debt-to-equity ratio of 10:1 to $12: 1{ }^{348}$ The CLO uses these leveraged resources to acquire leveraged loans issued by a borrower that is itself already leveraged, i.e., to the extent of any debt issued by the leveraged borrower. With these leveraged loans as collateral, the CLO then issues securities that may be more or less leveraged than the underlying leveraged loan collateral. ${ }^{349}$ And the investor who purchases a security issued by the CLO may borrow (through margin or other form of credit) to invest in the security. Each of the three different leverage "points" in the transaction-the debt burden of the leveraged loan issuer, the borrowing of the CLO, and the margin (or other) debt of the investor in the CLO-props up the price of the ultimate investment asset, i.e., the interest held by the investor in the CLO. Aggregate leverage supports the market liquidity for the product while, at the same time, exposing three borrowers to funding liquidity risk: the leveraged loan borrower, the CLO, and the leveraged investor. It is easy to see, then, how a product with so many layers of leverage can lose value quickly when speculative and Ponzi euphoria slows down, another illustration of the third liquidity axiom.

\section{Covenant Structure}

In general, a borrower's covenant practices vary with the respective funding market segments, which are differentiated by the degree of private contracting: public securities markets, the private loan market, and, in between, the private placement market. ${ }^{350}$ Higher-grade credits can use public debt markets to float issues with skeletal covenants that impose minimal constraints on the issuer's freedom of action. ${ }^{351}$ Investors in these issues take comfort in the issuer's credit-rating and in secondary markets in which to sell a position. ${ }^{352}$ In contrast, firms with a lower credit rating may have recourse only to private placement or bank loan markets in which lenders typically demand more covenants. ${ }^{353}$

balance sheet and synthetic CLOs).

348. Stewart, supra note 304 , at 646,651 .

349. For example, a senior position in a CLO represents a "deleveraging" with respect to underlying collateral while a junior position multiplies the leverage already built into the leveraged loans. $I d$. at 646,648 ("Senior tranches deleverage the asset class, whereas junior tranches and the equity tranche leverage both the credit risk and return embedded in the asset class.").

350. William W. Bratton, Bond Covenants and Creditor Protection: Economics and Law, Theory and Practice, Substance and Process 19 (Georgetown Law \& Econ. Research Paper, Paper No. 902910, 2006), available at $\mathrm{http} / /$ papers.ssrn.com/sol3/papers.cfm?abstract_id $=902910$. In the bank loan segment, lenders negotiate relatively complete contracts after examining the creditworthiness of the particular borrower. In the public securities segment, lenders accept less complete contracts because they rely on the borrower's "name" and the availability of secondary markets in which the lender may exit its position should the lender's holding preferences change. In between the bank loan and the public securities segments in terms of contractual completeness, the private placement segment involves debt contracts with some features of public debt contracts and the possibility of a secondary market later through Rule 144 filings. Id.

351. Id.

352. Id.

353. Understandably, then, the trade group for the issuer community - the Securities Industry and Financial Markets Association (SIFMA) - has objected to rating covenants on noninvestment grade debt. Letter from Mary Kuan, Vice President \& Assistant Gen. Counsel, Sec. Indust. \& Fin. Mkts. Ass'n, to Christina Padgett, 
The leverage boom reversed the distribution of covenants by market segment for both investment-grade bonds and leveraged loans, however. In investment-grade bonds, the frequency of covenants addressing a firm's debt-to-capitalization and debt-to-cash flow increased since 2001. ${ }^{354}$ And the frequency of any covenants limiting a firm's leverage has also been at its highest levels in the past four years of the decade ending in 2005. ${ }^{355}$ Moreover, in the public securities market-the segment of the three that has hitherto been willing to lend on the basis of the least-complete contracts-bondholder demand is growing for more specificity in contracting, for example by including in indenture agreements event-risk covenants that limit an issuer's leverage. ${ }^{356}$ At the same time, as noted earlier, covenants in lower-quality bonds have become less common. ${ }^{357}$ Both trends (increased covenant coverage and specificity in investment-grade and public underwritings and a reduction in covenants in lower-quality bonds) are counterintuitive, along the same lines of Hickman's counterintuitive findings about risk differentials in bonds. ${ }^{358}$ One effect of the volatility spike of summer 2007 and its fallout is that investors will become choosier about structural protections in leveraged loans that were overlooked in the earlier rush to lend and trade. This will likely be true not only upon issuance but also in the secondary market, where seasoned leveraged loans issued with few covenants will likely trade at a discount. 359

\section{B. Regulatory Implications}

So far, no court has held that leveraged loans are "securities" as defined in the federal securities laws. Nor has the SEC attempted to regulate the origination or trading of leveraged loans. Participants in the leveraged loan market are subject to liability under common law fraud and contract law but not under the registration and disclosure requirements of federal securities law. ${ }^{360}$ Were leveraged loans classified as securities,

Moody's Investors Serv. (Nov. 14, 2006) (on file with author). Because these securities are likely to involve some payment default, SIFMA notes, investors already scrutinize them more carefully and demand more covenant protection than they do for investment-grade issues. Id. at 3. Moreover, those who buy noninvestmentgrade debt have less need for third-party covenant assessment because they tend to be professional investors in the private placement market who rely more on their independent analysis of the default risks of the issue. Id. The SIFMA reaction illustrates Bratton's observation about a differential use of covenants based on the issuer's credit quality. See Bratton, supra note 350, at 19 ("Covenant usage varies across the segments, with incidence tending to follow the borrower's credit rating.").

354. Credit Quality Warning System Eroded by Disappearing Covenants, Fitch RATINGS, Aug. 9, 2006, at 4.

355. Id.

356. See Christina Padgett, Request for Comment on Moody's Indenture Covenant Research \& Assessment Framework, MoOdY's SpECial COMMENT (Moody's Investors Serv., New York, N.Y.), Sept. 2006, at 1, available at $\mathrm{http} / / \mathrm{www}$.moodys.com/moodys/cust/research/MDCdocs/13/2005800000428263.pdf (analyzing bondholder demand for event-risk covenants to limit leverage by issuing firms).

357. Id. at 5 .

358. See supra notes $246-54$ and accompanying text (explaining borrowing cycles and yield on the most senior secured obligations).

359. For example, during the summer credit slump of 2007 some covenant-lite loans dropped in price to 92 , which is still considered "par" trading since the convention in this market is to divide it into two tiers: "par" for everything trading at 90 to par and "distressed" for anything trading below that.

360. Tiziana M. Bason et al., Effects of the Legal Characterization of Loans Under the Securities Laws, in LOAN SYNDICATIONS HANDBOOK, supra note 35, at 85, $94-95$ (discussing concerns about disclosure and due 
the most natural exemption for them from registration would be that of Rule 144A under section 4(2) of the Securities Act of $1933 .{ }^{361}$ At present, there is no evil peculiar to the secondary market for leveraged loans calling for substantive regulation. Nevertheless, more disclosure about these loans might reduce our growing ignorance about credit markets. ${ }^{362}$ The major goal of doing so would be to impose minimum trade reporting duties on market participants in order to capture the information value of this market for public purposes. This way, regulators could capture some of the information that the leveraged loan markets generate that would be relevant to several basic questions over which financial market regulators have jurisdiction.

For example, some argue that the high yield market-which includes leveraged loans and high-yield bonds-has particular value as an indicator of financial or business cycle trends because of its particular sensitivity to credit downturns. ${ }^{363}$ Perhaps the same could be said about the repurchase market, as reflected in the problem with Bear's repo lenders. ${ }^{364}$ Similarly, noting the parallels between the corporate leverage waves of 1987 1989 and 2006-2007, a recent report by the Bank for International Settlements warns that the decline in leverage buyout volume since mid-2007 may portend corporate defaults, recession, and a general worsening of the corporate sector. ${ }^{365}$ If leveraged loans do act like a canary in a coal mine, then understanding origination and trading trends in leveraged loans might let regulators better anticipate changes in the real economy generally. And leveraged loans offer a window into the role of nonbank lenders both as originators of corporate credits and as market-makers for them in secondary markets. Exposing the SEC to data from what is essentially a capital market for credit would enhance the agency's knowledge base about the current state of credit markets. ${ }^{366}$

diligence issues in relation to antifraud provisions of securities laws).

361. Id. at $91-94$.

362. For example, in the case of Enron and related accounting scandals, legal and regulatory attention about the use of off-balance-sheet arrangements came too late. (And it is debatable whether the ensuing regulatory program-chiefly the Sarbanes-Oxley Act-rested on a solid foundation of how off-balance sheet arrangements fit into the larger funding market.) A secondary goal would be to promote the efforts already underway towards more standardization of loan terms and trading practices.

363. Yago and Trimbath noted:

The high yield market, and more generally the market for high yield financial innovations, represents a kind of "canary in the coal mine" for the economy as a whole .... Thus, when the high yield market stops singing, it signals the coming credit crunch that has the potential to trigger a recession.

YAGO \& TRIMBATH, BEYOND JUNK BONDS, supra note 137, at 126-27; see id. at 249 (discussing the explanatory value of high yield spreads over commercial paper, Treasury bills, and the Federal Funds rate).

364. See supra notes $110-12$ and accompanying text.

365. See BIS, LEVERAGED FINANCE, supra note 296, at 20 ("In this context, the sharp decline in LBO deal volumes seen since mid-2007 might well provide an early warning of a possible weakening of financing conditions for the broader corporate sector with implications for the real economy.").

366. The SEC already has substantive oversight of the municipal bond area through the Municipal Securities Rulemaking Board. A similar proposal to create a self-regulatory organization for the primary dealer market failed in 1992 when the Department of the Treasury and the Board of Governors of the Federal Reserve objected to the idea of SEC oversight over primary dealers, who play a key role in providing primary and secondary market liquidity for debt issuance by the Treasury. See DEP'T OF THE TREASURY ET AL., supra note 58, at 17-20 (explaining the primary dealer system). As a compromise, the agencies agreed that market surveillance of primary market dealers would adequately further the respective interests of the agencies. $I d$. at 
Creating a limited-purpose self-regulatory organization (SRO) in order to conduct minimum market surveillance of the leveraged loan market is one way of obtaining this data. Historically, SROs have included only securities exchanges and other industry "utilities," like clearing agencies, which participated in markets for financial instruments meeting the legal definition of a "security." 367 Given the scope of legal reforms being considered in connection with the Treasury Blueprint, though, a novel approach to leveraged loans might be in order given their value as a source of knowledge about the current credit market. The obvious candidate for SRO status would be the LSTA.

\section{MODELING LEVERAGED LIQUIDITY}

The Treasury, Congress, and various trade groups have begun proposing legislative fixes to the credit market. In March, the President's Working Group on Financial Markets responded to the credit conditions from 2007 with a comprehensive policy statement recommending a variety of changes to credit underwriting, rating, and risk management. ${ }^{368}$ The Treasury Blueprint came out soon thereafter. One factor that will determine whether reforms work is whether they address the liquidity dynamics that this market break brought to light. To that end, let me suggest some changes to our financial models. For regulators and academics, this means paying more attention to market structure-and dynamic shifts to it - when thinking about regulatory processes. For firms, it means internalizing extreme liquidity events that tax firm and market liquidity in risk management models.

\section{A. From Models to Markets}

Part of the current problem is that two competing approaches to modeling credit markets developed after the New Deal: heavily empirical models that generalized inductively based on data-rich observation and, in contrast, elegant mathematical models that generalized deductively through simplifying assumptions about markets. The two roads diverged and empirical models-of which Hickman's bond issuance research is a prime example-became the road not taken.

Soon after Hickman published his bond research in the 1950s, Merton Miller and Franco Modigliani published an influential article on the capital structure of firms that epitomized the deductive finance model, signaling its future dominance. ${ }^{369}$ The article refuted the common-sense intuition that borrowing reduced the cost of capital to the firm: as the firm borrows more, so went the proof, the costs of both its debt and equity increase because both creditors and shareholders demand a higher return for investing in a firm

$22-23$.

367. See Securities Exchange Act of 1934 §3(a)(28), 15 U.S.C. $\S 77 \mathrm{c}$ (2000) (defining SRO).

368. President's Working Group on Fin. Mkts., Policy Statement on Financial Market DEVELOPMENTS (2008).

369. Four years after Minsky completed his thesis, Franco Modigliani and Merton Miller published their mathematical proof that the value of a firm is independent of its financing structure. See generally Modigliani \& Miller, supra note 135 (proposing a definition of the cost of capital). In this way, the Miller-Modigliani hypothesis "substituted a tool of analysis for the problem," taking the question of balance sheet financing out of mainstream economics. Toporowski, supra note 133, at 9. 
that has become more leveraged and, therefore, riskier. ${ }^{370}$ These self-regulating price alterations would balance each other out such that adjustments on the right-hand side of the balance sheet (the side that reflects financing) would not affect firm value. ${ }^{371}$ Hence, financing structure was "irrelevant" because what was going on in the right-hand side of its balance sheet could not-as a theoretical matter-influence the value of the firm, which depended on the firm's assets.

Like any deductive model, the Modigliani-Miller (M-M) approach works only within the four corners of its modeling assumptions: the absence of income taxes, equal borrowing costs to firms and individuals, efficient markets, and perfect markets. ${ }^{372}$ Although it is not perfectly clear, the model also seems to assume fixed-rate debt. ${ }^{373} \mathrm{~A}$ footnote in the M-M article does allude to firms' funding liquidity but it is not central to the argument. ${ }^{374}$ As noted, these simplifying assumptions point to what would affect firm value, i.e., everything that has been assumed away. By assuming away the realities of how firms actually fund themselves, the approach helped to sideline inquiry into how real firms manage their balance sheets. ${ }^{375}$ (So what is most important in the liquidity account of corporate leverage markets from Part II would also get assumed away. ${ }^{376}$ ) If the M-M assumptions were true, then finance professionals would have "all but disappeared, taking with them corporate finance as an area of scholarship and teaching. But the assumptions are not accurate, work is booming, and the discipline is flourishing." 377

Not only do these deductive models fail to reflect actual markets but, "indeed, a model can induce a market." 378 It does this by contributing to a market-wide shift in

370. See generally Modigliani \& Miller, supra note 135.

371. Id.

372. Peter H. Huang \& Michael S. Knoll, Corporate Finance, Corporate Law and Finance Theory, 74 S. CAL. L. REV. 175, 177-78 (2000). It is an example of the old saw: "How does an economist change a lightbulb?" "Assume a ladder."

373. See Modigliani \& Miller, supra note 135, at 261, 268 ("All bonds (including any debts issued by households for the purpose of carrying shares) are assumed to yield a constant per unit of time."). Elsewhere in their paper, Modigliani and Miller note that, in fact, a range of interest rates exist. Id. at 273 ("In existing capital markets we find not one, but a whole family of interest rates varying with maturity, with the technical provisions of the loan and, what is most relevant for present purposes, with the financial condition of the borrower." (citation omitted)). In the context of the discussion, though, these would seem to be a range of fixed interest rates.

374. The observation arises after Modigliani and Miller note that what typically makes borrowing more difficult for firms is not higher interest rates but, instead, "increasingly stringent restrictions imposed on the company's management and finances by the creditors [that can result] in a complete inability to obtain new borrowed funds, at least from the institutional investors who normally set the standards in the market for bonds." Id. at 273 n. 17 .

375. As Huang \& Knoll note:

The explanatory power of the M\&M [Modigliani \& Miller] Theorem comes from turning it upside down: If capital structure can affect the value of the firm, it must work through one or more of the four M\&M assumptions. That is to say, the only ways that capital structure can increase value are by lowering taxes, providing access to cheaper borrowing, releasing valuable information, or improving cash flow. We call this idea the Reverse M\&M Theorem.

Huang \& Knoll, supra note 372, at 179 (citation omitted).

376. My liquidity account of corporate leverage emphasizes borrowing costs and cash flow, two of the dimensions that Huang \& Knoll point out are assumed away. $I d$.

377. Id. at 191 .

378. The financial model creates investment demand, which leads to investment supply: 
attitudes towards risk and its management. As has been noted about the Black-Scholes option pricing model: "Black-Scholes is no longer just a model; it has evolved into a climate of opinion about a certain kind of financial risk." ${ }^{379}$ Like the M-M approach, the Black-Scholes model rests on mathematical logic that is inaccessible to the mathematically-uninitiated. ${ }^{380}$ Black-Scholes may have contributed to the recent leverage boom by failing to reflect how asset prices will really behave in an extreme downward turn in prices. ${ }^{381}$

Nevertheless, this deductive approach to corporate finance took hold in the academy, so much so that in 1990, Merton Miller received the Nobel Prize for his work on capital structure. In his acceptance speech, Miller recalled the capital irrelevancy hypothesis when he observed that there was no such thing as an "overleveraged" firm because its cost of debt and equity capital would simply adjust to reflect its risk. ${ }^{382}$ That may be the case inside the model of a single firm, but when leveraging practices could affect the finance sector as a whole-as Minsky suggested about speculative and Ponzi borrowing--then the effects of the firm's borrowing extended more widely. In Ronald Coase's acceptance speech the following year for the same Nobel prize that Miller had received, he warned against assuming away the economic realities of firms and markets, arguing that "detailed knowledge of the economic system" was necessary to avoid having "[w]hat is studied [be] a system which lives in the minds of economists but not on earth." 383 Coase's award suggested growing appreciation for the value of more empirically grounded arguments about corporate leverage. Hickman, Minsky, and, certainly, this Article strive to be in that latter vein, one that emphasizes market structure

"The model created markets," [hedge fund manager John] Seo says. "Markets follow models. So these markets spring up, and the people in them figure out that, at least for some of it, BlackScholes doesn't work. For certain kinds of risk-the risk of rare, extreme events-the model is not just wrong. It's very wrong. But the only reason these markets sprang up in the first place was the supposition that Black-Scholes could price these things fairly."

Michael Lewis, Inside Wall Street's Black Hole, PORTFOLIO, Mar. 2008, at 132.

379. Id.

380. Id. at 130 .

381. Id.

382. Merton H. Miller, Leverage: Acceptance Speech for The Sveriges Riksbank Prize in Economic Sciences in Memory of Alfred Nobel (Dec. 7, 1990), in 1990 ECON. SCI. 291, 298-300, available at http://nobelprize.org/nobel_prizes/economics/laureates/1990/miller-lecture.pdf (arguing that market forces "self-correct" the supply and demand for leverage endogenously through interest rates).

383. Ronald H. Coase, The Institutional Structure of Production, Acceptance Speech for The Sveriges Riksbank Prize in Economic Sciences in Memory of Alfred Nobel (Dec. 9, 1991), available at http://nobelprize.org/nobel_prizes/economics/laureates/1991/coase-lecture.html. Coase won the Nobel Prize for economics in 1991, the year after Merton Miller, whose work epitomizes the deductive finance that underwrites financial models. Coase's acceptance speech emphasized his concerns about deductive modeling. To make economics more earthly, Coase's The Nature of the Firm stressed that the "transaction costs" of organizing production in one way or another would ultimately come to determine the structure of firms and, hence, the industrial structure of production. Id. Analyzing transaction costs figured too in The Problem of Social Costs, this time to evaluate how they influenced the efficacy of law, itself a source of transaction costs. Id. Thinking about these costs as an independent variable has found its way into legal scholarship, thanks more to The Problem of Social Costs than to The Nature of the Firm. Id. Coase gave two reasons for why scholarship received the former article more warmly than the latter: Kuhnian resistance to paradigm change and the very absence of the empirical knowledge about industrial production on which his work insisted. $I d$. 
as an empirical reality.

When testifying before the Senate Banking Committee about the Bear deal, SEC Chairman Cox gave an important example of a financial assumption that had to be revised in light of the liquidity turbulence: high quality collateral could induce a lender to deal with a risky borrower. ${ }^{384}$ As noted earlier, what had led the Fed to intervene in Bear was the unwillingness of lenders to accept high quality government securities as collateral for loans in the secured repurchase agreements. ${ }^{385}$ Cox was, in effect, confronting the actual market structure of liquidity rather than the modeling assumptions that had been amply supported until then. (The next section reports on other major corrections of modeling assumptions about firm and market liquidity.)

More generally, market structure matters because, as has been observed about the quality of trade execution for retail investors in equities, the market is its market structure because it is this structure that determines the outcomes for buyers and sellers and defines the dynamics that regulators must address. ${ }^{386}$ Thinking in terms of market structure is more common when law requires it, for example in telecommunications, antitrust law, and the federal securities market. Credit markets have a structure too, but the divide between bank and securities regulation creates a regulatory gap. True, the SEC has a statutory mandate to look after the national capital market system, but it has focused on equity markets, even though more debt than equity is raised in capital markets. ${ }^{387}$ Banking regulators do consider the market structure of banking; but regulation has yet to catch up with current corporate lending practices. ${ }^{388}$ Indeed, the financial sector may be

384. Before this recent set of crises, it had seemed logical to assume that collateral of sufficient quality would make a lender indifferent to a borrower's own risk:

But what neither the [SEC's consolidated supervised entities] regulatory approach nor any existing regulatory model has taken into account is the possibility that secured funding, even that backed by high-quality collateral such as U.S. Treasury and agency securities [e.g., repurchase agreements], could become unavailable. The existing models for both commercial and investment banks are premised on the expectancy that secured funding, albeit perhaps on less favorable terms than normal, would be available in any market environment.

Cox Testimony, supra note 43.

385. See supra notes 110-12 and accompanying text.

386. See generally Lawrence E. Mitchell, Structure As an Independent Variable in Assessing Stock Market Failures, 72 GEO. WASH. L. REV. 547 (2004). The equity markets that he analyzes include the physical and over-the-counter trading mechanisms in which buyers and sellers exchange equity securities. See id. at 560-63 (listing the major stock exchanges, securities associations, and alternative trading systems where equities trade). Mitchell argues that focusing on market structure would better reveal the effect of market dispersion on competition and its effects on execution quality for retail investors. Id. at 563-68 (focusing on order routing and execution of equity trades by retail investors).

387. Congress gave the SEC authority to analyze the national structure of capital markets in the National Market System Amendments of 1975, some 40 years after establishing the SEC. Dale A. Oesterle, Has the SEC Exceeded Its Congressional Mandate to Facilitate a "National Market System" in Securities Trading, I N.Y.U. J.L. \& BUS. 613, 617-29 (2005) (analyzing the history and context of the National Market System Amendments); see Corinne Bronfman, Kenneth Lehn, \& Robert A. Schwartz, Market 2000: The SEC's Market 2000 Report, 19 J. CORP. L. 523 (1994) (describing the enactment of the National Market System Amendments of 1975, which identified specific aspects of market structure policy on which the agency should concentrate). Congress and the SEC disagreed over what the agency's role in market structure should be: Congress favored a more substantive role in promoting competition while the SEC preferred to analyze and influence market structure through requiring disclosure about firms and products. Id. at 528-29.

388. Since passage of the Bank Merger Act of 1960 , Federal Reserve member banks have held an annual 


\section{changing too rapidly to freeze in any single regulatory model. 389}

In part, this is because we still think about the liquidity dynamics of financial intermediaries in terms of a fading distinction between, on the one hand, broker-dealer investment banks regulated by the SEC and, on the other hand, insured depository institutions under the jurisdiction of federal and state banking regulators. The old distinction about liquidity made sense when banks and broker-dealers served fundamentally different functions, but it makes less sense now that the balance sheets of banks and broker-dealers resemble each other more closely. ${ }^{390}$ Bank regulators have long been the citadel of funding liquidity. ${ }^{391}$ In contrast, the SEC's regulatory capital rule for broker-dealers (net capital rule) has always taken market liquidity into account by insisting that broker-dealers hold liquid assets with a ready market. ${ }^{392}$ Now, though, the SEC's capital rules are changing somewhat in the direction of the banking approach to funding liquidity and capital. ${ }^{393}$ And other securities regulators are also grappling with how borrower and market liquidity interact for their securities firms. ${ }^{394}$ An impressive

conference to report on trends in U.S. banking structure. See, e.g., Fed. Reserve Bank of Chi., A Brief History of the Conference on Bank Structure \& Competition, http://chicagofed.org/news_and_conferences/conferences and_events/2005_bank_structure_history.cfm (last visited Feb. 17, 2009) (describing the Federal Reserve Bank of Chicago's yearly conferences).

389. Alastair Clark, Advisor to the Governor, Bank of Eng., Analytical Models of Financial Stability, Remarks at the Cass Business School 12-13 (Mar. 28, 2007), available at http://www.bankofengland.co.uk/ publications/speeches/2007/speech307.pdf ("[T]here is one further difficulty [in modeling financial stability]namely that the structure of the financial sector is changing and arguably changing faster than that of any other sector in the economy.").

390. The convergence between the two business models shows up on the balance sheet: "Securities firms are holding more loans and other less liquid assets, while bank assets are becoming more liquid as the rather strict reliance (in some jurisdictions) on banks as the means for transforming short-term, liquid funds into longer term loans gives way to more market-based financial intermediation. . . A number of policy questions do arise, however, as loan markets become more transactional in nature and as relatively more of the intermediation of credit or pricing of credit risk takes place in the market." See Lumpkin, supra note 47, at 79.

391. One good plain-English source on liquidity management in banks--although its implications extend to any firm facing changes in its funding provider-is the U.S. Comptroller of the Currency's handbook for national banks on liquidity. LIQUIDITY HANDBOOK, supra note 41 , at 1.

392. Steven L. Molinari \& Nelson S. Kibler, Broker-Dealers' Financial Responsibility Under the Uniform Net Capital Rule-A Case for Liquidity, 72 GEO. L.J. 1, 18-22 (1983) (emphasizing the centrality of mandating broker-dealer investment in liquid assets in the net capital rule).

393. For example, the SEC now allows complex financial firms to use what are essentially banking models of risk management to evaluate their regulatory capital requirements as part of the agency's consolidated supervision program. Erik Sirri, Director, Div. of Mkt. Regulation, U.S. Sec. \& Exch. Comm'n, Testimony Concerning the Consolidated Supervision of U.S. Securities Firms and Affiliated Industrial Loan Corporations Before the Sen. Comm. on Banking, Housing, and Urban Affairs (Oct. 4, 2007) ("The [consolidated supervision] program provides consolidated supervision to investment bank holding companies that is designed to be broadly consistent with Federal Reserve oversight of bank holding companies.").

394. Technical COMm., Int'L ORg. OF SeC. COMm'ns, SOUNd Practices for the Management of LIQUIDITY RISK AT SECURITIES FIRMS (2002) [hereinafter SOUND PRACTICES]. Reflecting the convergence at the regulatory level between risk management approaches for commercial and investment banking, this document applies a traditional commercial banking approach to liquidity management to securities firms as reflected in the Comptroller of the Currency's Liquidity Handbook, discussed supra at note 41 . The interplay between the borrowing security firm's own liquidity and that of asset markets shows up in several points. For example, it is asset market liquidity that determines the amount of "cash obtained [by the borrower] from the maturation, sale of assets or their use as collateral in secured funding (particularly repurchase agreements)." SOUND PRACTICES, supra, at 3. Similarly, the borrower's liquidity is in peril when "the assets on a firm's books 
and encouraging exception to this is a recent report by financial market regulators from the United States, the United Kingdom, France, Germany, and Switzerland on how financial firms managed the credit market events since the summer of 2007 by emphasizing the need for financial firms to better manage their funding liquidity. ${ }^{395}$ It is a prime example of regulators staying on the frontier of firm liquidity management.

\section{B. Internalizing Extreme Liquidity Events Into Risk Management (and Then Back to Models)}

The losses from the summer of 2007 took financial firms by surprise because their risk management models had failed to anticipate the scope and depth of the losses. Yet noticeably absent from the Treasury Blueprint was any serious emphasis on one of the most important drivers of the credit turbulence: that the financial models used for investment and regulation had done a poor job of suggesting the size and nature of the current credit contraction. As Fed chairman, even Alan Greenspan conceded (although not in terms that Main Street would understand) that financial models may not adequately take into account the extreme events that give rise to liquidity panics or the panics themselves. ${ }^{396}$

We have crossed the Rubicon in terms of abandoning the gold standard (which would constrain leverage and leveraged liquidity), so my point is not that leveraged liquidity can be avoided. Quite the contrary, it is a mainstay of financial capitalism, so it deserves better financial and legal modeling. The direction in liquidity risk management is towards more comprehensive measures of firm liquidity. 397 Moreover, internalizing firm and market liquidity risks in a firm's risk management is in line with the trend in governance at public corporations towards comprehensive, enterprise-wide risk

may not be sufficiently liquid to provide cash should the need arise." Id. Also, the report's discussion of valuation "haircuts" for collateral is one attempt to make sure that the firm's estimated valuation of an asset will support rather than compromise the firm's liquidity. Id. at 15-16.

395. SENIOR SuPERVISORS GROUP, OBSERVATIONS ON Risk MANAGEMENT PRACTICES DuRING THE RECENT MARKET TURBULENCE 3, 10-12 (2008).

396. Alan Greenspan, Chairman of the Fed. Reserve, New Challenges for Monetary Policy: Remarks Before a Symposium Sponsored by the Federal Reserve Bank of Kansas City (Aug. 27, 1999), available at http://www.federalreserve.gov/BOARDDOCS/SPEECHES/1999/19990827.htm. This is what began to happen during the summer of 2007 in leveraged loans and credit markets generally:

Probability distributions that are estimated largely, or exclusively, over cycles excluding periods of panic will underestimate the probability of extreme price movements because they fail to capture a secondary peak at the extreme negative tail that reflects the probability of occurrence of a panic .... Under these circumstances, fear and disengagement by investors often result in simultaneous declines in the values of private obligations ... . Consequently, the benefits of portfolio diversification will tend to be overestimated when the rare panic periods are not taken into account.

Id.

397. INST. OF INT'L FIN., PRINCIPLES OF LIQUIDITY RISK MANAGEMENT 40 (2007). Drafted by a committee of treasury management officers from 40 of the largest globally active finance firms, the report encourages thinking in terms of a firm's "integrated liquidity position." $1 d$. The report recommends that firms conduct scenario analysis using both firm-specific events and market-wide events that may influence the firm's liquidity. Although not mentioned in the IIF report, detecting the early warning signs of liquidity risk is key as well. LIQUIDITY HANDBOOK, supra note 41 , at 6-8. 


\section{management. ${ }^{398}$}

Insofar as it is financial models that contribute to speculative and Ponzi investment, closing the reality gap in these models might limit euphoric investment or at least better forecast the downside. ${ }^{399}$ We already knew that these deductive models did not reflect the "fat tail" distributions associated with extremal events (although the positive fat tails meant bumper profits on the upside), but the shape of the omission did not become clear until financial losses mounted. In particular, models did not anticipate that asset market liquidity might shrink drastically. ${ }^{400}$ More generally, any risk management models that uses the "mid-price" between the bid and the ask quote to estimate the price at which a hypothetical transaction will clear may underestimate the real liquidity risk of a trade. ${ }^{401}$ This is so because when markets are moving against an investor's position, the investor may realize less than the mid-price. ${ }^{402}$ Because of the link established earlier between market and firm liquidity, these defects in anticipating market liquidity can reduce the firm's ability to manage its own liquidity.

Another general shortcoming of the models was that they relied on historical data about seasoned products and previous credit trends that had been less severe. ${ }^{403}$ Structured credit products like collateralized debt or loan obligations had never been exposed to a major market downturn, so models failed to predict how they would behave as market liquidity receded. ${ }^{404}$ Moreover, while these econometric models did analyze how an adverse credit event unique to the firm (say a downgrade by a credit rating agency) would impact the firm's liquidity, these models failed to anticipate conditions that might affect the finance sector as a whole. ${ }^{405}$ Nor did they predict that, as the credit market worsened, even large finance firms would face increased borrowing costs (including from each other as their respective judgments of each other's riskiness

398. See Betty Simkins \& Steven A. Ramirez, Enterprise-Wide Risk Management and Corporate Governance, 39 LOY. U. CHI. L.J. 571, 586-94 (2008) (analyzing and advocating for risk management and corporate governance that looks at risk to a firm in organic terms). The authors see the liquidity crisis that began in 2007 as a consequence, in the aggregate, of inadequate risk management by firms. $I d$. at 590 .

399. The model is entrenched: '“If you try to attack [Black-Scholes],' says one longtime trader of abstruse financial options, 'you're making a case for your own unintelligence.' The math was too advanced; the theorists too smart; the debate for anyone without a degree in mathematics was bound to end badly." Lewis, supra note 378 , at 132 .

400. See SENIOR SUPERVISORS GROUP, supra note 395, at 11. It is another expression of the failure to properly reckon with foreseeable financial instability: "In particular, banks had made assumptions about the asset market liquidity of certain structured products, [asset-backed commercial paper] and loan books that proved to be overly optimistic .... It had not been anticipated that the liquidity of such markets would evaporate ...." BASEL COMM., supra note 56, at 12.

401. Anil Bangia et al., Modeling Liquidity Risk, with Implications for Traditional Market Risk Measurement and Management 3 (Wharton Fin. Insts. Ctr., Working Paper No. 99-06, 1999). "Marking to market therefore yields an underestimation of the true risk in such markets, because the realized value upon liquidation can deviate significantly from the market mid-price." $I d$.

402. Id.; see also BIS, LEVERAGED FINANCE, supra note 296, at 3 ("The recent market turmoil has exposed challenges to loan valuations based on market prices. For example, market prices of leveraged loans and loan indices may deviate from their economic fundamentals during periods of market stress if liquidity premia rise substantially.").

403. See SENIOR SUPERVISORS GROUP, supra note 395, at 14, 16.

404. Id. at 14 .

405. Id. at 11 . 
increased), compromising their own funding liquidity. 406 In general, then, risk management models must better account for extreme liquidity events, a point beginning to be emphasized by federal and international banking officials. ${ }^{407}$

The next generation of financial models will have the benefit of the present credit crunch and the ensuing unwinding of positions to better reflect the impact on a borrower's liquidity of market liquidity and, vice-versa, the impact on market liquidity of borrower liquidity in the aggregate. The Liquid Asset Pricing Model (LAPM) is one attempt to reflect how market liquidity would impact the price that an asset will fetch. ${ }^{408}$ Though based on the Capital Asset Pricing Model (CAPM), the LAPM uses assumptions about corporate demand for liquidity (rather than consumer demand as does the CAPM) to model the liquidity preferences of institutional borrowers and lenders more finely. 409 This seems to be a step in the right direction.

\section{CONCLUSION}

Financial hubris most recently took the form of liquidity euphoria, a more specific expression of general financial euphoria, intensified by our proneness to the charms of financial innovation. ${ }^{410} \mathrm{I}$ am guilty of this same proneness, so one reason for this Article was to subject financial curiosity to more rigor.

Let me recapitulate before concluding. This Article had two major goals-one methodological and the other substantive. My main methodological point was that particular firms, transactions, instruments, and market practices (as well as their history) matter. ${ }^{411}$ I focused on leveraged loans because they are a paradigm case of market structure shifts toward speculative and Ponzi finance and the new liquidity dynamics of credit, especially now that secondary markets for credit influence the very origination of

406. Id.

407. Donald L. Kohn, Vice Chairman, Bd. of Governors of the Fed. Reserve Sys., Money Markets and Financial Stability: Speech at the Federal Reserve Bank of New York and Columbia Business School Conference on the Role of Money Markets 3 (May 29, 2008), available at http://www.federalreserve.gov/ newsevents/speech/kohn20080529a.htm. As noted recently by a senior Federal Reserve official:

Recent developments suggest that market participants must thoroughly reassess the marketliquidity assumptions that underlie their existing risk-management practices. The scope and duration of disruptions to market liquidity that we have experienced since last summer have greatly exceeded what market participants, prudential supervisors, and central banks thought likely or even possible. The implications are quite broad and significant. In general, in determining the appropriate size of their liquidity buffers (their holdings of unencumbered liquid assets or their access to very stable sources of funding), market participants must plan for the possibility of moresevere liquidity shocks.

Id.

408. Jean Tirole, Liquidity Shortages: Theoretical Underpinnings, Fin. STABILITY REV., Feb. 2008, at 53, 59-60. The model is set out in mathematical form in B. Holmström \& Jean Tirole, LAPM: A Liquidity-Based Asset Pricing Model, 56 J. Fin. 837 (2001).

409. See Tirole, supra note 408 , at 59-60.

410. See supra notes $22-23$ and accompanying text.

411. As economist John Kenneth Galbraith noted about finance: "There can be few fields of human endeavor in which history counts for so little as in the world of finance." GALBRAITH, supra note 140, at 12; see also id. at 1-17 (arguing that collective psychological mechanisms contribute to financial crises by, inter alia, discouraging criticism of financial speculation). 
credit. These loans are a prism into the more generalized euphoria in which borrower demand became loan supply and leveraged took the place of the less sanguine "junk" moniker. In this Article, repurchase markets were another example of a signal instrument. Historically, repurchase markets for collateralized lending gave financial intermediaries access to both asset and borrower liquidity in a market that was, arguably, safer than even investment-grade commercial paper. To see confidence recede in the repurchase market, as it began to with Bear, is significant. Inductive methods (like case studies) that provide a grittier account of how firms finance themselves might lead to better governors for financial risk-taking.

My main substantive goal was to propose a conceptual framework for liquidity dynamics that ought to inform regulation and private risk management. In particular, the dynamic feedback loops between borrowing, a borrowing firm's liquidity, and the market liquidity for a firm's traded liability deserve more scrutiny. To that end, I proposed three liquidity axioms to thematize the notion of leveraged liquidity. First, a firm can convert the liquidity of its assets into the firm's own liquidity, so long as a secondary market cooperates. Second, frothy liquidity in the secondary market for a firm's liabilities (as opposed to its assets) may not reflect the firm's own overall liquidity or, even, the ongoing credit quality of that particular liability, especially during a leverage cycle in which firms borrow euphorically. Third, insofar as a firm's demand for financial assets is financed by borrowing, that firm's decision to shore up its own financial position by borrowing less may - in the aggregate with other like-acting firms-send shock waves through the secondary market as demand dries up for these assets, including structured credit products.

Some tentative conclusions are in order about these axioms. First, the growth of floating-rate borrowing by corporations merits attention because rising rates increase the liquidity risk of borrowers, despite the promises of risk dispersion suggested by financial derivatives and risk management instruments like credit default swaps. Because borrowers follow the herd, market-wide shifts in borrowing terms are properly regulatory concerns. Second, nonbank firms are now special too, insofar as they have become active (and, at times, dominant) in originating and trading corporate credit. Third, when beauty contests in the secondary market turn ugly, loans of questionable quality can get stranded on the books of lenders, turning lenders who should be liquidity providers into liquidity junkies, thereby activating the firm-market liquidity loop downward.

Again, I spoke in terms of leveraged liquidity to point out that when liquidityeither in a borrower or in a market-is leveraged through borrowing (and that way encumbered with other claims), it can engender financial instability, even as it seems to be doing the opposite by facilitating exchange. I chose Minsky's theory because it internalizes both the upside and the downside of leverage cycles while avoiding financial euphoria or a knee-jerk hostility to financial risk and institutions that is common in some critical accounts of financial capitalism. Starting from the assumption that borrowing leads to financial instability may seem disconcerting, but it is a truth that ought to be reflected in modeling assumption. And if starting from the premise of financial instability could raise the bottom when the financial cycle turns for the worse (as it is doing now), then being more accurate in our forecasts is worth the theoretical discomfort. 